ORNL/ENG/TI:-2

\title{
NUCLEAR RELIABILITY ASSURANCE DATA SOURCE GUIDE
}

\section{ROTICE}

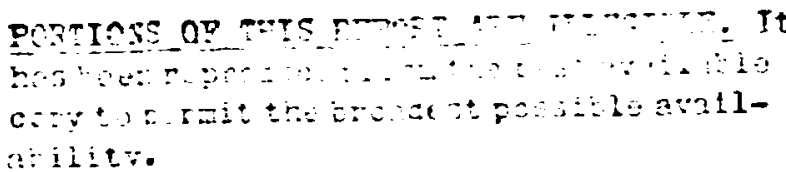

$$
\text { pistive }
$$


Pr :ied a the Unted States uf America Avallable from Narond Techrical Information Service

L.S Department of Cummerce

5285 r.m: Roval Rodd. Soringfield. 'Jirgin!a 22161

Pr.ce Pricted Cocy \$5 50. Nicrofiche $\$ 225$

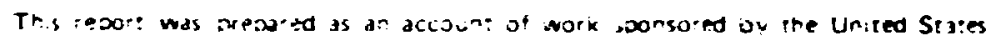

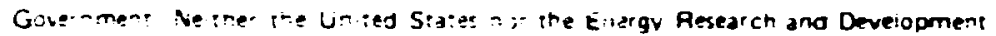

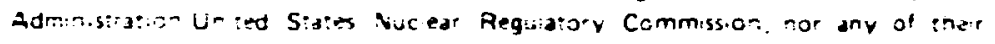

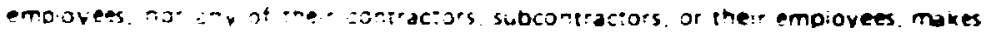

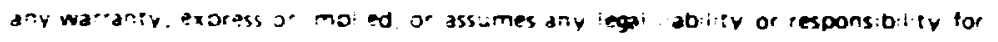

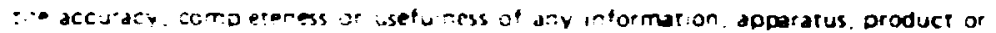

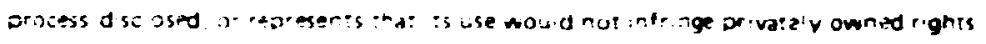


coneract is. b-7:05-eng-26

E.STINERING DiUSIOA

NLCLEAR RELLABILITY ASSLRATCE

DATi SOLRCE GLIDE

Dote Rublished: Noventer 1976

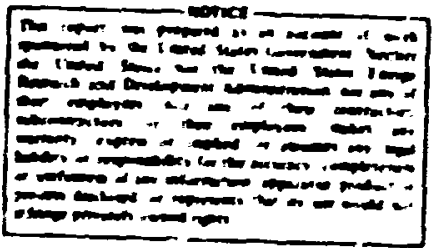

OAK RIDGE NATIONAL LABORATORY

Oak Ridge, TEnnzssee 37830

operated by

LNION CARBIDE CORPORATION

fCr the

ENERGY RESEARCH AND UEVELOPMENT ADMINISTRATION

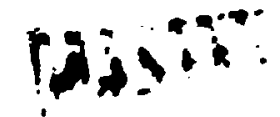


FOREAORO

ABSTRACT

1. Introdiction, SUmins, and conclusions

11 Ineroduction

1.2 Sumary

1.3 Conclusions

2. NLCLEAP PLANT RELIARILITY DATA SYSTEA.

2.1 Sumary

2.2 Evaluation - Adientages

2.3 Evaluation - Disadvantages

2.4 Avallability of Inforation

3. FAILURE DATA MURDEOK FOR NLCLEAR PONER FACILITIES . . . . . ?

3.1 - . . . . . . . . . . . . . . . . .

3.2 Evaluacion - Advancages ............... s

3.3 Evaluation - Disedvanteges . . . . . . . . . . . s

3.4 Avallabllity of Handbouk . . . . . . . . . . . . i

4. SYSTERS REIABILITY SERYIEE DATA MNK . . . . . . . . . . i"

4.1 Sumary - . . . . . . . . . . . . . . . !

¿.3 Evaluation - Disadvantages . . . . . . . . . . . !

4.t Avallability of Daca............... is

5. REACTOR SAFETY STIDY (LASH-1:00) - AppendIX III,

"FAILURE DATA"

S.1 Sumary

$\cdot \cdot \cdot \cdot \cdot \cdot \cdot$

5.3 Evaluation - Disedvantages .................. is

5.4 Avallability of WASH-1400 ............ In

6. NAVAL SHIP ENCINEERINC CENTER RELLABILITY/MUINTAIMAILITY/

AVAILABLLITY DESIG: DATA BNK REPORT

6.1 Sumary

5.2 Evaluetion - Advantages

6.3 Evaluation - Disadvantages

6.4 Avallability of Data Bank Report........... iy

7. NON-ELECTRONIC RELIABILITY NOTEBOOK . . . . . . . . . . . .

7.1 sutary . . . . . . . . . . . . . . . . 211

7.2 Evaluation - Mdvantages . . . . . . . . . . . . . . .

7.3 Evaluation - Disadvantages . . . . . . . . . . 20

7.4 Avallabillty of lotebook ............. 21

8. GOVEFMMENT/INDLSTRY DATA EXCHUNGE PROGRUM FAILI'RE RATE

DATA BANK . . . . . . . . . . . . . . . . 2

\$.1 Sumanry ...................... 22

8.2 Evaluacion - Advantages ............. 23

8.3 Evaluation - Disadvantages .............. 23

8.4 Avallability of Sumaries ..............2 21 
APPENDIX A. Liquid Metal Engineering Center (LMEC) Data ..... 25

APPENDLX B. Systems Reliability Service Data Bank (SYREL)

Data .................. 29

APPENDLX C. WASH-1400 Sumary Data ............. 33

APPENDLX D. Naval Ship Engineering Center (MAVSEC) HE

Data Bank ............... . 49

APPENDIX E. Rome Air Development Center (RALC) Data . . . . . 65

APPENDIX F. Government/Industry Data Exchange Program

(GIDEP) Enneric Codes ............. 71 


\section{FOREMORD}

This document was originally cospiled and iritten by J. R. Lennon of Bradford Computer and Systens, Inc., under Subcontract No. 3942 with Union Carbide Corpcration Nuclear Division as an activity of the RDT Standards Program. Techaical direction of the subcontract was provided by H. G. Arnold of OkWL Ergineering.

The purpose of the docusent is to provide a quick reference for reliability engineers who need failure and repair data on equipant in nuclear service. then RDT Standard F2-ST, Reliability Assurance, was prepared, the authors recognized the need for guidance in the use of t..... st :ndard to obtain data. It is hoped that this docuent will pru.ide that guidance.

As a word of caution, no clain is made that the data sources described herein are infallibly applicable to the nuclear Industry, even though the eitles ci some of the sources may imly that. The reader aust assess the meaning of the output from his calculations when using the data. 
Seven sources of reliability and intainablity data are reviewed for their potential for provtding nuclear equipent data. Consideration is given to sinlarity to nuclear application, variecy of equipent types reported, avalleillizy of deta, and obsolescence of data. Ir addition, discussions of advantages and disadvantages of each data source are presented, and saples of efther the data or the character of the data are Includec as appendixes. 
1. INTRODUCTION, SURARY, AND CONCLUSIONS

\subsection{Introduction}

Increased emphasis is being placed on the avallability/reliability/ aintainability/safety (ARHS) of nuclear reactors. In particular, the neer for design evaluation using zellability engineering techniques developed over the past two decades is evident. RDT Standard F2-9T,

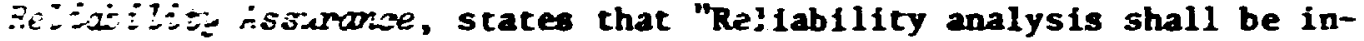
cluded as an integral part of desiga aralys13..." and Identifies certain quantitative types of arelyses including comarative analysis, sersitivity analysis, trade-off studies, and fault-tree analysis.

The techniques to perfor such analyses are in the hands of the engineering comunity today. Not so readily available are the reliability and aintainablity data required to input to such analyses. Both the Energv Research and Developent Adninistrat Ion (ERAA) and the Nuclear Regulatory Comission (ARC) are aware of th1s problea, and an effort is under way to overcone to through developmert of the Nuclear Plant Relfability Dara Systen (MPIDS). However, the collection and aualysis of data on highly reliable equipaent such as that found in a reactor and its associated systens requires sigaificant ants of reactor operating tine, hence calendar tine. Consequently, there will be a span of several years during which engineers ast rely on o:her dara sources to provide input data $2 ?$ ARYS analyses.

The ourpose of this guide is to provide an overvieu of potential sources of reliability and alntainability data that could be used for nuclear application until the tine when IPRDS, Institute of Electrical and Electronics Engineers (IEEE), and other Industry-sponsored efforts provide nuclear- and utility-generated data.

A large number of potential data sources were reviewed for possible inclusion in this guide. Dats from all branches of the Armed Services and the National Aeronautics and Spece Adeinistration vere reviewed. Inquiries were sent to the appropriate nuclear agencies in the governments of the United Kingdon, France, and Germany. ERDA installations including Oak Ridge National Laboratory, National Reactor Testing Station, and the Liquid Metal Engineering Center were requested to provide inputs. Certaln Industrial organizations belfeved to have data banks were invited to contribute.

\subsection{Sumary}

Data-source candidates were reviewed with respect to the following considerations: (1) sinflaricy of equipent to that anticipated in nuclear applications; (2) variety of equipment reported by the data source; (3) avallability of such data to the nuclear industry, both suppliers and users; and (4) data obsolescence. 
Seven daca sources veze selected as currently having the greatest potertial benefit to the nuclear industry. The seven sources are listed below along with their stition numer in this report:

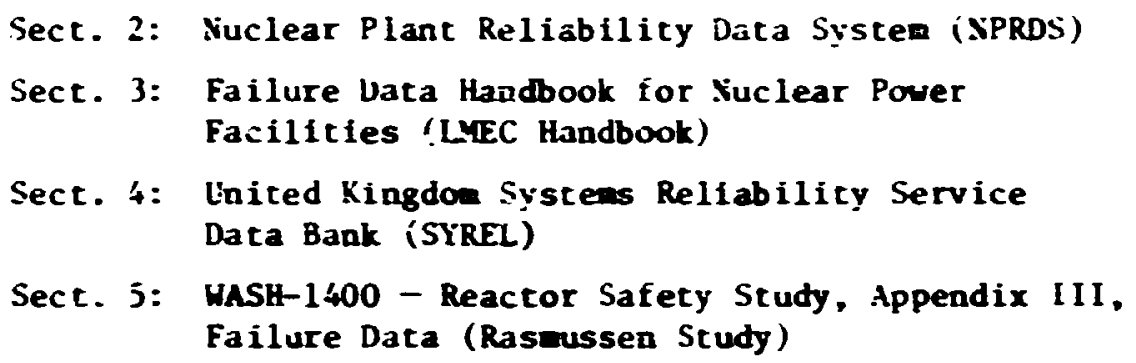

Sect. i: Rome Air Development Center (RADC) Non-Electronic Reliability diotebook

Sect. 8: Governzent/Industry Data Exchange Prograis (GIDEP) Failure Rate Data Back

(The Avco Corporation report, Reliability Engineering Data Series, "Failure Races," published in 1962 was excluded from this guide because data is based on equipment operations during the 1950s and on equipment and systems designed in the late 1940s. In addition, the report is no longer in print, although it dces serve as a good seference point to measure rellability grosith.)

Five of the seven data sources are readily available to the nuciear industry. STREL furnishes data on a subscription basis. NPRDS is avialable to participating utflities and government agencies. Although its avallability to industry is rot clear at this point; NRC is expected to release data on a need-to-krion basis.

\subsection{Conclusions}

Recent emphasis in nonelectronic reliability analysis has made available much more nonelectrcic data than was available a decade ago. These data were collected principally from nonnuclear applications but it can be used for many order-of-magnitude analyses that are likely to be undertaken for nuclear applications, especially for comparative analysis. If the objective of cuch analyses is tc lead to design improvenent rather than absolute value prediction, the errors in the data can be tolerated.

Although NPPDS should eventually prove to be the best nuclear daca source, it is recommended that those involved in nuclear system ARMS analyses obtain all the reports reviewed herein. The LMEC Handbook (Sect. 3) is the most thorough with respect to completeness of reporting on rellability data, but it does not provide maintainability data nor does il cover a large spectrum of components (84). Maintainahility data 
can be obtalned fron lisSH-1460 (Sect. S: and the iMVSEC data bank (Sect. o). The GIDEP reports contain inforation or. the largest spectrun of equipents, but the potential variabilicy of input data quality would Indicate that other reports swantized herein should be exsmined first for applicability. 


\section{NUCLEAR PLANT RELIABILITY DATA SYSTEM}

\subsection{Summary}

The Nuclear Plart Reliability Data $\leqq$ ystem (NPRDS) solfcits input information from all organizations that jperate nuclear reactors ise:primarily for generating electric porer within the linited scates. The systems and components inciuded in the NPRDS data tase are, in general, those classified as Safety Class 1 and Safety Class 2 in ANSI N18.2 and ANSI N21.1 excluding spent rue! storage, passive reactor-vessel structural intemals, pressurized water reactor piping 1 in. and below and BWR piping $1-1 / 4$ in. and below. Components are considered ro be identifiable devices, instruments, or pieces of equipment, out smali parts such as resistors or vacuur cubes are noc. The basic input information to the data bank sonsists of the following four elererts:

1. unit identification,

2. engineering data,

3. failure reports,

4. measure of exposures to faflure (e.g., service hours, cycles, or tests).

Six different output reports are provided by the NPRDS. Three of these reports are provided only to the reporting organization and three reports are available to other industry participants. This sumary is concerned only with the latter three reports.

NPRD Report A03, Annual Sumany heport of $S_{j}$ stem Reliability, provides a sumary of safety-related system reliability statistics for generic protection systems of ail similar nuclea: steam-supply systems that are reported. Reporting organizations are not identified in this su nary, but the total number of generating units and safety-related systems is indicated. Statistics are provided for the latest or current year and for the total experience recorded in the daca bank. Specific data included in this report are as follows:

- The ruclear plant operating mode that normally applies; the three possible modes are operating, standby, and shutdown;

- The period for which specific reliability statistics apply, whicn iricludes statisics accumulated for the current specified period aid statistics accumulated from the start date for the particular nuclear plant system through the end of the past calendar year;

- The total population of nuclear unit systers having the same NPKDS code on which reliability data are being reported;

- The calculated system in-service hours categorized as critical hours, reactor standby hours, and reactor shutdown hours; 
- Total in-service hours, which is the sum of the three previous categories;

- The total calculated in-service hours for tive particular system type divided by the total population of that system type;

- The summation of hours that the systems were out of service due to system or comporent railure;

- The number of failures of the corresponding nuclear plant systems for the designated period;

- The average system outage hours per fallure for the specified nuclear plant systems for the designated period;

- Number of failures per million in-service hours;

- The total number of system tests;

- The sum of all the nuclear generating units reporting;

- The summation of the reactor critfcal hnirs (current and cumuiative);

- The sumation of the standby condition hours (current and cumulative);

- The summation of the reactor shutjown hours (current and cumulative);

- The specific date of the beginning of the designated period for which the nuclear plant sys tem rellability data are accumulated and reported in the subject repurt;

- The spectfic end date of the designated period for which nuclear viant system rellability data are accumulated and reported in the subject report;

- The to al hours for which reliabflity data had been accumulated in the co:responding period.

NPRD Report A04, Sumary Report of Component Reiiability, reports similar information at the component level. The NPRDS provides a breakdown of nuclear plant componen:s by subcategories. Components may be roported as rajor subcategories or divided into as many as twa or three subcategories. Statistics for any ore component are included ir only one subcategory. The subcategories do nct overlap but are extremely useful in providing engineering and lescriptive information to identify a particular component. The report provides the total number of nuclear plant components on which statistics are based. The grand total represents the total components within the NPRD data base.

NPRU Report Q02, Quarterly Component Failure Listing, is provided on a quarterly basis to industry and contains fallure data for the same type of components included in the NPRDS file. The objective of this report 
is to provide infoimaticn on a quarterly basis that will keep industry informed of all significant component failures. Information contaitied in this report includes a description of the component, the date of failure, the sequential numbei for the reported component failure for the specified failure date (necessary in case more than oile failure occurs on a particular component on a single date), failure outage duration, description of the component failure, and cause and corrective action.

\subsection{Evaluation - Advantages}

NPRDS data reflects the environment and application factors that will be the most similar to those anticipated in future nuclear iystem designs. The report of engineering data required to be supplied by each program participant will provide the data system with accurate descriptions of components and accurate estixations of composent exposure time. The component engineering data breakdown systems and codes appear to be in sigr:ificant detail. The quarterly $Q 02$ report appears to give sufficient detail on individual part failures to assist the designer in overcoming component weaknesses.

\subsection{Evaluation - Disadvantages}

The major disadvantage to NPRDS at this time is that because the system is new, few component failures have been reported. At the current rate of componen, failures and reporting, it is expected to take from 4 to 5 years from this date for the system to collect sufficient data on enough components, particularly those with low fallure rates, for the program $: 0$ be useful for across-the-board nuclear application. The annual reports or component listings do nct provide statistics on failure modes and failure mechanisms.

The designer of nuclear systems may have to go elsewhere fcr maintainability data. Reports on faflure-outage duration or system outage are given, but stitistics on mean-time-to-repair and the reascns for the leris, th of time have beea onitted from this program.

\subsection{Avaflability of Information}

The NPRDS is under the auspices of Edison Electric Institute (90 Park Avenue, New York, New York 10016). The program itself is handled under contract by Southwest Research Institute, San Antonio, Texas, under the direction of the ANSI Subcomit tee N18-20. Southwest Research has prepared a Reporting Procedures Ma iual for the NPRDS which includes input format, output furmat, and necessary codes and categories in order to interpret the resulting reports. There is some indication that nonparticipants may, in the futur?, be al! owed to receive reporta on a subscription basis; however, information relating to specifics is not available at this time. 


\section{FAILURE DATA HANDBOOK FOR NUCLEAR POWER FACILITIES}

\subsection{Sumari}

The Liquid Metal Engineering Center (IMEC) published the Failure Data Handbock for Nuclear Power Faci'ities in August 1969 and released a revised edition in June 1970. The handbook is subtitled A luide for the Design, Construction and Maintenance of Huclear Power Plants from a Reliability Improvement Stcondpoint.

Data included in the handbook were taken from operating experience on the Experimental Breeder Reactor II (EBR-II) at the National Reactor Testing Station, the Sodium Components Test Installation at LMEC, the Large Components Test Loop ai: LMFC, the Sodium Reactor Experiment, the Hallam Nuclear Power Facility in Nebraska, and the Enrico Fermi I Atomic Power Plant in Mirhigan. The latter three facilities contriubted dat: only on sodium and related system component failure events. The handiook was developed in supjort of the Liquid-Metal Fast Breeder Reactor (LMF.3R) Prcgram, but the disa should be of significant value on other nuclear projects.

Failure data were obtained from a variety of sources including ( 1 ) facility publications (1.e., progress reports, fallure reports, incident reports, etc.), (2) maintenance work orders, (3) component history records (4) verbal communications, and (5) other miscellaneous documents.

During the period covered by the data, 1188 malfunctions were recorded over a population of 84 components and subcomponents. The 84 components, for which at least one malfunction was recorded, are given in Table A.1 (Appendix A). Of the 84 components that experienced fatlures, $30 \%$ of the components experienced three failures or less while $25 \%$ experienced 16 or more fallures.

Each of the 1188 fallures is itemized in the handbook with the following information: component/part, system/subsystem, facility, component location, operating conditions, source document, fallure cause, fallure mole, fallure effect, operating hours, method of fallure detection, failure description, corrective action, and recommendations.

A sumary of fallures ("Pailure Distribution Functions") for each conponent type (e.8., valves, such as condensate valve and feedwater valve) is presented. Percentage of fallures by (1) plant type, (2) system, (3) component part, (4) cause, (5) mode, and (6) ef fect is given for each component type. Percent of fallures, by cause, mode, and ef fect is also given for the component class (e.g., valves). Total fallures, operating hours, and fallure rates are also taiulated by each component/subcomponent type.

A narrative precedes each component data section and summary. This narrative discusses design features, critical characteristics, modes of fallure, fallure description, control methods, and recommendations. 
When nectssary, a diagram of the component and its constituent parts is provided.

The handbook also contains a section entitled "System-Oriented Component Failures." One hundred two of the 1188 failures were placed in this category because the cause of failure was more properly described as a source external to the component. Forty six of these were designated as failures due to existing system actior. Corrective action for the se types of failure would necessitate design changes or modification to systems or components. The remaining 56 failures were caused by (1) improper design of a component which results in the failure of a related component; (2) use of inadequate operating or maintenance procelures; or (3) l.ack of the r.eressary protective device or system to assure proper component or system operation. Each type of failure is summarized together with operating hours, number of fallures, failure description, corrective action, and recommendations.

Section III of the handbook summarizes sodium leak information which identifies the falled component, the line size associated with the component, the leakage incident, the amount of sodium lost during the leak, the hours of component cperation prior to failure, the means by which the leak was detected, and the sources from which the information was gathered. Eighty sodium leaks are covered in this section.

The handbook also contains tutorial sections covering reliability/availability analysis and maintainability. Of particular interest is an extensive and complete bibliography on reliability, maintainability, system effectiveness, statistics, testing, and specifications and standards in relfability, quality assurance, maintainability, safety, human factors, and value engineering.

\subsection{Evaluation - Advantages}

The in-depth coverage given in this handbook, particularly in areas of failure cause, mode, and effect, is far more comprehensive than any other summary currently available. The user is provided information related to method of falluie detection, failure description, corrective action, and recommendations. The recomendations will be particularly helpful in future LMFBR designs. The bibliography is one of the most extensive available, particularly in the area of standards and specifications.

\subsection{Evaluation - Disadvantages}

The major deficiency of this handbook is the small nimber: of failures from which conclusions must be drawn. With only 1188 fail'ires reported on 84 components, the confidence in fallure races relating to several specific components is low. Table A.1 lists the number of failures reported for each component. 
Insufficient data were available on operat 8 hours for 13 ciasses of subcomponents; therefore, valid calculations of failure rates or meall time between failures are not possible. Mean time between failures for the remaining 71 components/subcomponents have been calculated and, together with the 90\% confidence incerals, are listed in Table A.1.

Althcugh the handbook contains tutorial information on maintainability, no quantitative dáta are available.

\subsection{Availability of Hindbook}

The handbook is distributed by the National Technical Information Service (NTIS), U.S. Department of Commerce (5285 Port Royal Road, Springfield, Virgisia 22151). The full title is

Eailure Data Eandbook :On lucleur Dwer Facilities

A Suide for the Design, Construction, and Maintenance

of Nuclear Power Plants from a Reliability Improverent Standpoint

Vol. 1: "Failure Data and Applications Technology"

Issued Augus: 15, 1969, rcvised June 30, 197n

Vol. 2: "Failure Category Identification and Glossary" June 20, 1969

LMED - Hemo - 67-?

Contract AT $(04-3)-700$

Liquid Metal Engineering Center, operated for the ISAEC by Atomic International, A Division of North Americán Rockuell Corporation

In requesting the two volimes from NIIS, refer to UIEC - Memo - 67-7.

The hasdbook also contains tutorial sections covering reliability/ajallabilicy analysis and maintainability. Or particular interest is an extensive and complete bibliography on reliability, maintainability, system effectiveness, statistics, testing, and specifications and standards in relfability, quality assurance, mantainability, safety, human factors, and value engineering. 


\section{SYSTEMS REL IABILITY SERVICE DATA BANK}

\subsection{Sumary}

The Systems Reliability Service Data Bank (SYREL) is the comprehensive rellability data bank that forms an integral part of the lnited Kingdom Atomic Energy Authority (UKAFA) Systems Reliability Service. By October 1973 the SYREL Reliability Data Store coniained in excess of 3500 reliability data entries on some 900 plant items collected from a wide range of industrial and nuclear plant uperating experience and from test procedures carried out by manufacturers and research organizations.

The data bank serves two main pirposes: It provides information to its contributors on the performance, availabilicy, and reliability cf their own plants; and it provides the generic reliability data required by the design and reliability engineers of associate members of the Systems Reliability Service (SRS). The data bank does not publish periodic sumary reports as do other banks sumarized herein; however, it does provide data in specia!. reports available to associate members for a fee. The types of data stored in the bank are best described by Fig. 4.1. These data may then be recalled, analyzed, and sorted in a variety of combinations at the request of an associate member. Table 4.1 lists some of the headings under which it is possible to retrieve data. Table B.1 (Appendix B) shows a selection of typical items of reliability data which have been supplied in response to requests from associate nembers. The categories of component types which may be found currently in the data bank are identified in Table B.2. The number in the parentheses following each category indicates the number of subcategories under each category for which there is data.

There are several ways to obtain generic reliability data from SY.EL.

1. An ass;ociate member of SRS who is contributing data to SYREL from his plant or who can offer a suitable exchange service is normaliy entitled to receive generic reliability data at no cost.

2. In the absence of some suitable axchange agreement, associace members may purchase generic reliability data from SYREL at a nominal charge. The actual charge made will depend on the nature of the information required. In general, the direct purchase of data is not encouraged because it departs from the principle of mutuality which is fostered in the club atmosphere of the SRS.

3. All the data used by SRS in the course of a relfability assessment cairied out under contract are made available to the customer as a par: of the assessrent report. 


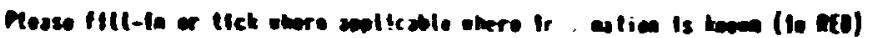

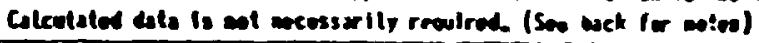

\begin{tabular}{|c|c|}
\hline find $\operatorname{mex}($ Lee eolo 1$)$ & \\
\hline \multicolumn{2}{|l|}{ micina } \\
\hline \multicolumn{2}{|l|}{ 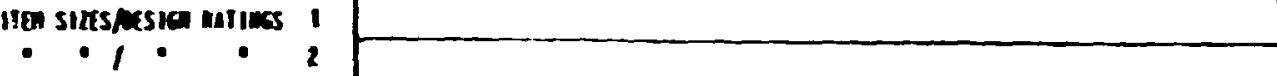 } \\
\hline \multirow{2}{*}{\multicolumn{2}{|c|}{ 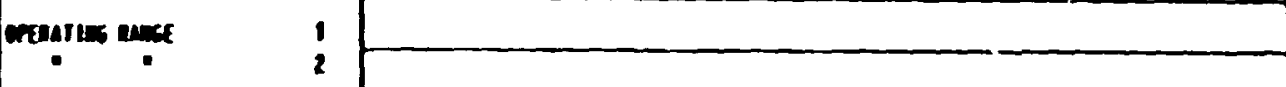 }} \\
\hline & \\
\hline 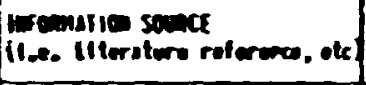 & Ta \\
\hline \multicolumn{2}{|l|}{ Iren resainie } \\
\hline \multicolumn{2}{|l|}{ 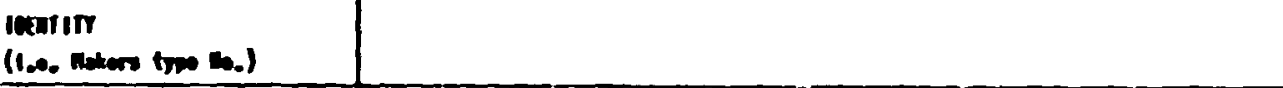 } \\
\hline \multicolumn{2}{|l|}{ muin of irens } \\
\hline 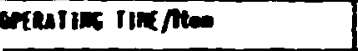 & 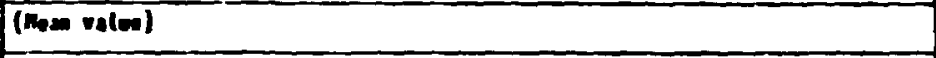 \\
\hline \multicolumn{2}{|l|}{ Esicuen (nsos of flon) } \\
\hline \multicolumn{2}{|l|}{ Emive of finis } \\
\hline Q. of crars a onainosite & Gem value \\
\hline Esube (Eloctronte elraits) & 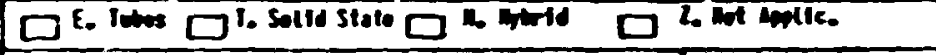 \\
\hline fand cercont & 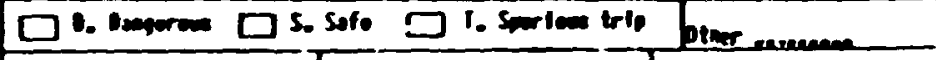 \\
\hline \multirow[t]{3}{*}{ 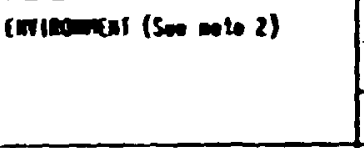 } & reminutene \\
\hline & vianion \\
\hline & comins ion \\
\hline mmicalion & 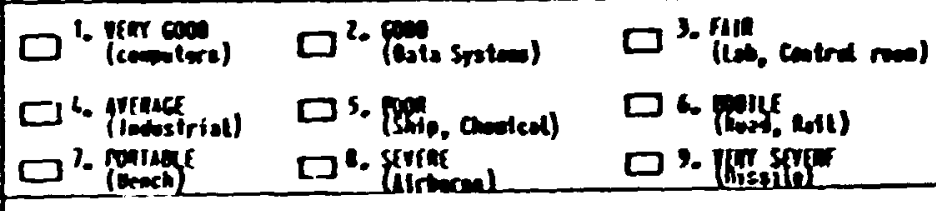 \\
\hline mre or insonsisen & 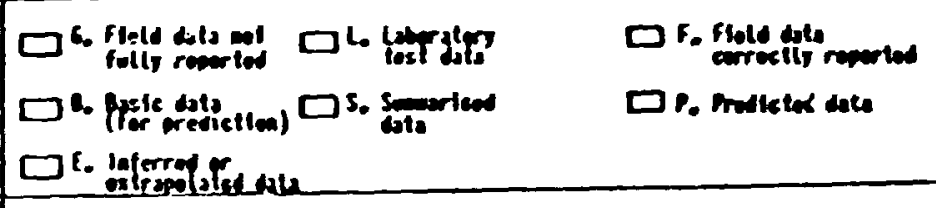 \\
\hline \multicolumn{2}{|l|}{ 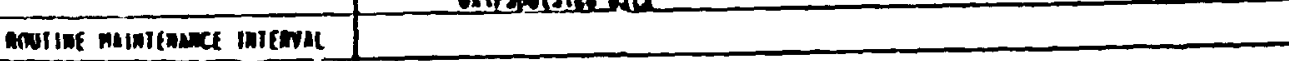 } \\
\hline \multicolumn{2}{|l|}{ 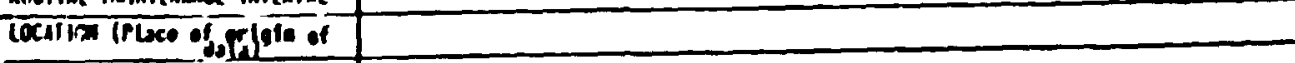 } \\
\hline \multicolumn{2}{|l|}{ ESich Tem } \\
\hline mentitr & 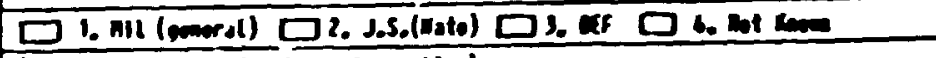 \\
\hline uisiont Iing/lice & (Iive wor stleh callexted dats anlles) \\
\hline \multicolumn{2}{|c|}{ D. o irems I ine on ctars } \\
\hline Falluar ante & Enem \\
\hline \multicolumn{2}{|l|}{ coasriosmer and } \\
\hline \multirow{2}{*}{$\frac{\text { Jink, cic. ron essis of calc. }}{\text { oisiniouiton }}$} & 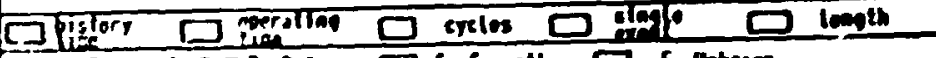 \\
\hline & 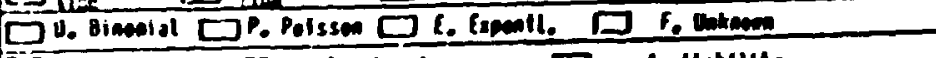 \\
\hline 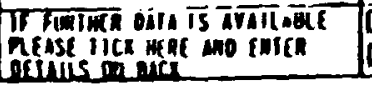 & 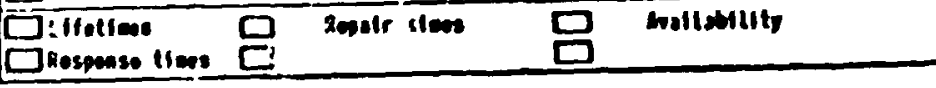 \\
\hline
\end{tabular}

sioned

Fig. 4.1. Information for rellability data bank. Source: Systems Reliability Service, United Kingdom Atomic Energy Aurhority. 
Table 4.1. Performance and rellability information obtainable from SYREL

Equidoment

1. Mean time between failures

2. Mean time to repair (breakdown)

3. Minfmum and raximum repair (breakdown times)

4. Mean time tetween maintenance

5. Mean time to maintain

6. Minimum and maximum maintenance times

7. Mean man-hours pez maintenance

8. Minimum and maximum man-hours per maintenance

9. $z$ reliability (relative to $t=$ mean $t$ ime between maintenance)

10. 2 availability $=\left(\frac{\text { operating }+ \text { available for operation cimes }}{\text { total time }}\right)$

11. Number of modifications

12. Mean man-hours (breakdown + maintenance) cost

13. Yean materials/parts cost

14. Operating cost (sun of 12 items and 13)

\subsection{Evaluatior. - Advantages}

The SRS data bank was established to generate and disseminat? reliabiility information for industry, government, and others who require a knowledge of or have an interest in rellability ard avaflability statigtics. As Fig. 4.2 shows, the data included in the bank are quit? couprehensive. The number of components for which at least one data element is avallable is also quite large.

\section{Evaluation - Disadvantages}

The major disadvantage of the SYREL data bank for users in the Uniteu States is its relatively lower availability to most designers. The United States is represented by both NRC and the Reactor Division of Oat Ridge National Laboratory. nẹher organizations interested in obtaining this data should apply for assuciate wembership with SRS. Another potential disadvantage is the predonination of foreign data that may ref lect diffurent environnents or the impact of different regulations and policies. SYREL does not publish general sumary reports; all reports result from special requests. 


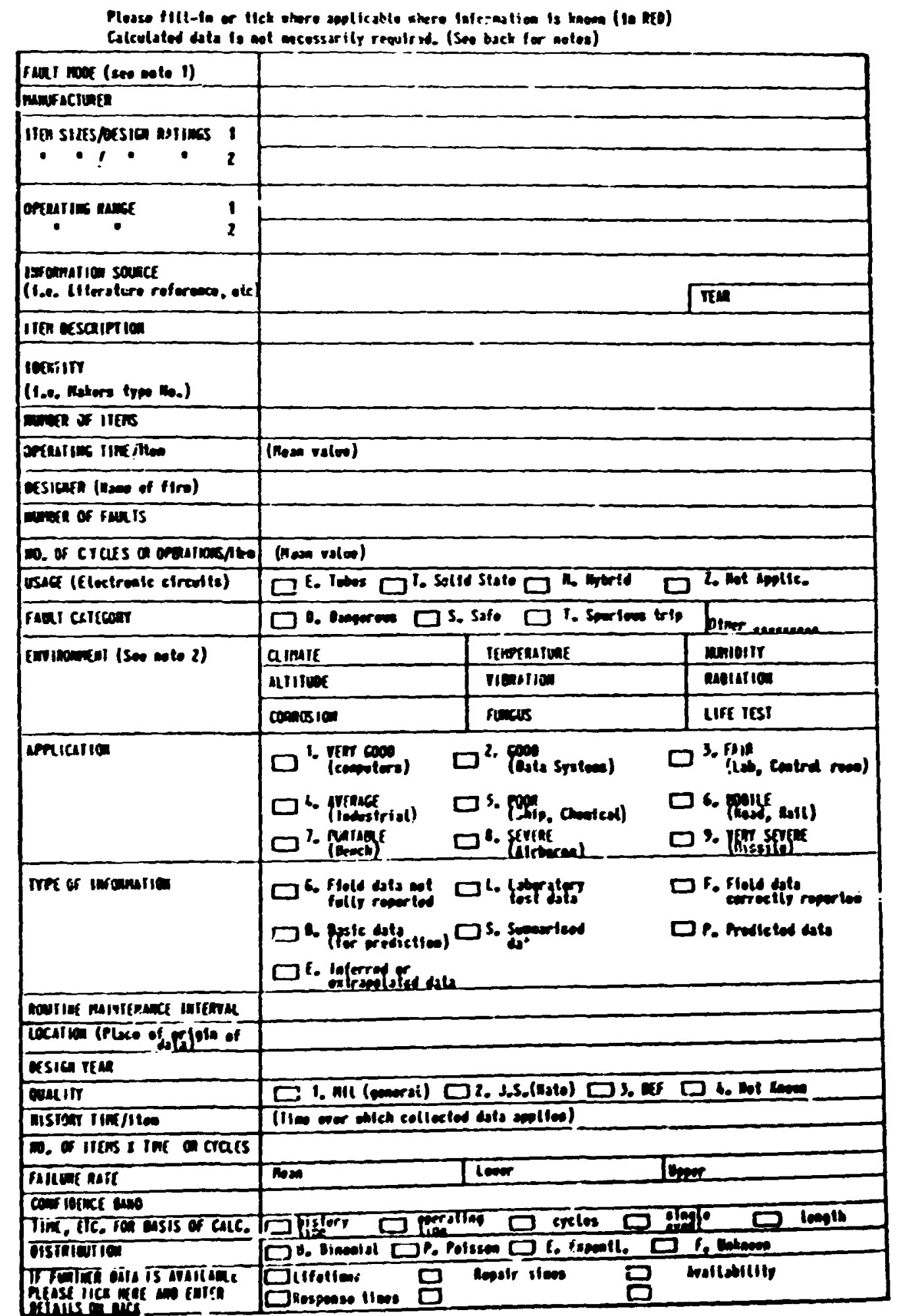

Fig. 4.1. Informatio: for reliablitty data bank. Source: Systems Reliablity Service, United Kingdom Atomic Energy Authority. 
Table 4.1. Performance and reliability information obtainable from SYREL

Equipment

1. Mean time between failures

2. Mean time to repair (breakdown)

3. Minimum and maximum repair (breakdown times)

4. Mean time between maintenance

5. Mean time to maintain

6. Minimum and maximun maintenance times

7. Mean man-iours fer maintenance

8. Minimum and maximum man-hours per maintenance

9. Z reliability (relative to $t=$ mean time between maintenance)

10. $\%$ availability $=\left(\frac{\text { operating }+ \text { available for operation times }}{\text { tosal time }}\right)$

11. Number of modifications

12. Mean man-hours (breakdown + maintenance) cost

13. Mean materials/parts cost

14. Operating cost (sum of 12 items and 13)

\subsection{Evaluation - Advantages}

The SRS data bank was established to generate and disseminate reliability Information for industry, government, and others who require a knowledge of or have an interest in reliability and avallability statistics. As Fig. 4.2 shows, the date included in the bank are quite comprehensive. The number of components for which at least one data element is avallable is also quite large.

\subsection{Evaluation - Disadvantages}

The major disadvantage of the SYREL data bank for users in the United States is its relatively lower avallability to most designers. The United States is represonted by both NRC and the Reactor Division of Oak Ridge National Laboratory. Otiner organizations interested in obtaining this data should apply for assoctat embership with SRS. Another potential disadvantage is the predomination of foreign data that may ref lect different environments or the impact of different regulations and policies. SYREL does not publish general sumary reports; all reports result from speclal requests. 


\subsection{Avallability of Data}

Information relating to membership should be directed to

Systems Rellability Servize

UKAEA

Wigshaw Laze

Culcheth, Warrington, Lancashire, WA34NE

United Kingdom

ORNL-DWG 76-17251

SYSTEMS RELIABILITY SERVICE - DATA BANK

EVENT

\begin{tabular}{|l|}
\hline $\begin{array}{l}\text { STAGE } 1 \\
\text { Inveniory dete }\end{array}$ \\
\hline \\
Plant manuels \\
Drowings \\
Specificetions \\
Doto sherrs \\
otc
\end{tabular}

Inventory no

Manulacturer

Designer

Design veser

Commissioning dote

Seriel no

Identity

Populetion

Renge/size

Quelity

Concuit eype

Apolication

Emuronmant al

Meterial

Mointenence type

Meintenence intervel

IIem code

Time function

Creles/reer

Medie

Installation

Full deseriotion

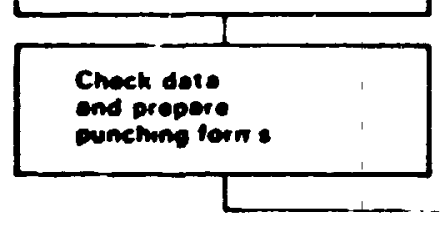

DATA

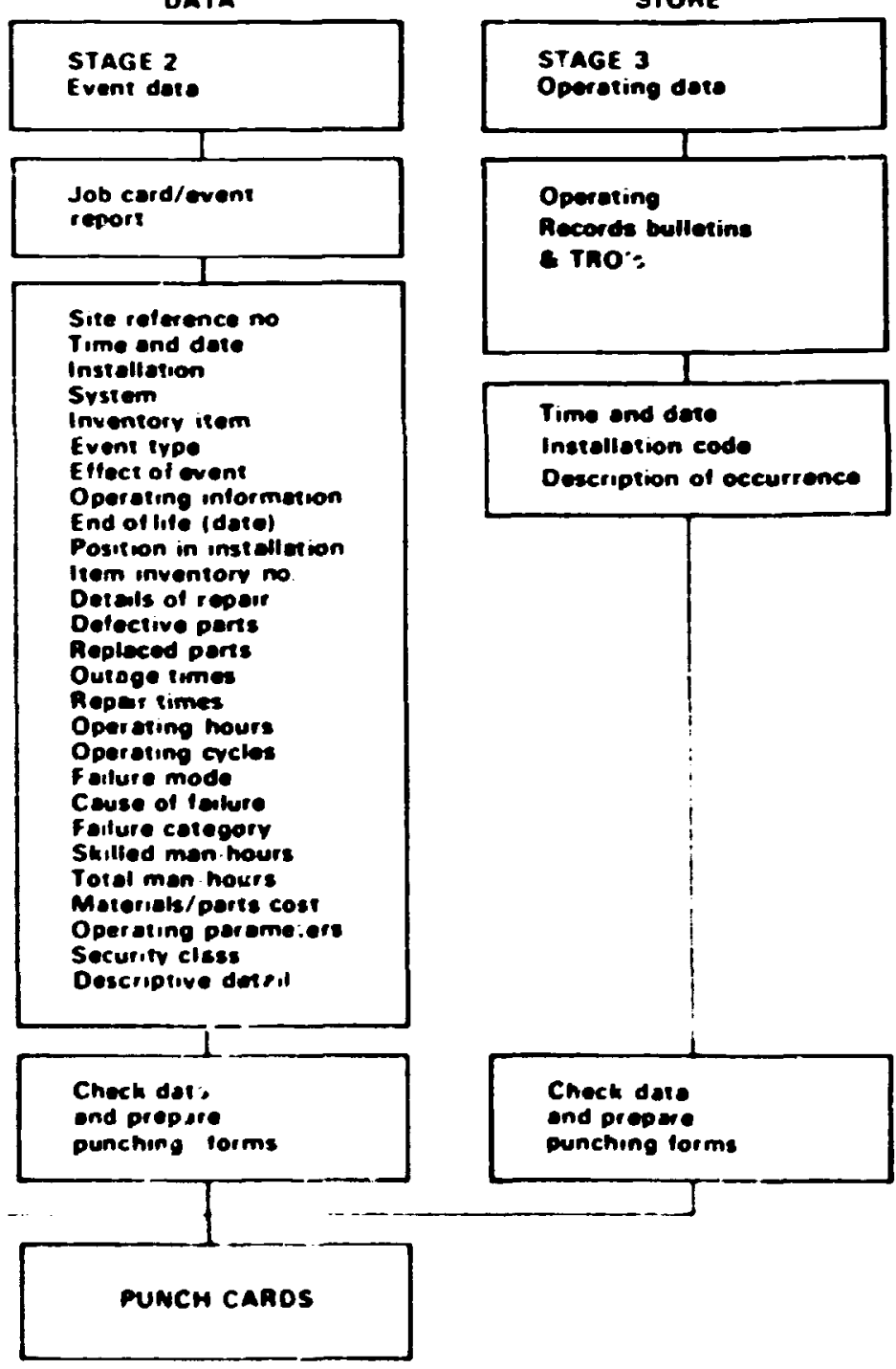

Fig. 4.2. Three stages of data collection und preparation in the SRS data bank. Source: Systems Reliability jervice, United Kingdom Atomic Energy Authority. 
5. REACTOR SAFETY STUDY (WASH-1400) - APPENDIX II', "FAILLRE DatA"

\subsection{Sunmary}

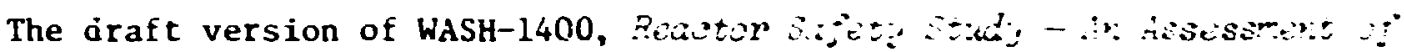

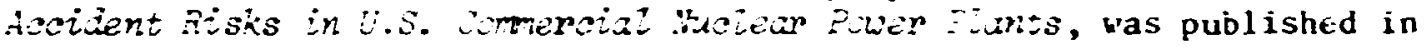
August 1974 by the U.S. Atomic Energy Comission. Appendix III, "Failure Data," describes the methodology used to ol: in the failu:e rates and repair times necessary as inputs to system models developed for the WASH-1400 study (Rasmussen Study). The failure rates used in the study we-e derived from reference handbooks, reports, operating experience, and nuclear power plant experience.

Because the goal of WASH-1400 was risk analysis, as opposed to reliability analysis, the authors chose not to use point estimates as has been done in most other data summaries and analyses. Instead, a range of values was determined so that the tzue value would have a high probability of falling within the range. One of the reasons the range approach was chosen was because of the inadequacy of available pertinent data. The authors aiso contend that this approach incorporates uncertainties and variations due to the use of difterent reporting sources, variations in application, fluctuations in the daily operation and environmental conditions, and variations that can exist from one component to another. The authors also point out that the range approach is flexible and general, yielding narrow ranges where there is more accurate knowledge or little variation and yielding wider ranges where there is less resolution or less sonstancy of behavior. The final assessments are one or two orders of pagnitude in width consistent with the resolution of the source data. The source data used in the range assessment were diverse and represented a spectrum of conditions and applications. Included as tata sources were SYREI and GIDEP, which are described in other sections of this report.

Tables C.1, C.2, and C.3 (Appenjix C) have been extracted from WASH-1400, Appendix III, in order to summarize the data found therein. Table C.I is a summary of assessments for mechanical equipment while Table C. 2 is concerned with electrical equipment. The tables contain the assessed ranges for the data, the median value of the range, and the error factor as coupared with current nuclear experience. The range represents a $90 \%$ likel thood, or conildence level, associated with the log normal. The median is a reference value for the range, there is a 50-50 chance that the true value is either higher or lower than the median value. The error factor is the limit of the range divided by the median value. Nuclear data statistics were derived from 1972 commercial reactor exper ence. Units for the data are probability per demand, $d$, or per hour.

Failure mode frequency is expressed as fallure rates or demand probabilltics. Operating failure rates. $\lambda$, are provided for those components whirin are required to operate or function for a perlod of time. Standby fallure rates, $\lambda$, are provided for those passive-type devices, such as pipes and wires, that are normally dormant or in standby until they are 
tested or an accident occurs. Finally, for those components that are required to start, change state, or function at the time of the accident, the probability that the device will fail to operate upon af:and is given. These demand probabilities, denoted by $Q_{d}$, incorporate contriburions from failure at demand, failure before demanc. as well as failure to continue operation for a sufficient period of ti.je fo successful response to the need.

Except for pumps, the applicable environment consists of standard operational power plant conditions. The ranges cover variations that can occur in these environments. Pump data (failure to run, given successfui start) was assessed in light of extrere temperature and pressure conditions characterizing a severe accident.

Tabje $\mathcal{C} .3$ compares the assessed ranges with the raw input values extracted from various sources. These sources are further identified $i_{i 1}$ Appendix III of WASH-1400.

Appendix III of WASH-1400 aljo includes notes on various considerations usec in deriving data shown in the aforementioned tabies, test time, human reliability analysis, aircraft crash probabilities, failure data, total loss of electric power, one-line sumarles of the failures relating to 1972 operating Inctdents, nuclear plant reliability experience during 1972 which included approximately 700 failures and anomalies, and a discussion on common mode failures.

\section{S.2 Evaluation - Advantages}

This is a recent data evaluation and the only one that attempts to present data specifically for bofling water reactor and pressurized water reactor environments. It recognizes the importance of fallure mode data, standby failure rates, and demand probabilities. The oneline summaries of the 1972 operating incidents are of interest. The analysis of test and naintenance time of nuclear components is also unique to this report. It is the only source that provides a point estimate (computational median) and a range assessment.

\subsection{Evaluation - Disadvantages}

WASH-1400 provides data ranges for less than 30 component types. These ranges are predictions for a general generic type and do not differentiate between various devices that may fall within the generic type. This is recognized by the authors themselvos who stated "this data may not be sufficiently detailed, general, or accurate enough for use in other quantitative reliability models or in applications irvolving greater specificity." Con.oonent descriptions are, for the most part, too general to use their ccrresponding fallure rates for re? fability analyses of more detafl than risk assessment. 
The data sürces from which HeSH-1400 extracted ifformation should be considered. For example, the AVCo report was published in 1962 and was based on data observed in the mid 1950s and on design emanating from the 1940 s. Some Europcan sourses appear to have used identical data sources. Any conclusioti based on the distribution within a given range assessment courd, therefore, be in error. The basic report states that, based on the assessment by specialists, "component failure rates and cheir uncertainties were increased as deemed warranted." Finally, the ferivation of standby failure rates and demand probabilities tased on source data is not explained.

\subsection{Availability of WASH-1400}

WA:H-1400-( Draft) is distributed in both microfiche and hard copy by National Technical Information Service (NTIS), U.S. Department of Comwerce (5285 Port Royal Road, Springfield, Virginia 22151). The full title is

Reactor Safety Study

Ar. Assessment of Accident Risks in U.S. Commerciai iuclear Power Plants

United States Nuclear Regulatory Commission October 1975

The Reactor Safety Study report has ten appendixes. Appendix III, "Tailure Data," can stand alone as a data source. 


\section{NAVAL SHIP ENGINEIRING CENTER \\ RELIABILITY/MAINTAINABILI:Y/AVAILABILITY DESIGN DATA BANK REPORT}

\subsection{Summary}

The Naval Ship Engineering Center Reliability/Maintainability/Availability (NAVSEC RMA) Design Data Bank Report provides a summary listing of two major categories of equipment: hull, mechanical ind electrizal (HME), ano electronic naval shipboard equipment. A data listing entitled "RMA Summary rrintout" is a standard product of the data bank and is produced automatically whenever the design data bank report is updated. Data relating to electronic equipwent pertains to very few components of interest to the $n$. :lear community; the discussion therefore refers primarily to the HRE data.

The RMA Summary Printout for HME equipment contains over 600 entries. The data is derived predominant ly from observed shipboard operations. These inputs are usually extracted from analysis reputs performed either by the Navy or one of its contractors. Sources are identified. The majority of the data is from the 196? to 1969 operational lime period. Data are presented at the equipment level. liata at the compenent level, for example, seals, valves, relays, and circuit breakers, are not currently available. Table 6.1 gives an indication of the types of equipment, both HME and electronic, that are included in the design data bank report. Each of the more than 600 HME listings is unique either because of equipment nomenclatures, characteristics (e.g., horsepower), application, or sot ree.

The RNA Summary Printout includes the following data elements:

1. equipment name and general description,

2. type of ship upon which the data were observed,

3. calendar time over which the data were collected,

4. number of failures used to generate the figure of merit,

5. mean time between failure reported and listed by the following priority: observed, measureci, predirted, and specifjed.

6. number of corrective actions including failures that were reported,

7. mean time to repair (arithmetic) reported by the activity and listed by the following priority: observed, measured, predicted, and specified,

8. data source.

Appendix D is a reproduction of the HME Section of the 1975 revision of the "RMA Summary Printout" of the NAVSEC Design Data Bank Report. 
Table 6.1. Component identification number locator

\begin{tabular}{|c|c|c|c|}
\hline OC & ORLNANCE & 5; & CaPSTANS \\
\hline 1 & P'JMi'S & 54 & PRINTING EQUIPMENT \\
\hline 2 & BOIL.ERS & s5 & REELS \& TOWING EQUI PMEHT \\
\hline 3 & HEAT EXCHLNGERS & 56 & DAVITS \\
\hline 4 & COHIIENSH:RS & 57 & CRANES \\
\hline 5 & TURBIHES & 58 & HOISTS AMTUNITION HANDLING EQUIP. \\
\hline 6 & COIPRESSORS & 59 & EI.EVATORS \\
\hline 7 & HEATERS & 60 & STEERING GFARS \\
\hline 8 & DISTILLING PI ANTS & 61 & CONTKOL EQLIP-CONSTANT FREQJENCY \\
\hline 9 & BATTERY CILARCERS & & CONTROLS - AKFLIDYNE \\
\hline 10 & HETERS & & CONTROLSS - ELE.CTRICAL \\
\hline 11 & CONUEITTERS & & CONTROI.S - MECILNICAL \\
\hline 12 & MAINTEMANCE \& REPAIR SHOP EQUIPMENT & & CONTROLS - ROTOTROL \\
\hline 13 & TRANSFOR:IERS & & CONTROLS - SELF SYNCHRONOUS \\
\hline 14 & CIRCUIT BRFAKERS & 62 & UINCHE.S \\
\hline 15 & CONTROLLERS & 63 & WINLLASSES \\
\hline 16 & GENERITORS & 64 & FIRE FIGHTING EQUIPMENT \\
\hline 17 & MOTORS & 65 & LUHRICATORS \\
\hline 18 & MOTOR CENERATORS & 66 & ENGINES \\
\hline 13 & RELAYS & 67 & PLUMEING EQUIIPAENT \\
\hline 20 & RHEOSTATS & 68 & MAG.VETOS \\
\hline 21 & SHITCHES & 69 & GEARS \\
\hline 22 & SHITCHBOARDJ & 70 & COVERNORS \\
\hline 23 & AIARMS \& SIGNALING DFVICES-VISUAL & 71 & IGNITION EQUIPAENT \\
\hline 24 & $\begin{array}{l}\text { LICHTING FIXTJRES \& LAMP (ELECT-NON } \\
\text { ELECT) }\end{array}$ & $\begin{array}{l}72 \\
73\end{array}$ & $\begin{array}{l}\text { MINOR LANDING CRAFT \& SMALL BOATS } \\
\text { EJECTORS }\end{array}$ \\
\hline 25 & GYRO CORTASS EQUIPAENT & 74 & EDL:C:TORS \\
\hline 26 & PROJECTIOA EQUUIPME: in & 75 & STRAINERS \\
\hline 27 & INTERIOR COSALAICATION EQUIPMENT & 76 & PURIFIERS \\
\hline 28 & $\begin{array}{l}\text { NAVIGATIONAL EQUIPMENT (alsJ TIME- } \\
\text { PIECES) }\end{array}$ & $\begin{array}{l}77 \\
78\end{array}$ & $\begin{array}{l}\text { TRAPS } \\
\text { CCUPLINGS }\end{array}$ \\
\hline 29 & INJECTCRS & 79 & SILENCING EQUIPMENT \\
\hline 30 & BLRNERS & 80 & BRAKES \\
\hline 31 & MARINE HARDWAR: S HULL ITEMS & 81 & BLONEFS \\
\hline 32 & REFRIGEIUTION EQLIPMENT & 82 & WELDING SYSTEMS \\
\hline 33 & AIR CONDITIO:HINC EQUUIYAENT & 83 & SIIP \& SUAT RROPULSIUN COMPOAENIS \\
\hline 34 & STARTERS & 84 & SICK-BAY FQUIFATNT \\
\hline 35 & KTPERS & 85 & DI.CK MACHINERY \\
\hline 36 & ALARY; \& SICNA.T:C DEVICES-NUDIBLE & 86 & PIOTOGRAPHIC EQUIPIANT \\
\hline 37 & BEARINCS & 87 & UNDERLATER LOG EQUIPMENT \\
\hline 38 & INDTCATORS & 88 & VALVES \\
\hline 39 & CLUTCHES & 89 & FIRE FIGIITING RESCLE \& SAFETY EQUIi'. \\
\hline 40 & FANS & 90 & RIGGING \& RIGGING, GEAR ( BOOMS, ETC.) \\
\hline 41 & SHOS EIRLITHE.ST & 91 & INI"DORY EQUIPMENT \\
\hline 42 & RECUIATORS & 92 & TNNHS \\
\hline 43 & CAILEY FuYUIMYSTT & 93 & PIP:, TI!BING, HOSE \& FIITINCS (METAI. \& \\
\hline 44 & DF.W:ALDIFIC.ATION EQIIIMTAT & & FI.EXI GLL.) \\
\hline 45 & CACES & $9 / 1$ & ASh \& MINHSWI:TPING l:RUT'SIIHT \\
\hline 46 & 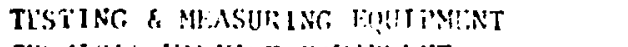 & 95 & 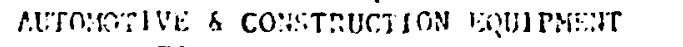 \\
\hline 47 & 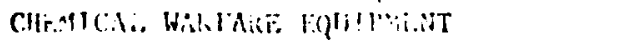 & 96 & 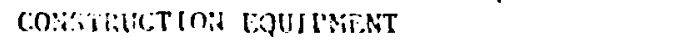 \\
\hline 43 & FII,T Liw: & 97 & MRASCON!S \& MAST \\
\hline 44 & CARHURT:IOR: & 38 & 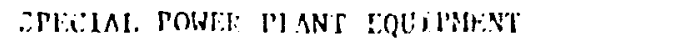 \\
\hline 50 & PANELS & 99 & 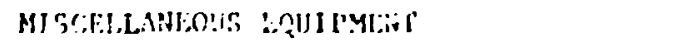 \\
\hline 31 & ISOH.ATHKä & & \\
\hline 52 & 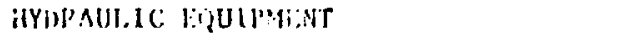 & & \\
\hline
\end{tabular}




\title{
6.2 Evaluation - Advantages
}

The NAVSEC data bank (HME portions) provides data heretofore unavailable on heavy machinery. The data can be traced to specific applications ard provides both mean-time-to-faiiure and mean-time-between-corrective actions. Relatively narrow confidence bands can be established due to the large number of observations for most entries. The NAVSEC jata bank provides maintainability information that relates to total active repair time.

\subsection{Evaluation - Dis sacivantages}

Although this data bank is one of the few sources of machinery reliability and maintainability data, the data is not from a nuclear environment or even a utility environment. The data bank does not include failure mode information. The current version of the data bank concenirates primarily on the data observed from 1967 to 1969 and, therefore, may not relate to the state-of-the-art.

\subsection{Availability of Data Bank Report}

The NAVSEC Design Data Bank Report and other special printouts may be obtained by non-Navy branches of the government dnd their respective contractors by writing to

\author{
Commander \\ Naval Ship Engineering Center \\ Hyattsvi11e, Maryland 20782 \\ Attertion: Code 6112
}




\section{NON-ELECTRGNIC REILABILITY NOTEBOOK}

\subsection{Summary}

The USAF Rome dir Developarst Center ( area of nonelectronic rellability data for the past decade. These efforts culminated in the RADC Non-Electronic Rellability Notebook. The latest revision of the data section (Sect. 2, "Part Failure Data"! was released in lanuary 1975. It was prepared under contract by the orlando Division of Martin Marietta Aerospace Corporation. Failure rate data are given for approximately 300 types of components and parts. Table E.1 (Appendix E) identifies these devices.

The data presented were taken from military operating and test experience ir. a variety of dormant, ground, subwarine, shipboard, airborne, helicopter, missile, and satellite applications. Some failure rates were derived through the synthesis of stmilar generic part types. Other data were extracted from other data collection programs such as GIDEP.

Fallure rate data for each part type axe arranged by enviromental application and are interpreted in fallures per million hours or per million part cycles. If the data upon which the failurs rate is based contain one or more failures, values for the two-sided $90 \pi$ confidence limits associated with the point estimates are also given. Failure rates based on data where zero fallures vere experienced were derived using the upper $60 \%$ confidence level and are so indicated.

A list of envirunmental $K$ factors is given with each component failure data summary sheet. These $K$ factors are intended to indicate the difforence caused by the environmental stress on a given part type.

\subsection{Evaluation - Advantages}

The RADC Non-Electronic Reliability Notebook covers over 300 component part types in a variety of environments. It is the oxly publication of its kind with a coverage this broad and with reporting depth that resulis in a narrow confidence interval at $90 \%$ confidence. It is one of the few sources that provides environmental factors. The inclusion. fallure rates for items without recorded failures is a unique feature as is the insight with respect to the impact of the environment.

\subsection{E aluation - Disadvantages}

The major disadvantage of this data source is that no data from the nuclear industry are included. Specific data sources, inr example, type of system, are not given. The notebook does not provide failure cause, mode, or effect data, nor does it provide maintainability data. Finally, no design recommendations or corrective action data are availab?e. 


\subsection{Avallabliticy of rotebook}

The notebook is distributed by the Sational Technical Inforeation Serifice (MTIS). U.S. Departwent of Comerce (S28S Port Royal Road, Springfield, Virginia 22151). The full citle is

RADC Non-Electronic Rellability Notebuok

RADC - Tr - 69 - 458

D. F. Coecrell, T. K. Gagnier, E. H. Kinball, T. W. Kirejczyk, et al.

Marcio Marletta Aerospace

In requestiag the notebook fron MTIS, refer to ITIS AAOC2899. 


\section{GOVERUTENT/INDUSTRY DATA EXCHANGE PRGGRAM FAILURE RATE DATA BANK}

\subsection{Sumary}

The Government/Industry Data Exchange Program (GILEP) Failure Rate Data Bank consists of two major seclions: a computer data storage and retrieval system and a backup microfilm bank file.

The computer data storage and retrieval system is used for the standard fallure rate and replacement rate data listings, special calculations, and searches. This data bank systea has been estab! (shed to facilitate rewote terninal access compatible with the GIDEP remote terminal programs.

The acrofilm data bank file is used for storage and distribution of source documents, fallure analysis curves, methods used in the collection of the data, additional information too extensive to include in the computer lata back, and other coments. The microfilm is available on request.

GIDEP operates according to a chartered agreement of the joint commanders of the Army Material Command, Air Force Logistics Command, and Air Force Systems Command. The program is administered through the Department of the Navy. GIDEP has over 400 participants of which approximately $80 \%$ are industrial organizations. The program enjoys a good participation by the nuclear industry and national laboratories.

Table F,1 (Appendix F) shows the major classifications of the GIDE! generic code and will give the reader an indication of the coverage dvailable in the GIDEP program. GIDEP publishes two documents of parcicular interest here: Sumciries of Failure Rate Data and Summaries of Replacement Rate Data. The failure rate data sumary includes the following information:

1. item name

2. participant code

3. Item identification number

4. vendor

5. observed envi.conment

6. application

7. stress level (stiess ratio, temperature, mechanical stress)

8. screening class (the extert to which items were screened prior to their installation or testing)

9. observation period

10. mean repair time

11. number of fallures

12. number of items

13. duration (total ficem experience)

14. fallure rate per million units of measure 
Wher iknow, failure mode information is include: in the data sumary listings as a subline to the listed line entry. Only the predoninant failure modes (generally the top three) are included. The number following the fallure node is the number of fallures attributid to that mode.

Included in the data sumary listings are group weans with 607 confidance intervals atout the group weans. Each confidence interval is compuied by using a nonparmetric noraal distribution around the man tiee t.c fallure from the group data. If fever than five ine entries or fifteen fallures were included in the group or the data were too variable, a confidence level is not computed. Where no failures occurred, 0.91 failures were assumed for calculating and showing a failure rate in the tabulateo data. Faflure rates calculated by this nethod are preceded by a less than (<) symbol. This method provides an upper $60 z$ confidence failure rate.

The replacentent rate data sumary contains essentially the sane information for replacemencs as opposed to failures.

\subsection{Evaluation - Advantages}

The GIDEP Failure Rate Data Interchange is a readily avallabit source for fallur: rates of a wide variety of items. A review of the data sumary indicates that nuclear particjpants are providing sose data. Th.s inclusion of failure mode Inforwation and failure rates for nonfailed components are definite assets.

\subsection{Evaiuation - Disadvantages}

Because GIDEP is a voluntary system, the quality of data appears to vary significantly between partict.pants' Inputs. But because the source can be determined, it is assumed that the quality of inputs can be verified.

Another disadvantage is in the "observed environment" category. Nine categories are listed; however, only one applies to the nuclear industry - "ground, fixed."

Finally, design recommendations for corrective action are net given and could not be expected because of the large number of data entries and participants.

\subsection{Avallability of Summaries}

Sumaries are avallable to all participants. Further information on participation and publications may be obtained from: 
Fallure Rs: : Dats Interchange Covenneat/Industry Dota Exchange Prograx Fleet Missile Systens Analysis and Evaluation Group Corona, Californis 91720

Telephone (714) 736-4677 
Append 1x A

LIQUID METAL EAGINEERING CENTER (LMEC) DATA 


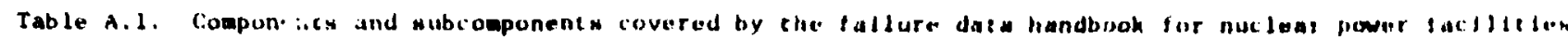

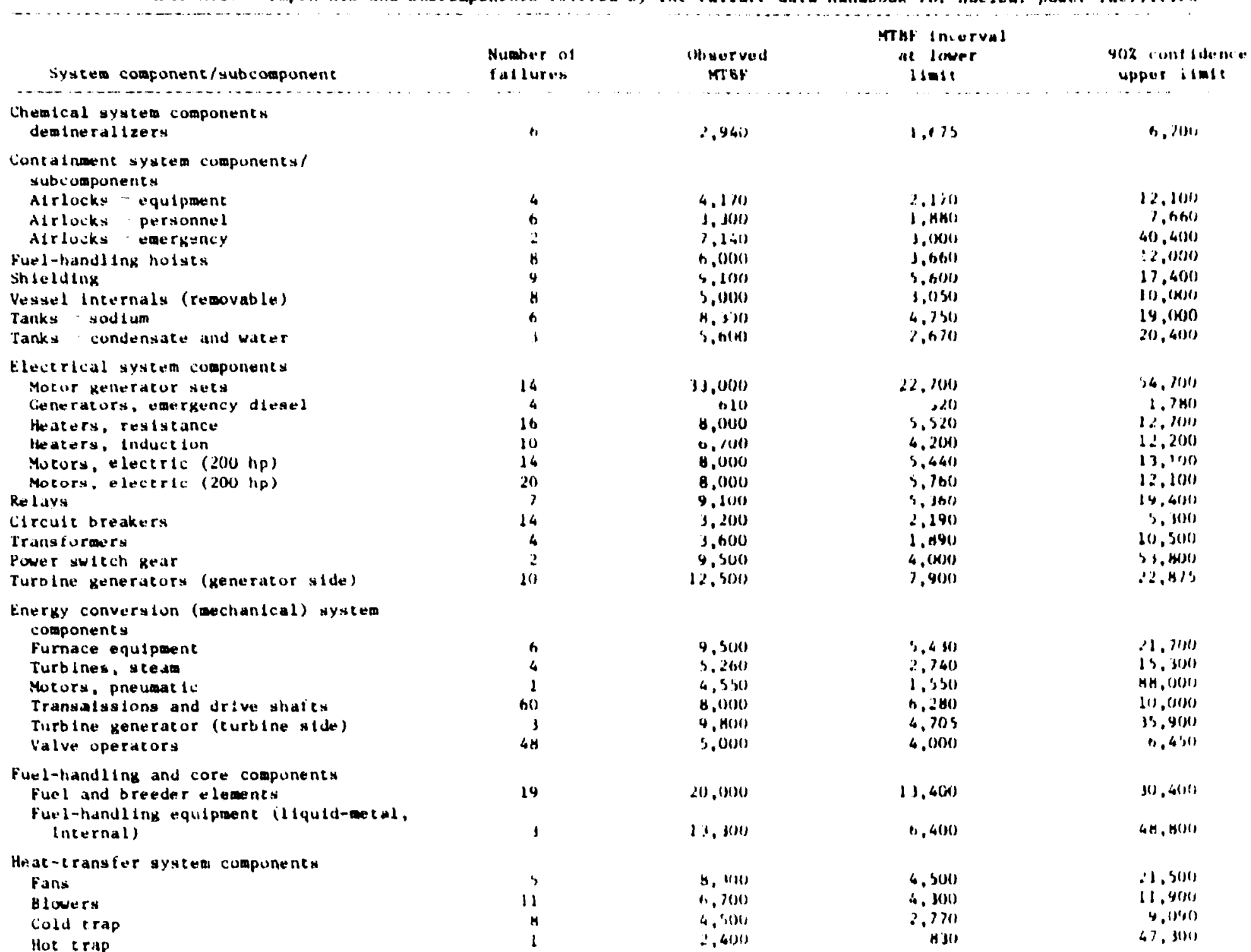


Tuble A.L (cont Inued)

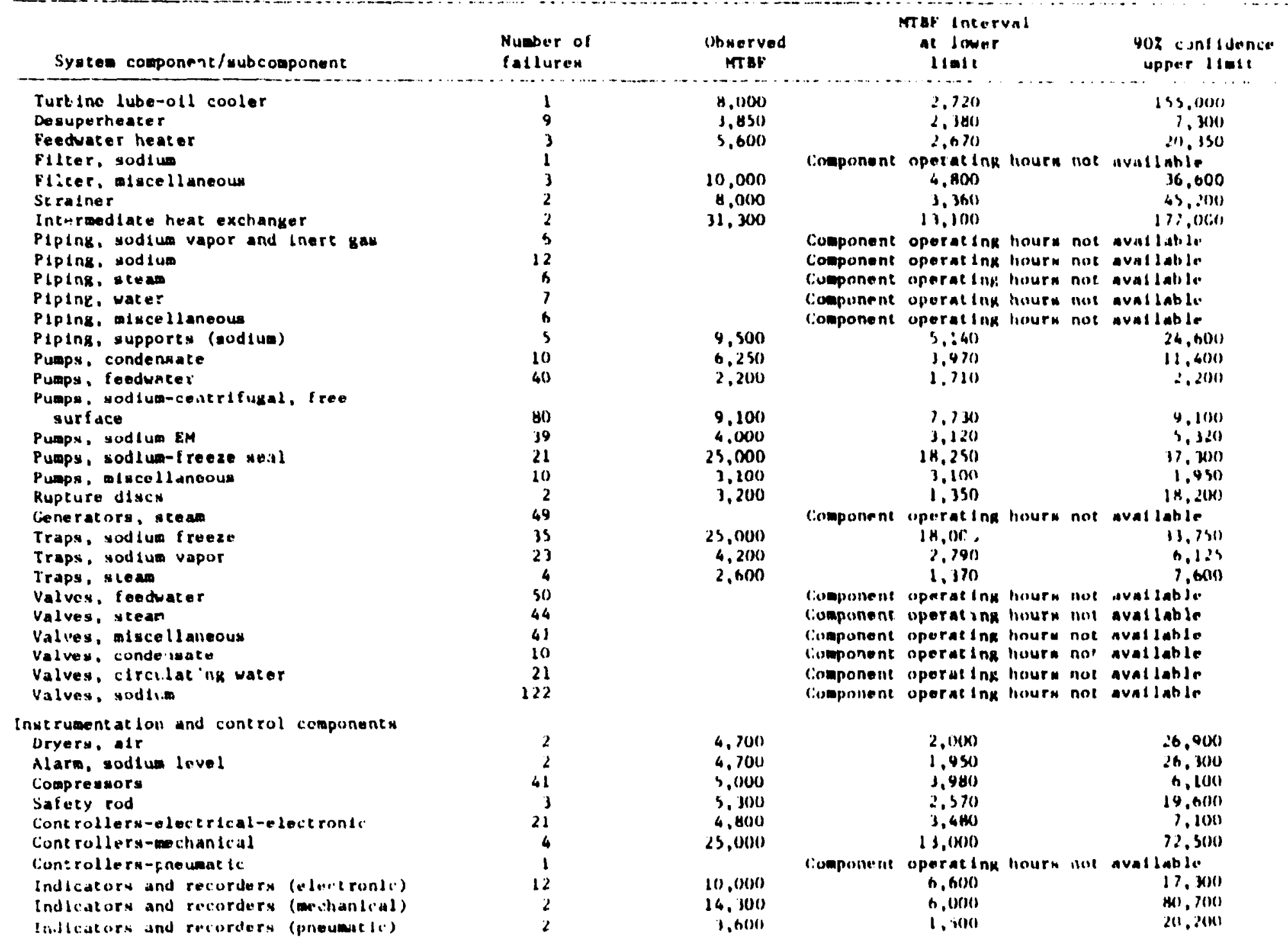


Tintole 1.1 (conclinumd)

System sumponant/vibicumponent

Indtcators and recurdery (wixhle xlines)

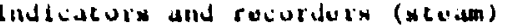

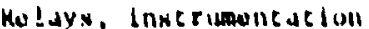

Neutron suarce

ieavurs tuiniecicure

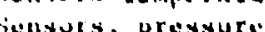

sellsuiv, roluctance and conducelvity

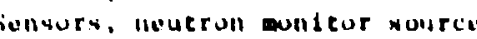

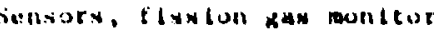

Witlink, power'

Wirlek, stand

Cunnetors

\begin{tabular}{|c|c|c|c|}
\hline $\begin{array}{l}\text { Numbur of } \\
\text { fallurux }\end{array}$ & $\begin{array}{l}\text { Dbaterved } \\
\text { MrHF }\end{array}$ & $\begin{array}{l}\text { MTBY Incorval } \\
\text { al lower } \\
\text { diale }\end{array}$ & 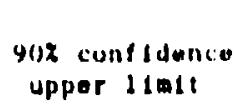 \\
\hline $\begin{array}{r}35 \\
1 \\
2 \\
1 \\
1 \\
11 \\
1 \\
4 \\
2 \\
4 \\
1\end{array}$ & $\begin{array}{r}1,400 \\
1,500 \\
1,600 \\
1,000 \\
6,7010 \\
3,6010 \\
11,100 \\
4,900 \\
16,700 \\
11,100 \\
16,700 \\
9,100\end{array}$ & $\begin{array}{l}2,750 \\
1,685 \\
1,530 \\
2,720 \\
1,200 \\
3,610 \\
9,330 \\
2,540 \\
7,000 \\
6,800 \\
8,000 \\
1,820\end{array}$ & $\begin{array}{r}4,110 \\
12,900 \\
20,6001 \\
125,000 \\
24,400 \\
9,900 \\
40,700 \\
14,100 \\
94,000 \\
21,000 \\
61,000 \\
51,000\end{array}$ \\
\hline
\end{tabular}




\section{Appendix B}

SYSTEYS RELAEILITY SERVICE DATA RNK (SVREI) DATA 


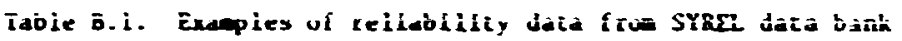

suiler ieed puss

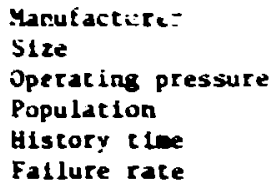

Industrlal as curbine

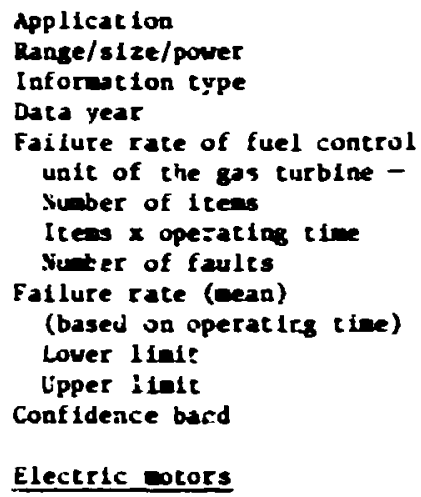

$7000 \mathrm{hp}$

2500 psts

$31 / 2$ years

6 faults per pup pet year

Average industrial

$6400 \mathrm{hp}$

Field, correctly reported

1970

3

20 ite-years

2

11.4 faulcs/10 $\mathrm{nr}$

1.38 faules $/ 10^{6}$ hr 41.2 falts $/ 10^{6} \mathrm{hr}$ $95 \%$

Three-phase notor for feed pup, frequency $60 \mathrm{cps}$.

$26 \mathrm{hp}, 415 \mathrm{~V}$

$x$

12

2.28 year's

27.4 ite-years

10 years

2

8. 33 faulte $/ 10^{6}$ hr

30.1 faules $/ 10^{6} \mathrm{hr}$

1.01 faulcs $/ 10^{6} \mathrm{hr}$

957

Potseon

Average industrial

Field, correctly reported

Nuclear reacrior pertod acter weth trip facility

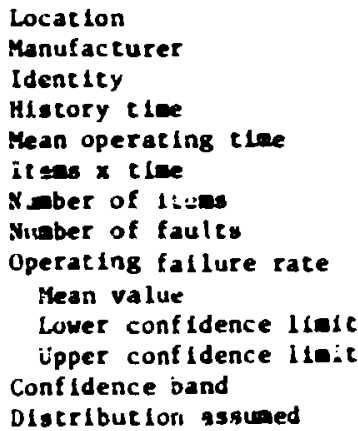

$6000 \mathrm{hp}$

$2500 \mathrm{pstg}$

10

5.1 years

4 faults per punp

per year

inged 
Table B.I (continued)

Irensistur, silicon, pnp, planar

Manuf ac turer

Ident ity

History time

D

Mean operating ciee

Nuber of icens

suaber of fauics

Itees $x$ tine

Operating failure rate

Mean value

Lower conf idence linte

Upper confidence lialt

Confidence band

Distribution assued

2712

$12,600 \mathrm{hr}$

$2,160 \mathrm{hr}$

1088

9

$2,350,000$ icen-hr

3.82 faules $/ 10^{6} \mathrm{he}$

1.75 faules $/ 10^{6} \mathrm{hr}$

7.28 faules $/ 10^{6} \mathrm{hr}$

952

Exponential

Diode, rectifier, silicon

Hanufacturer

Identity

Hiscory tiee

Mean operating tine

Nubber of ltens

Nuber of faults

Icens $x$ operat ins tine

Operating fallure rate

c

25701

11,300 he

$1980 \mathrm{hr}$

1440

1

2,800,000 iter-hr

0.357 faules/ $10^{6}$ hr (ean) 
Table B.2. SYRFL Reliability Data Store (itees for which there is at least one reliability entry in the data stere):

\begin{tabular}{|c|c|}
\hline 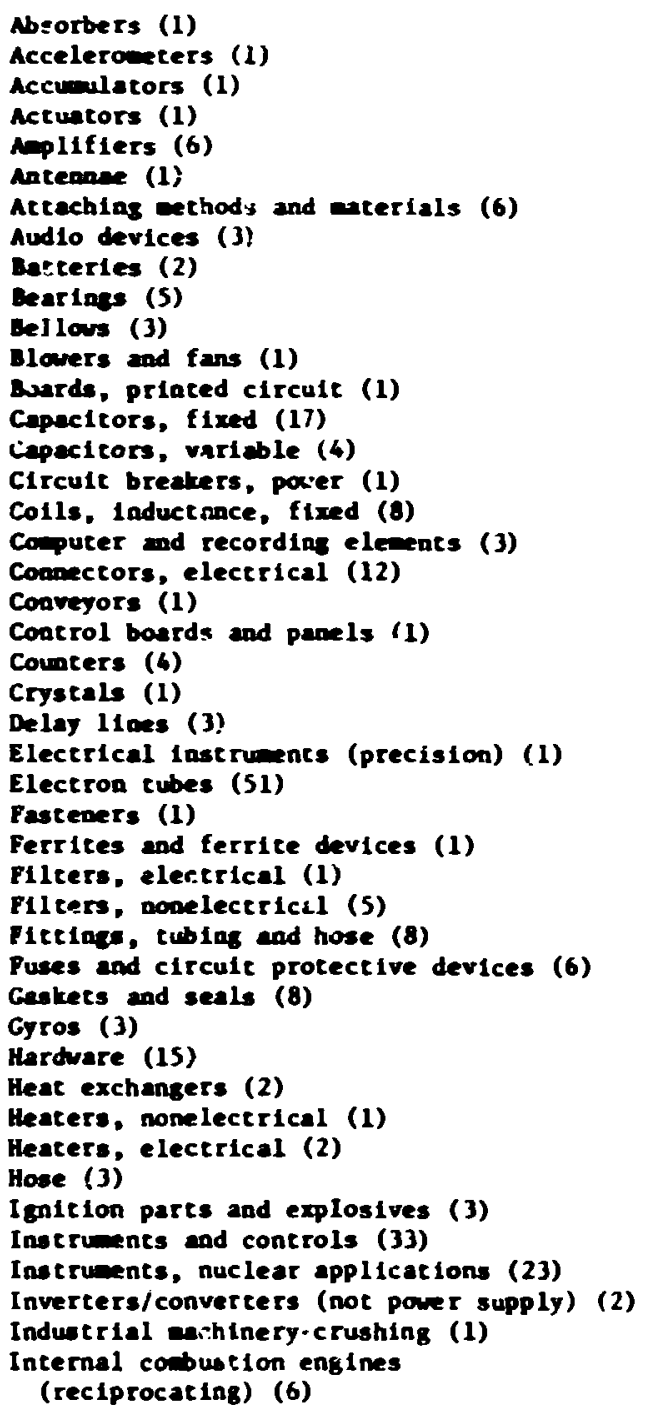 & 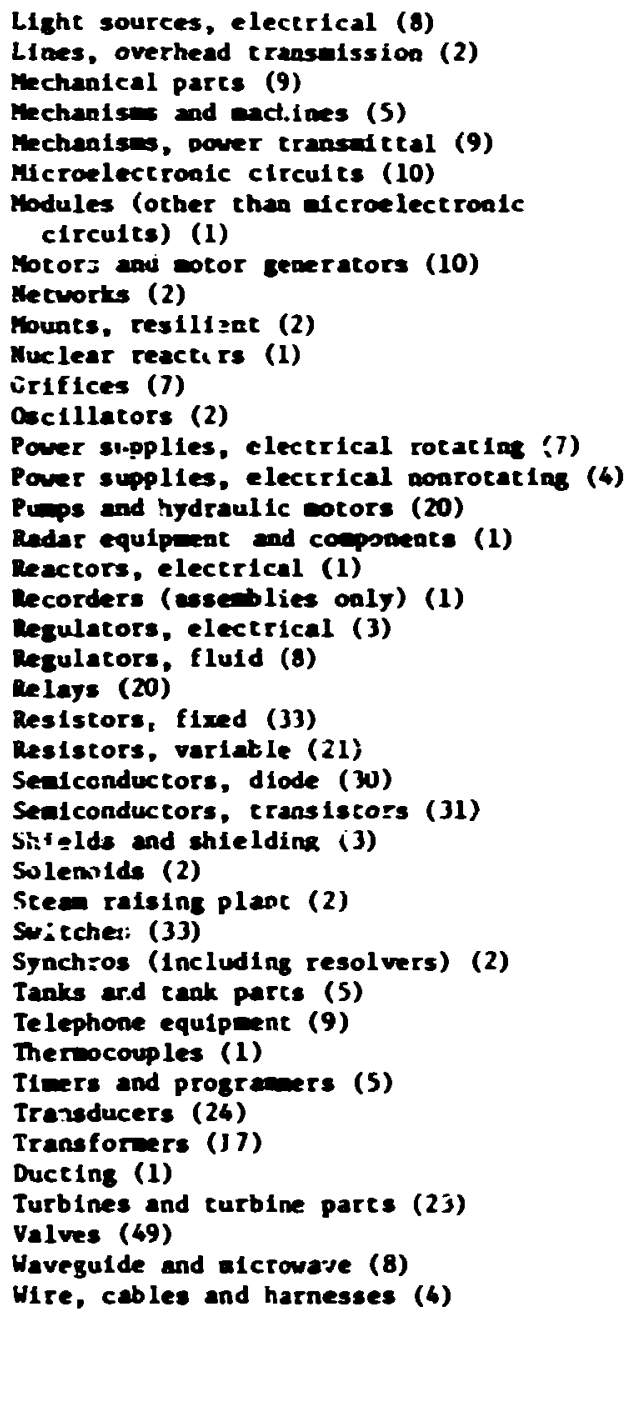 \\
\hline
\end{tabular}

Numers in parentheses indicate the number of subcategories under each conponent cype; for exaple, valye (j) indicates bleed, bypass, check, check air aedia, check water media. 
Appendix C

WASH-1400 SUMEARY DATA 
Table C.1. Summary of aseesements for mechanical hardwere and comperioon with nuclear experience

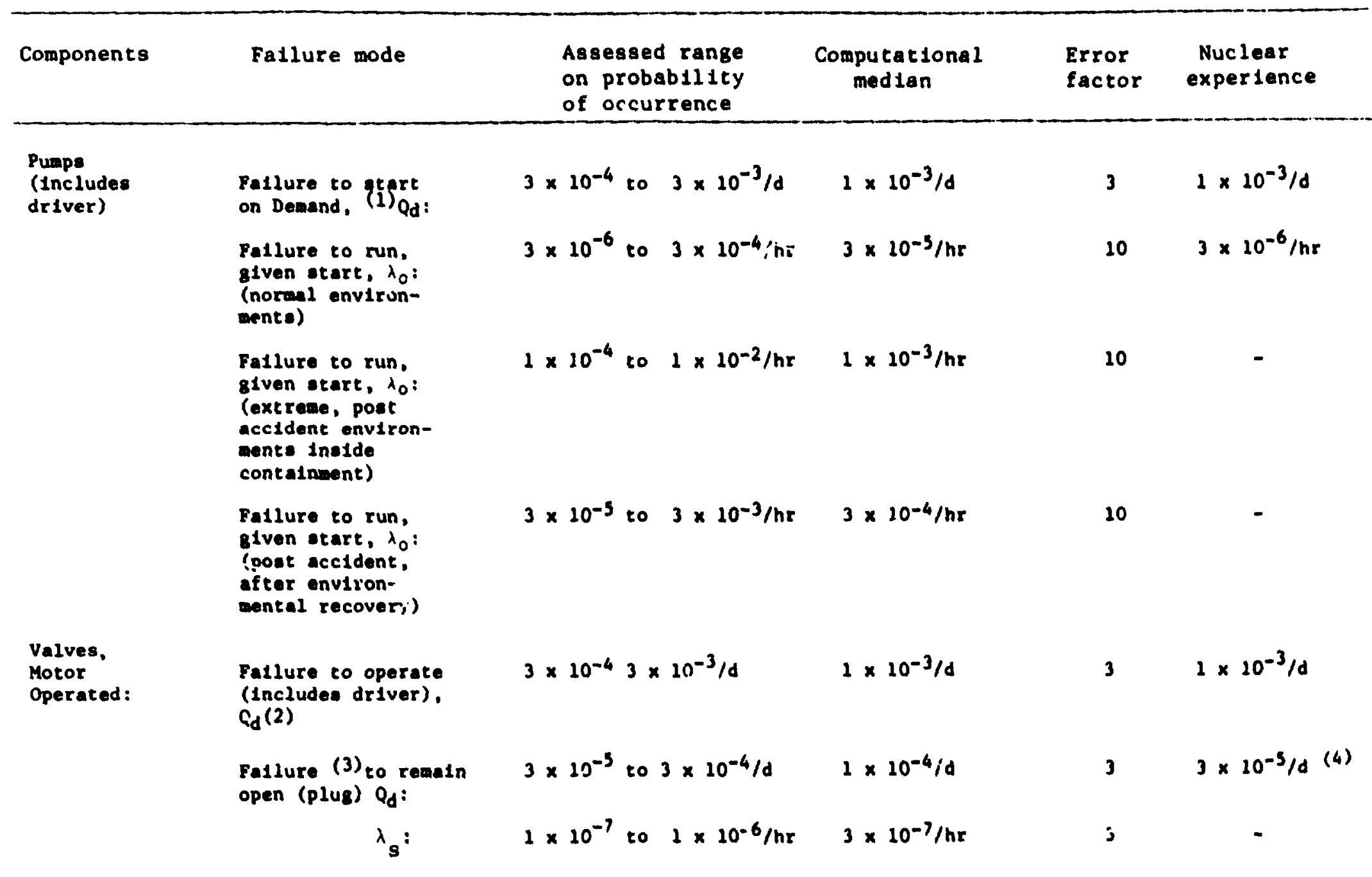


Table C.1 (continuad)

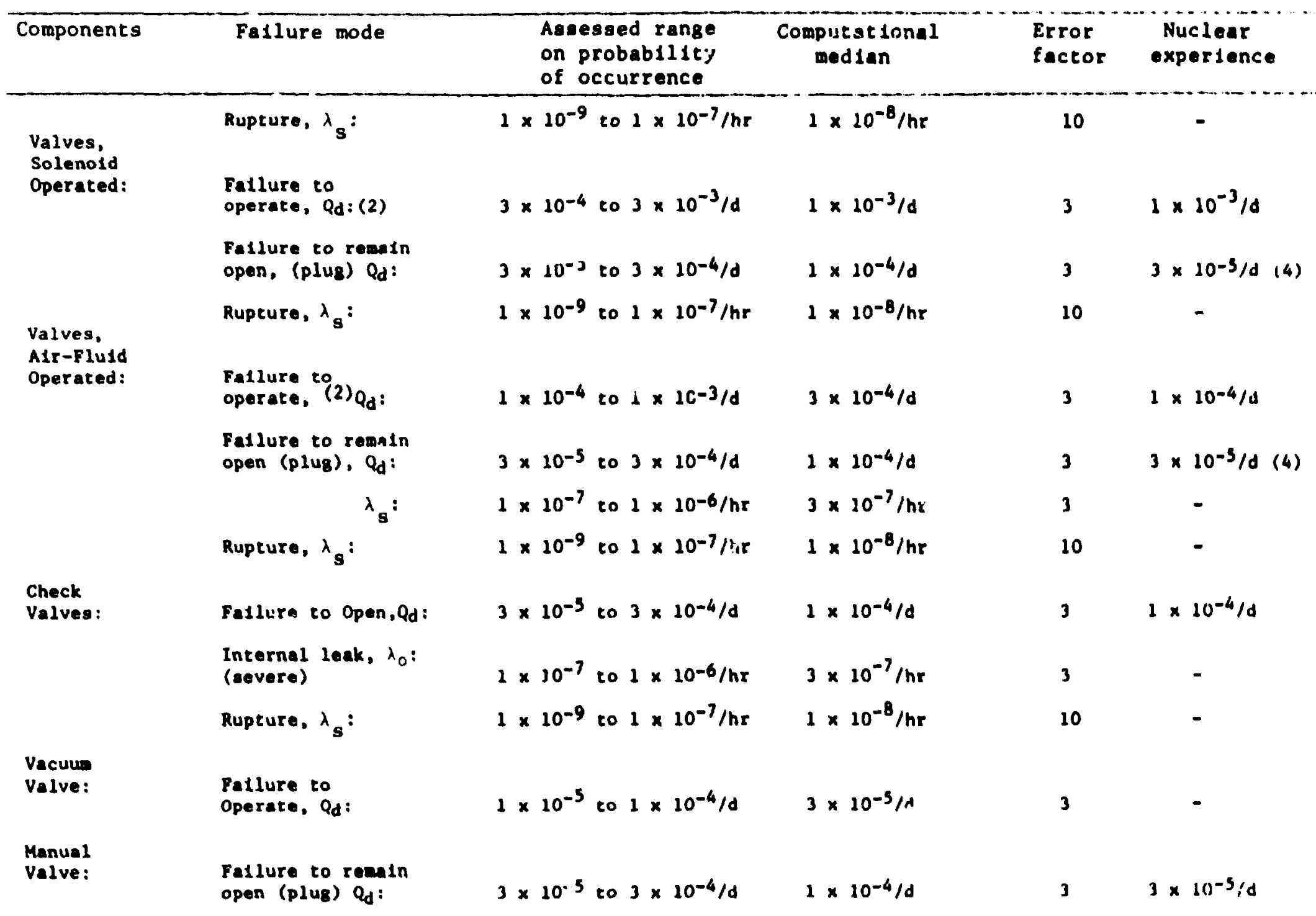


Table C.1 (continued)

\begin{tabular}{|c|c|c|c|c|c|}
\hline Components & Fallure mode & $\begin{array}{l}\text { Assessed range } \\
\text { on probability } \\
\text { of occurrence }\end{array}$ & $\begin{array}{l}\text { Computat Ional } \\
\text { medien }\end{array}$ & $\begin{array}{l}\text { Error } \\
\text { factor }\end{array}$ & $\begin{array}{l}\text { Nuclear } \\
\text { expertence }\end{array}$ \\
\hline & Rupture, $\lambda_{s}$ : & $1 \times 10^{-9}$ to $1 \times 10^{-7} / \mathrm{hr}$ & $1 \times 10^{-8} / \mathrm{hr}$ & 10 & - \\
\hline \multirow[t]{2}{*}{ Rellef Valves } & $\begin{array}{l}\text { Falls to open, } \\
Q_{d}:\end{array}$ & $3 \times 10^{-6}$ to $3 \times 10^{-5} / \mathrm{d}$ & $1 \times 10^{-5} / d$ & 3 & $1 \times 10^{-5} / d$ \\
\hline & $\begin{array}{l}\text { Premature open, } \\
\lambda_{0}:\end{array}$ & $3 \times 10^{-6}$ to $3 \times 10^{-5} / \mathrm{hr}$ & $1 \times 10^{-5} / \mathrm{hr}$ & 3 & - \\
\hline $\begin{array}{l}\text { Test } \\
\text { Valves, } \\
\text { Flow Meters, } \\
\text { Orifices }\end{array}$ & $\begin{array}{l}\text { Fallure to rema in } \\
\text { open (plup), } Q_{d} \text { : }\end{array}$ & $1 \times 10^{-4}$ to $1 \times 10^{-3} / \mathrm{d}$ & $3 \times 10^{-4 / d}$ & 3 & - \\
\hline & Rupture, $\lambda_{\mathrm{s}}$, & $1 \times 10^{-9}$ to $1 \times 10^{.7} / \mathrm{hr}$ & $1 \times 10^{-8} / \mathrm{hr}$ & 10 & - \\
\hline \multicolumn{6}{|l|}{ P1pes } \\
\hline $\begin{array}{l}\text { Plpe } \leq 3^{\prime \prime} \\
\text { d1a. per } \\
\text { section }\end{array}$ & $\begin{array}{l}\text { Rupture/Plug. } \\
\lambda_{s}, \lambda_{0}\end{array}$ & $3 \times 10^{-11}$ to $3 \times 10^{-8} / \mathrm{hr}$ & $1 \times 10^{-9} / \mathrm{hr}$ & 30 & $2 \times 10^{-9} / \mathrm{hr}$ \\
\hline $\begin{array}{l}\text { Pipe > 3" } \\
\text { dia. per } \\
\text { section }\end{array}$ & $\begin{array}{l}\text { Rupture, } \\
\lambda_{s}, \lambda_{0}\end{array}$ & $3 \times 10^{-12}$ to $3 \times 10^{-9} / \mathrm{hr}$ & $1 \times 10^{-10} / \mathrm{hr}$ & 30 & $1 \times 10^{-10} / \mathrm{hr}$ \\
\hline $\begin{array}{l}\text { Clutch, } \\
\text { wechanical }\end{array}$ & $\begin{array}{l}\text { Fallure to } \\
\text { operate, } Q_{d}:(1)\end{array}$ & $1 \times 10^{-4}$ co $1 \times 10^{-3} / d$ & $3 \times 10^{-4} / d$ & 3 & $3 \times 10^{-4 / d}$ \\
\hline $\begin{array}{l}\text { Scram Rods } \\
\text { (single) }\end{array}$ & Fallure to Insert & $3 \times 10^{-5}$ to $3 \times 10^{-4} / d$ & $1 \times 10^{-4 / d}$ & 3 & - \\
\hline
\end{tabular}


Table C.I (continued)

(1) Deand probabillties are taced on the presence of proper Input control elenale. Por turbina driven piupe the affect of fallures of valves, sensors and othar aux1liary hardware may reeult in elent-

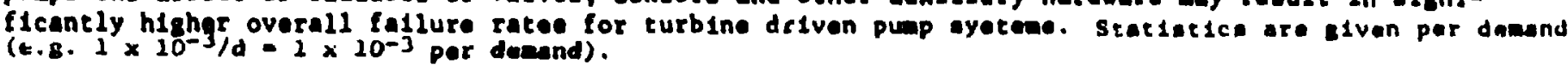

(2) Demant probabilities are based on presence of proper input control sisnale.

(3) Plug probebilitlea are given in damand probability, and par hour rates, ince phenomene are cenerally twe dependent, but plugzed condition aay only be detected upon a dasane of the eyotan.

(4) Approximated froe plugging that was detected. 
Table C.2. Summary of assessments for electrical equipment and comparison with nuclear experience

\begin{tabular}{|c|c|c|c|c|c|}
\hline Component & Fallure mode & Assessed range & $\begin{array}{l}\text { Computatiolial } \\
\text { median }\end{array}$ & $\begin{array}{l}\text { Error } \\
\text { factor }\end{array}$ & $\begin{array}{l}\text { Nuclear } \\
\text { experience }\end{array}$ \\
\hline \multirow[t]{2}{*}{$\begin{array}{l}\text { Clutch, } \\
\text { Electrical }\end{array}$} & $\begin{array}{l}\text { Fallure to } \\
\text { operate, }{ }^{\star Q_{d}} \text { : }\end{array}$ & $1 \times 10^{-4}$ to $1 \times 10^{-3} / \mathrm{d}$ & $3 \times 20^{-4} / \mathrm{d}$ & 3 & - \\
\hline & $\begin{array}{l}\text { Premature dis- } \\
\text { engagement, } \lambda_{0}:\end{array}$ & $1 \times 10^{-7}$ to $1 \times 10^{-5} / \mathrm{hr}$ & $1 \times 10^{-6} / \mathrm{hr}$ & 10 & - \\
\hline \multirow[t]{3}{*}{$\begin{array}{l}\text { Motors, } \\
\text { Electric }\end{array}$} & $\begin{array}{l}\text { Fallure to start, } \\
\text { NQ } Q_{d}:\end{array}$ & $1: 10^{-4}$ to $1 \times 10^{-3} / d$ & $3 \times 10^{-4} / \mathrm{d}$ & 3 & $3 \times 10^{-4} / 4$ \\
\hline & $\begin{array}{l}\text { Fallure to run, } \\
\text { given start, } \lambda \text { : } \\
\text { (normal envirsn- } \\
\text { ment) }\end{array}$ & $3 \times 10^{-6}$ to $10^{-5} / \mathrm{hr}$ & $1 \times 10^{-5} / \mathrm{hr}$ & 3 & $1: 10^{.6} / \mathrm{hr}^{(1)}$ \\
\hline & $\begin{array}{l}\text { Fallure to run, } \\
\text { given start, } \lambda{ }^{\prime} \text { : } \\
\text { (extreme envi- } \\
\text { roment) }\end{array}$ & $1 \times 10^{-4}$ to $1 \times 10^{-2} / \mathrm{hr}$ & $1 \times 10^{-3} / \mathrm{hr}$ & 10 & - \\
\hline \multirow[t]{2}{*}{ Relays } & $\begin{array}{l}\text { Fallure to } \\
\text { energize, } Q_{D} \text { : }\end{array}$ & $3 \times 10^{-5}$ to $3 \times 10^{-4} / \mathrm{d}$ & $1 \times 10^{-4} / \mathrm{d}$ & 3 & $3 \times 10^{-5} / d$ \\
\hline & $\begin{array}{l}\text { Fallure of NO } \\
\text { contacts to close, } \\
\text { glven snergized, } \\
\lambda_{0}:\end{array}$ & $1 \times 10^{-7}$ to $1 \times 10^{-6} / \mathrm{hr}$ & $3 \times 10^{-7} / \mathrm{hr}$ & 3 & - \\
\hline
\end{tabular}


Table C. 2 (continued)

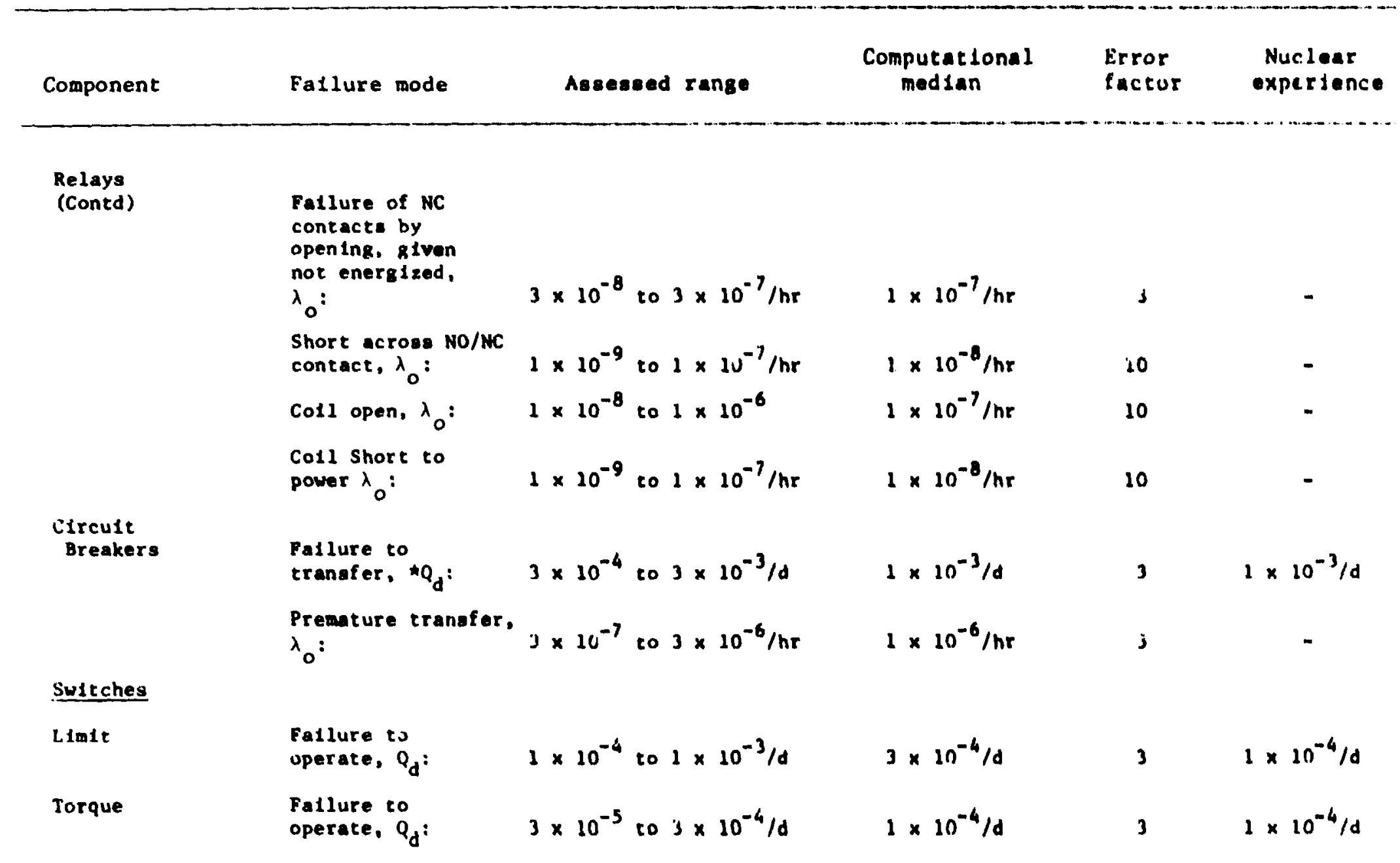


Table C.2 (continued)

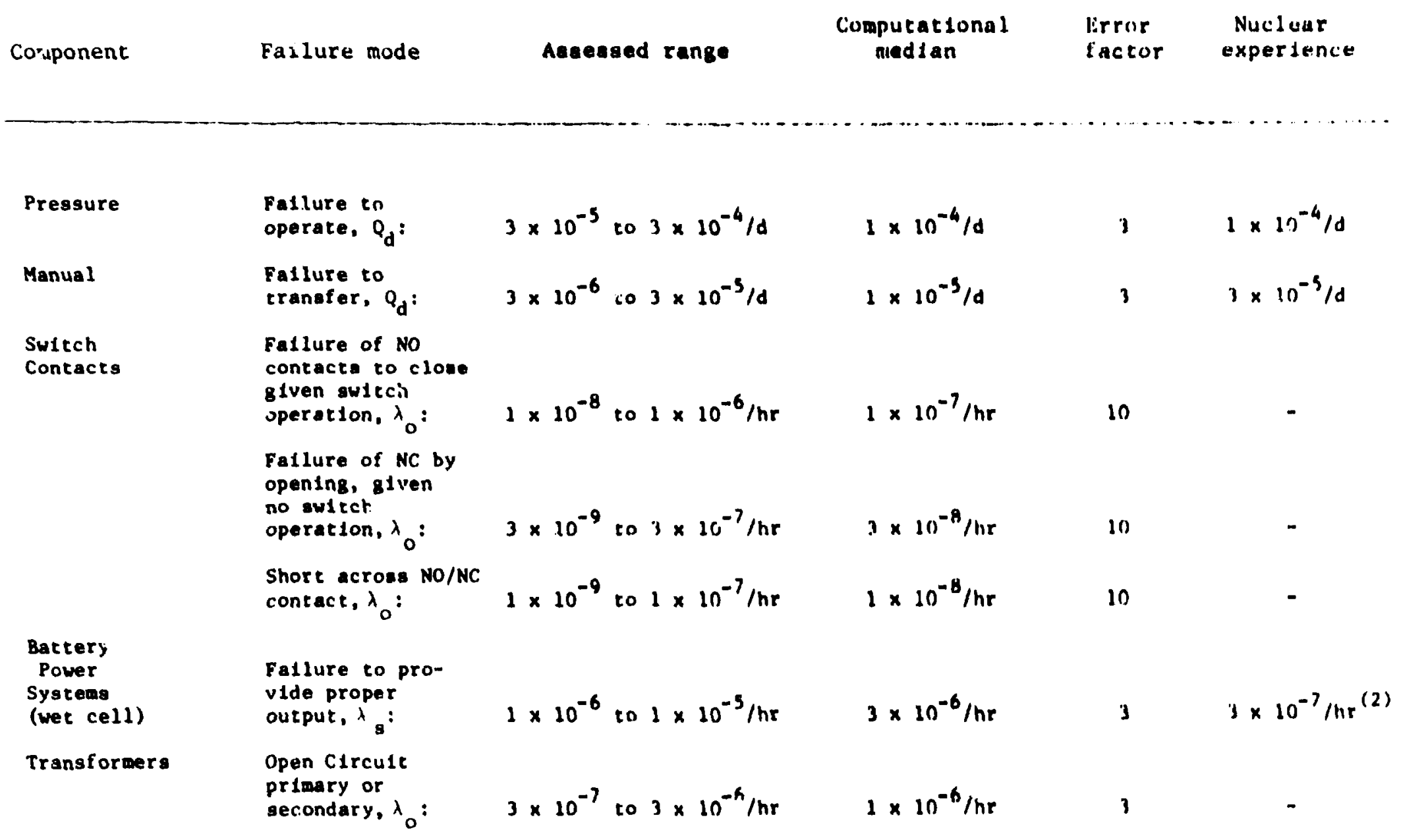


Table C.2 (continued)

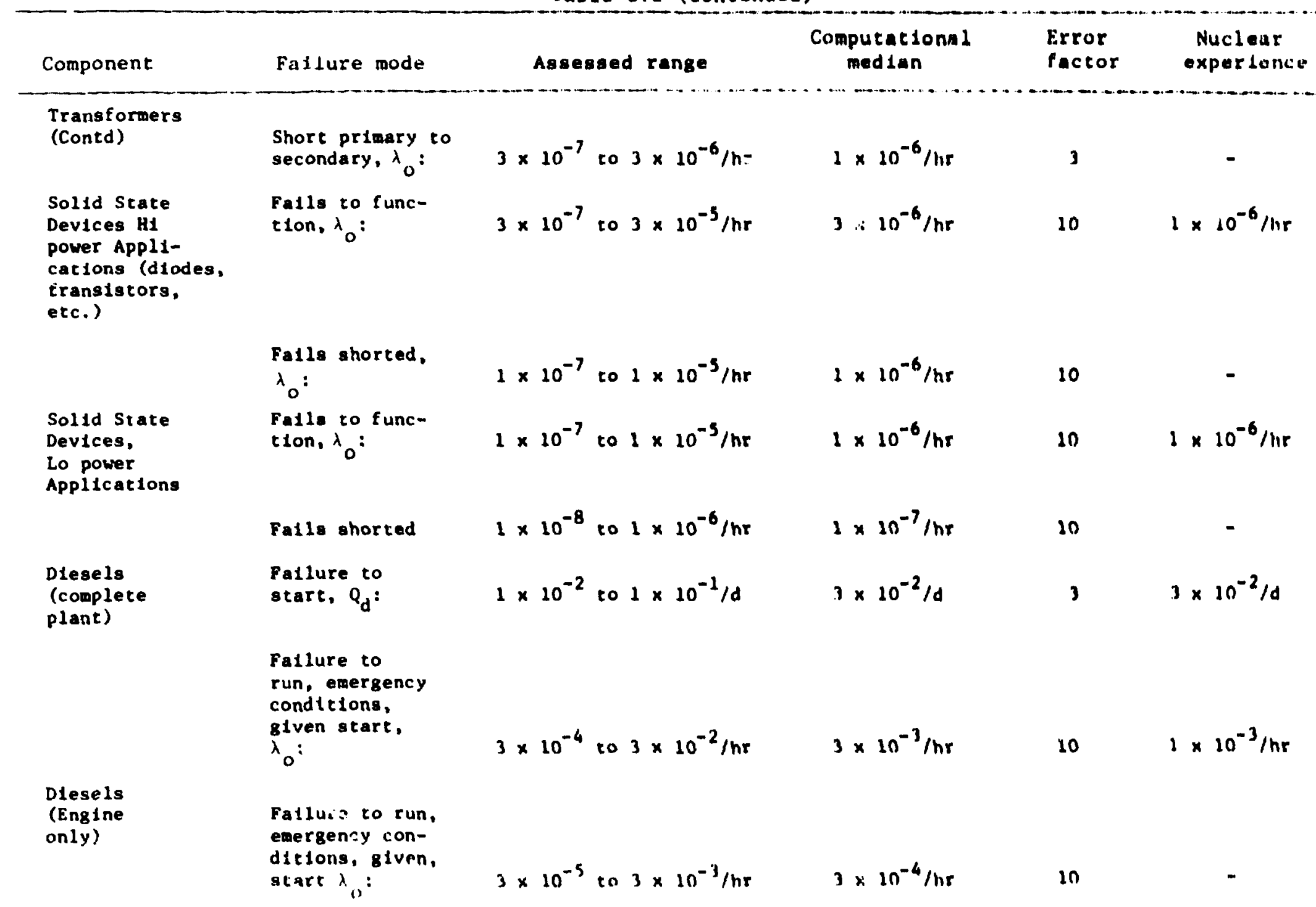


Table C.2 (coneinued)

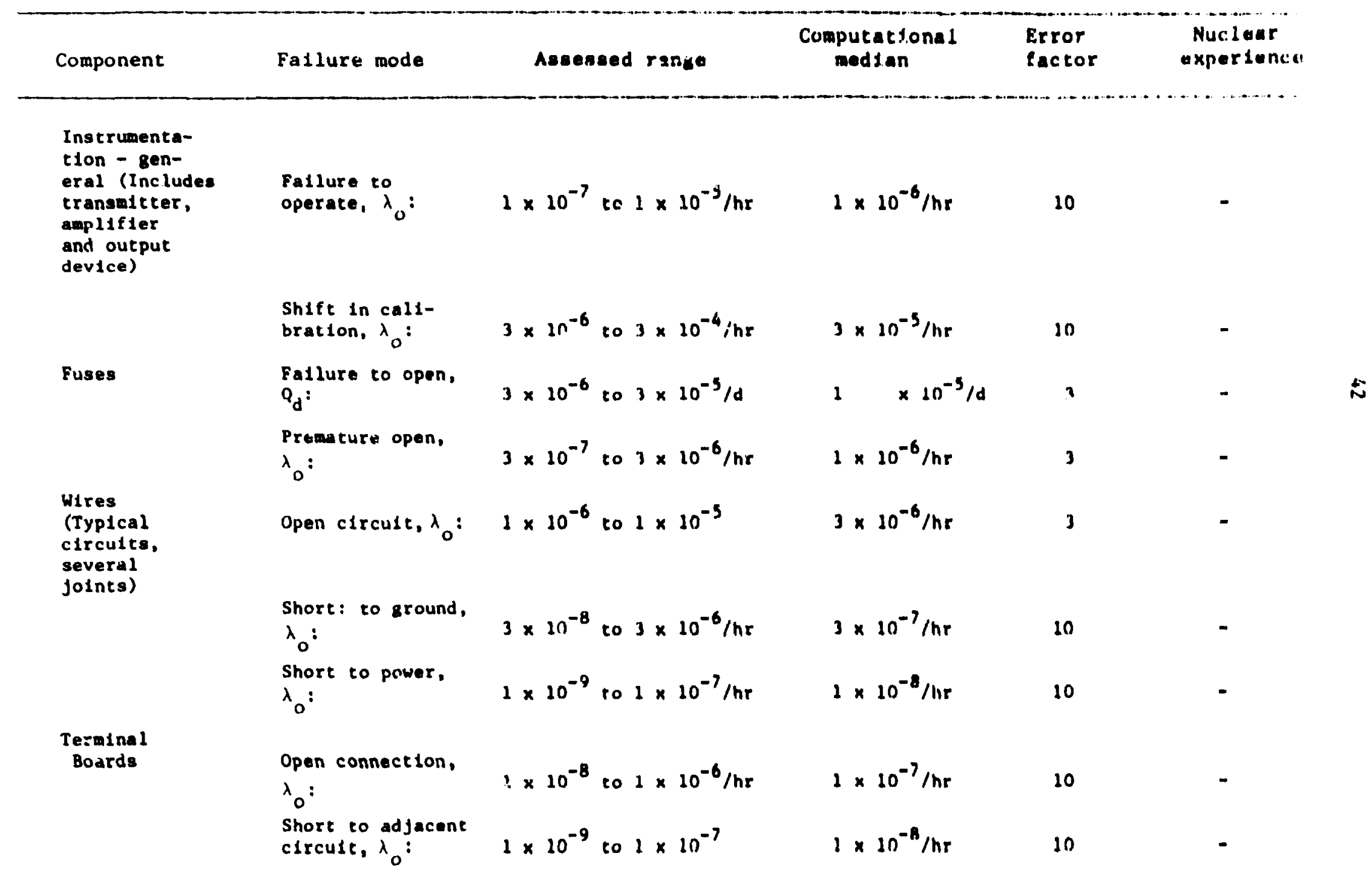


Table C.2 (continued)

tDemand probabllitles are based on presence of proper lnput control elgnala. Rutus aru aiven por demand.

(1) Derived from combined atandby and oporated aata.

(2) Derived from standby test of batterles, whlch does not includa lond. 
Table C.3. Comparison of assessed ranges of failure data with raw data from various sources

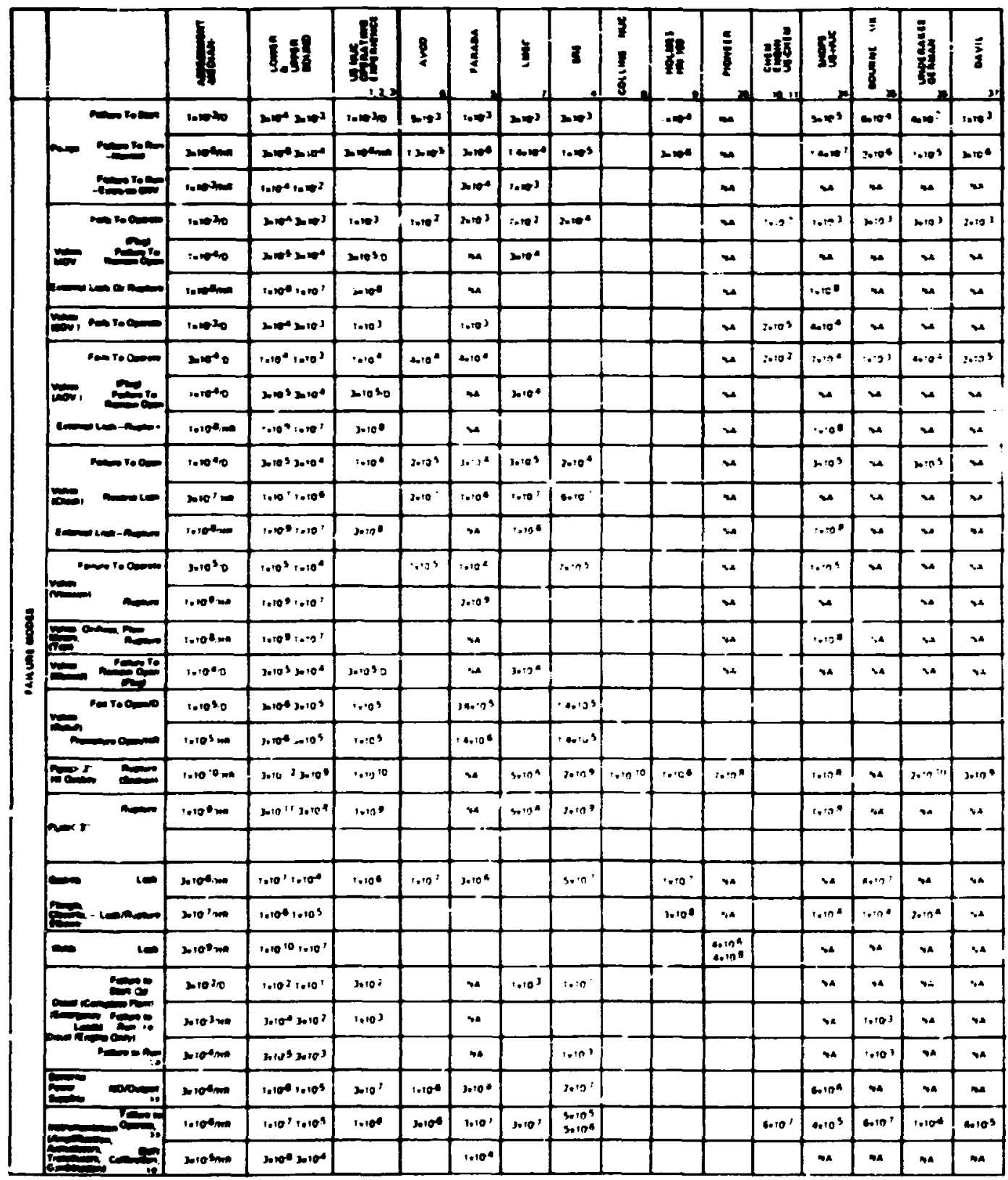


Table C. 3 (continued)

\begin{tabular}{|c|c|c|c|c|c|c|c|c|c|c|c|c|c|c|c|c|c|}
\hline & ent & 8 & $\underset{t}{\mathbf{n}}$ & 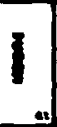 & 政 & 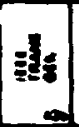 & 3 & $\mathbf{E}$ & $33_{3}$ & $\underline{\underline{S}}$ & 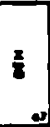 & $\overline{\mathbf{b}}_{z}$ & 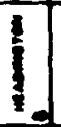 & $\bar{z}$ & & & 1 \\
\hline & - & $\because m$ & - & - & $=$ & - & - & |مس & $m$ & $\infty$ & $=$ & - & 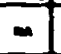 & $m$ & - & - & \\
\hline & |+口, & (م) & - & - & 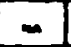 & - & - & |مس & $=$ & - & - & - & - & $=$ & 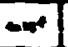 & & \\
\hline 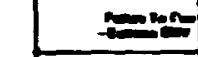 & $=$ & $m$ & 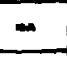 & $=$ & $=$ & $=$ & $=$ & & - & - & - & - & $=$ & $=$ & $m$ & - & (n) \\
\hline & - & $+\infty 1$ & - & $\rightarrow \infty$ & $m$ & $=$ & 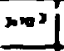 & $i \infty$ & - & $m$ & $=$ & - & $=$ & - & 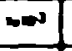 & $2 n$ & $\infty$ \\
\hline & - & 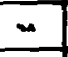 & 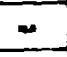 & $n$ & 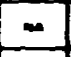 & 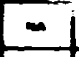 & $=$ & - & $=$ & - & - & - & $=$ & $=$ & $\infty+\infty$ & & $=$ \\
\hline & - & 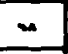 & $\cdots$ & $\sim$ & $=$ & $\approx$ & $=$ & - & - & $\infty$ & $\infty$ & - & $\sim$ & - & $m$ & - & אם. \\
\hline$E$ & - & $\approx$ & 4 & - & - & 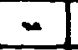 & $2 m$ & - & - & $\cdots$ & - & - & - & - & $i^{2}=2$ & & Son \\
\hline & - & $n$ & $\approx$ & 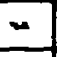 & 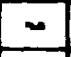 & 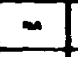 & $=$ & - & $m$ & $\cdots$ & -1 & 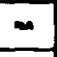 & 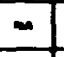 & $=$ & - & $=$ & {[} \\
\hline & 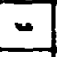 & $\sim$ & $\infty$ & $n$ & $x$ & 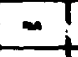 & 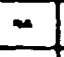 & $\because$ & $=$ & $m$ & -1 & $m$ & $=$ & $m$ & $=$ & - & $\infty$ \\
\hline- & 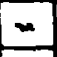 & 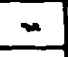 & $=$ & $\approx$ & $\approx$ & $\approx$ & $=$ & $=$ & $\approx$ & $=$ & $=$ & $\infty$ & $=$ & $=$ & $=$ & 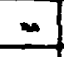 & \\
\hline & 2 & $\sim$ & 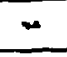 & $\therefore$ & 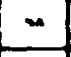 & $\Sigma$ & $=$ & 2 & $=$ & - & $m$ & $m$ & 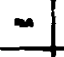 & $=$ & $2 n+1$ & & $m$ \\
\hline & 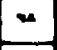 & $\sim$ & 2 & $\infty$ & $\infty$ & 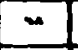 & $\infty$ & $\therefore$ & $\cdots$ & $=$ & $m$ & - & - & 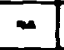 & $m$ & $n$ & \\
\hline- & - & 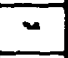 & $\therefore$ & $\infty$ & - & $=$ & $\sim$ & 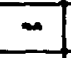 & 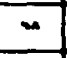 & $=$ & - & $\approx$ & $=$ & $=$ & $=$ & - & $8-\infty$ \\
\hline & 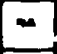 & $\therefore$ & 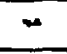 & - & - & 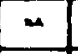 & $=$ & $m$ & $m$ & $m$ & $=$ & - & - & - & 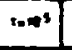 & & $\infty$ \\
\hline & - & $=$ & $\omega$ & - & + & - & - & - & 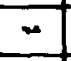 & $=$ & - & $-\infty$ & 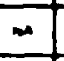 & 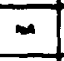 & - & $\sim$ & 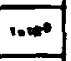 \\
\hline$=$ & 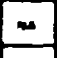 & 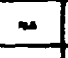 & 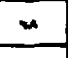 & $m$ & $n$ & $\Delta$ & $\omega$ & $m$ & . & $m$ & - & - & - & $n$ & $\infty$ & & - \\
\hline$=\frac{x^{2}}{2}$ & $\infty$ & $\sim$ & $\cdots$ & - & 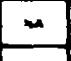 & $\sim$ & " & - & $n$ & - & - & - & $=$ & 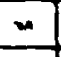 & $m$ & $m$ & - \\
\hline ond. & & & & & & & & & & & & & & & & & 1.08 \\
\hline 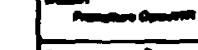 & & & & & & & & & & & & & & & & & .0 .103 \\
\hline$r 2$ & $=$ & $n$ & $\because$ & $\cdots$ & 1,000 & 100 & 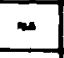 & $\infty$ & $=$ & 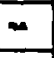 & $\sim$ & $n$ & $\sim$ & $\approx$ & $\sim$ & $=$ & ineng \\
\hline & 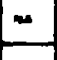 & 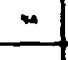 & $x$ & $n$ & 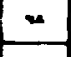 & $\sim$ & 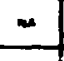 & $n$ & $m$ & $*$ & 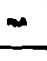 & 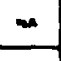 & 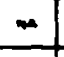 & $\infty$ & $\sim$ & - & . \\
\hline & 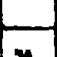 & u & 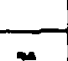 & $y$ & * & $\approx$ & ? & & $M$ & $\pi$ & - & $\sim$ & $\pi$ & $=$ & & $x, \log$ & \\
\hline$\equiv$ & - & $m$ & - & $\sim$ & $\infty$ & n.10' & $n$ & $\sim$ & $\infty$ & $n$ & $\pi$ & $\infty$ & - & $m$ & & $\sin _{x \rightarrow \infty}$ & \\
\hline & $=$ & $*$ & $=$ & $m$ & $\because$ & $=$ & $=$ & 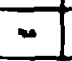 & -1 & - & $\infty$ & $\approx$ & $n$ & $\omega$ & $\omega$ & $\sim$ & $\therefore$ \\
\hline 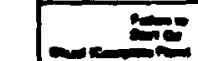 & - & $*$ & $m$ & $n$ & $\infty$ & 1.08 & - & - & $\infty$ & 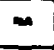 & 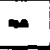 & $m$ & $=$ & $m$ & $\cdots$ & $\cdots$ & 0.00 \\
\hline & $m$ & - & 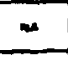 & $-\infty$ & $=$ & 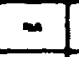 & $\approx$ & $=$ & $m$ & - & $m$ & $m$ & - & $m$ & $\infty$ & - & $. \infty+\infty$ \\
\hline & $\cdots$ & 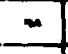 & $n$ & $\pi$ & $\infty$ & $n$ & 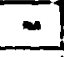 & $\cdots$ & $\cdots$ & $m$ & $m$ & $n$ & $m$ & $m$ & $m$ & - & $\operatorname{ron} 0$ \\
\hline$E$ & - & $\sim$ & $=$ & $\sim$ & $\approx$ & $=$ & -1 & $m$ & $\infty$ & $m$ & $m$ & $m$ & $\cdots$ & -1 & $m$ & $\infty$ & 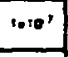 \\
\hline & $n$ & $\cdots$ & noto5 & no' & $\infty$ & 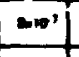 & $m$ & $\infty$ & Non & $m$ & $m$ & $n$ & $=109$ & $n+0^{5}$ & $\cdots$ & $m$ & 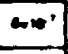 \\
\hline$\Rightarrow \cos 3$ & $\infty$ & $m$ & 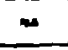 & $m$ & 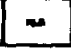 & 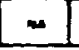 & $m$ & - & $\approx$ & $\infty$ & $m$ & $m$ & $m$ & $\sim$ & $m$ & - & $n \rightarrow \infty$ \\
\hline
\end{tabular}


Table C. 3 (continued)

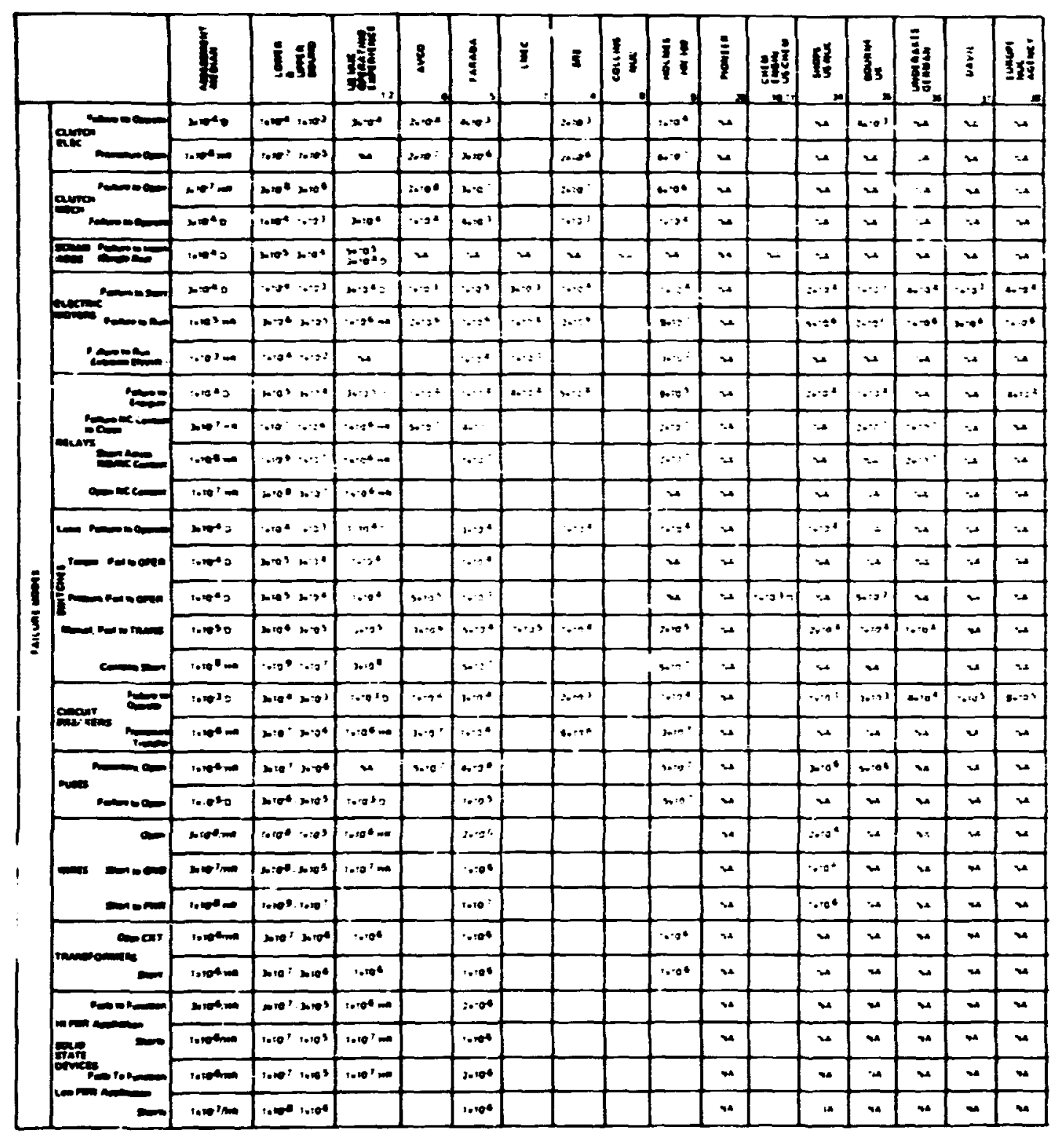


Table C.3 (continued)

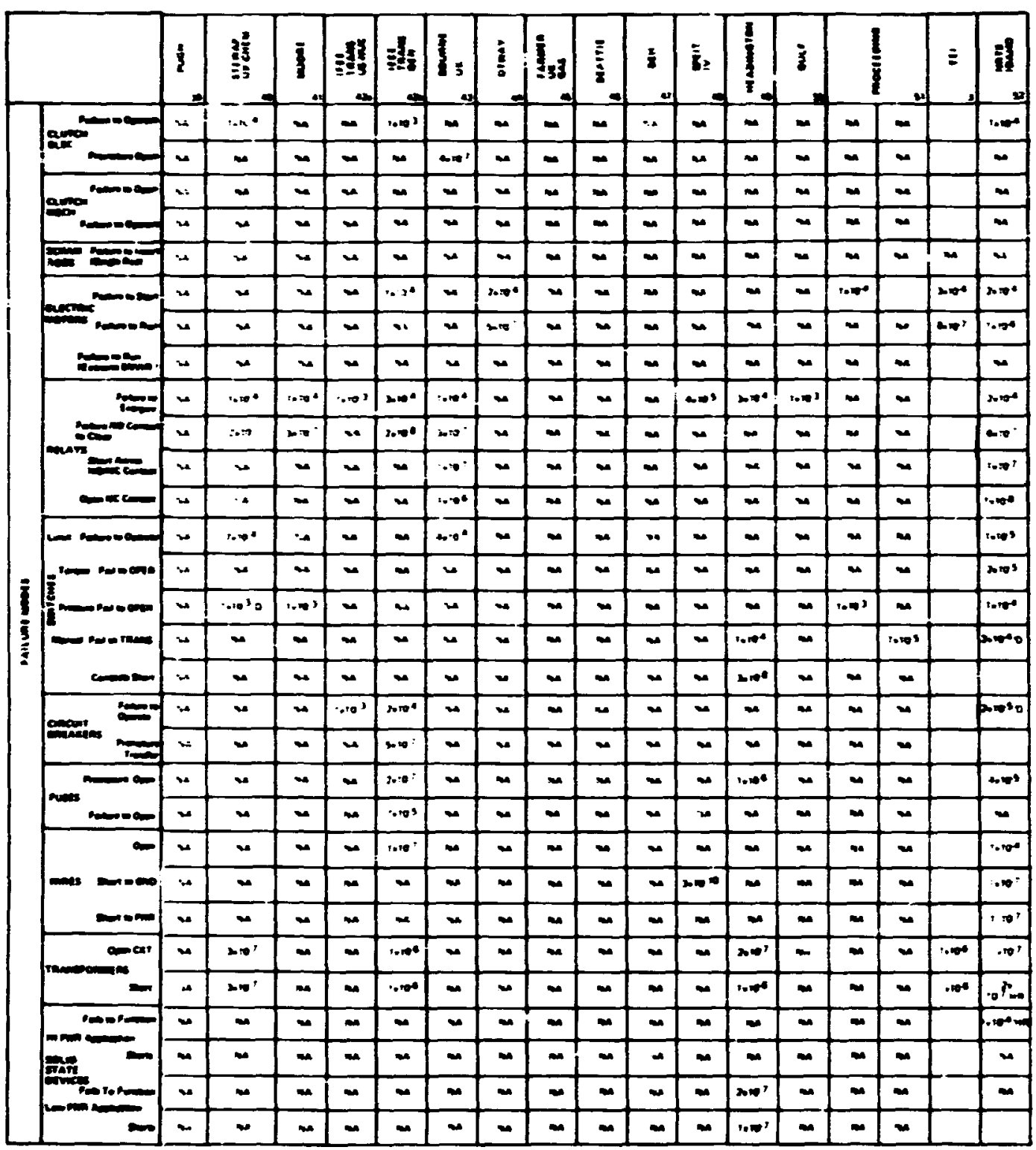


Appendix D

MAVAL SAIP EJGINEERING CaTtER (MAVSEC) RAE DATA BANK 
BLANK PAGE 


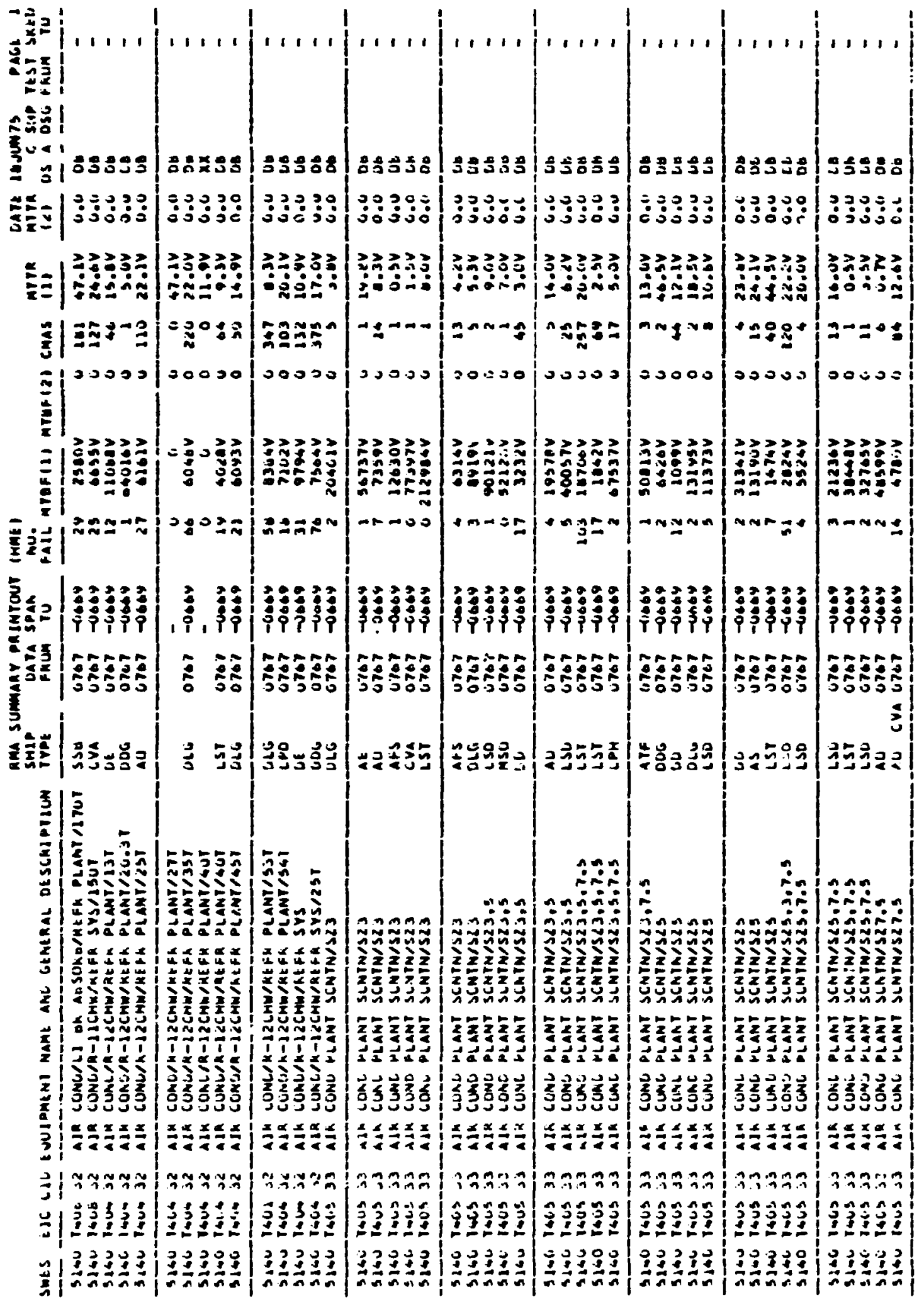




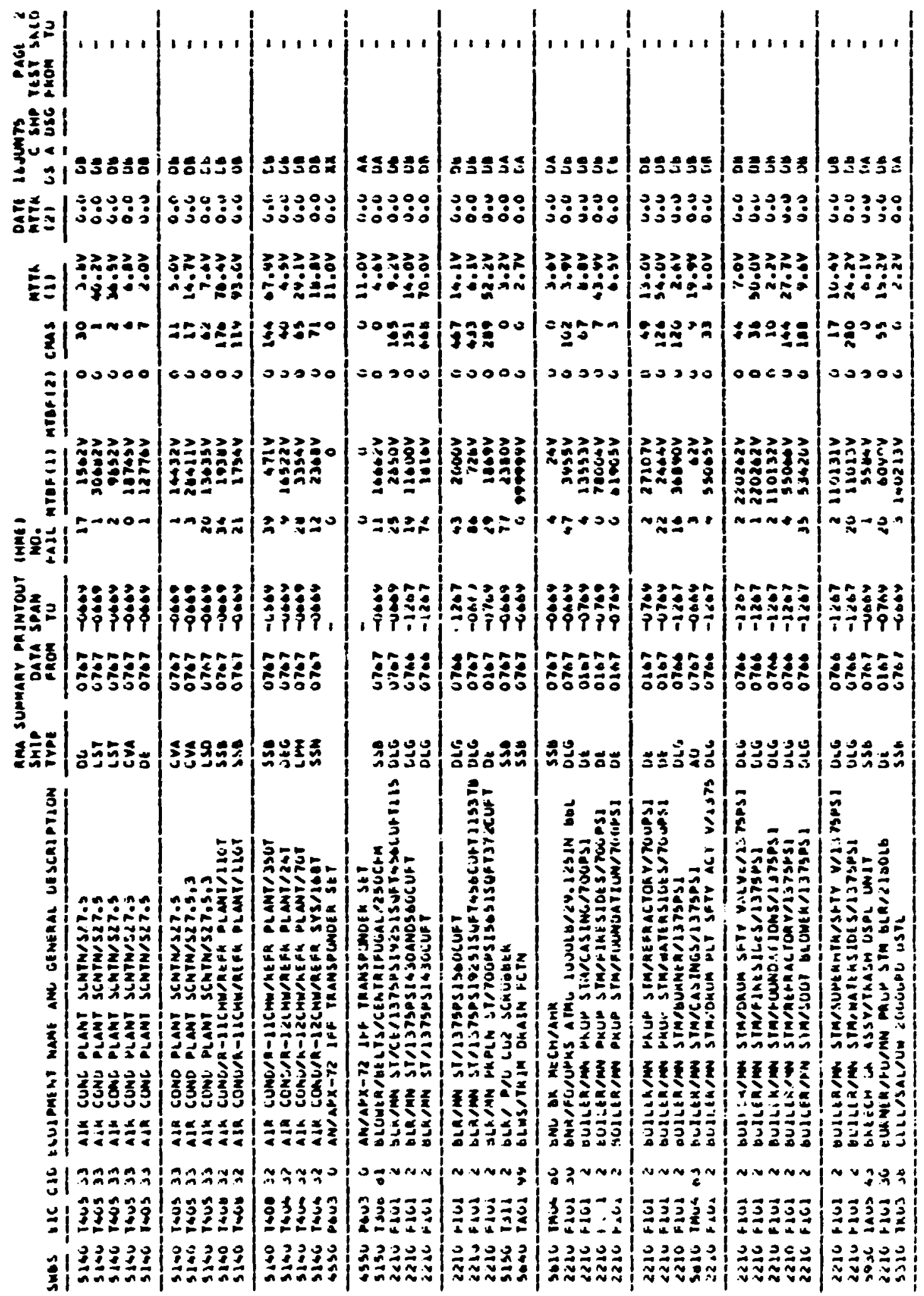




\begin{tabular}{|c|c|c|c|c|c|c|c|c|c|c|c|c|c|c|}
\hline Was & EIL LIL & I WAnE AMU GE? & 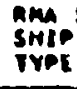 & & $\begin{array}{l}\text { ManY Pa } \\
\text { GAYA } \\
\text { FRum }\end{array}$ & $\begin{array}{l}\text { M INTCuT } \\
\text { SPAN } \\
\text { ro }\end{array}$ & 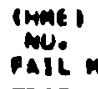 & nTEe 111 & MTSF 121 & cons & Mili & $\begin{array}{l}\text { DATE } \\
\text { MTPM } \\
\text { I } 21\end{array}$ & $\begin{array}{l}\text { ISNUNS } \\
\text { C SMP } \\
\text { us A OSG }\end{array}$ & $\begin{array}{l}\text { PAGt } \\
\text { TEST SKe } \\
\text { Fkum To }\end{array}$ \\
\hline $\begin{array}{l}\sin 310 \\
\sin 6 \\
232: 1 \\
3336 \\
3160 \\
\end{array}$ & 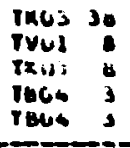 & 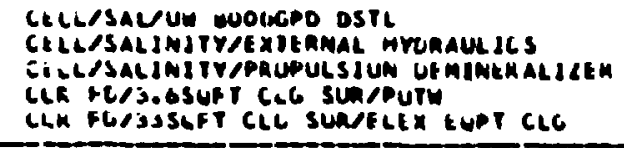 & 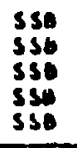 & & $\begin{array}{l}6767 \\
0767 \\
6767 \\
0767 \\
0767\end{array}$ & $\begin{array}{l}-0609 \\
-0669 \\
-0664 \\
-0664 \\
-1660\end{array}$ & $\begin{array}{c}3 \\
6 \\
1 \\
1\end{array}$ & $\begin{array}{r}200427 v \\
47200 v \\
672031 \\
2000004 \\
1462064\end{array}$ & $\begin{array}{l}0 \\
0 \\
0 \\
0 \\
0\end{array}$ & $\begin{array}{l}11 \\
0 \\
0 \\
0 \\
0\end{array}$ & $\begin{array}{l}0.7 v \\
0.3 v \\
0.3 v \\
2.7 v \\
1.0 v\end{array}$ & $\begin{array}{l}0.0 \\
0.6 \\
0.0 \\
0.0 \\
0.0\end{array}$ & $\begin{array}{l}\operatorname{UaA}_{\text {UA }} \\
\text { UAA } \\
\text { UA } \\
\text { CA }\end{array}$ & $\begin{array}{l}\bar{z} \\
\bar{z}\end{array}$ \\
\hline $\begin{array}{l}7200 \\
\text { sisu } \\
\text { sisc } \\
\text { sisc } \\
\text { s } 720 \\
\end{array}$ & 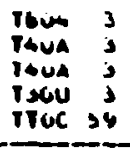 & 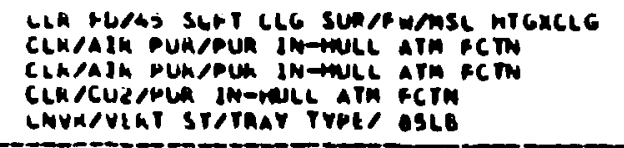 & $\begin{array}{l}\text { 5so } \\
\text { 536 } \\
\text { 5s8 } \\
\text { LPD }\end{array}$ & & $\begin{array}{l}0707 \\
0707 \\
0707 \\
0767\end{array}$ & $\begin{array}{l}-0600 \\
=-0604 \\
=0669 \\
=0669\end{array}$ & $\begin{array}{r}1 \\
1 \\
4 \\
4 \\
3 \\
7 \\
\end{array}$ & $\begin{array}{r}140206 \mathrm{~V} \\
0 \\
1020 \mathrm{~V} \\
1092 \mathrm{y} \\
076 \mathrm{y}\end{array}$ & $\begin{array}{l}a \\
6 \\
6 \\
0 \\
0\end{array}$ & $\begin{array}{c}0 \\
0 \\
u \\
0 \\
13\end{array}$ & $\begin{array}{l}2.04 \\
0.64 \\
0.04 \\
21.84 \\
21.64\end{array}$ & $\begin{array}{l}0.0 \\
0.0 \\
0.0 \\
0.0 \\
0.0 \\
0\end{array}$ & 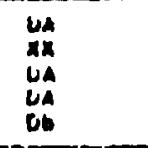 & $\begin{array}{l}\overline{-} \\
\overline{ } \\
=\end{array}$ \\
\hline $\begin{array}{l}3720 \\
3720 \\
37<0 \\
5120 \\
3720\end{array}$ & 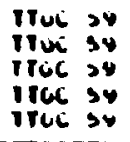 & 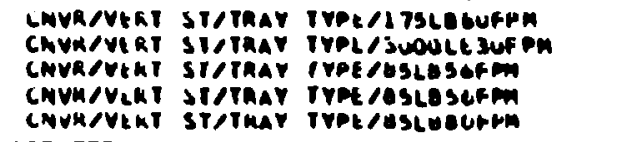 & $\begin{array}{l}\text { Ars } \\
\text { Ars } \\
\text { Dit } \\
\text { At } \\
\text { ars }\end{array}$ & DEG & $\begin{array}{l}0767 \\
0767 \\
0767 \\
0767 \\
0767\end{array}$ & $\begin{array}{l}-0609 \\
-0609 \\
-00044 \\
-6609 \\
-0.069\end{array}$ & $\begin{array}{r}31 \\
104 \\
10 \\
204\end{array}$ & 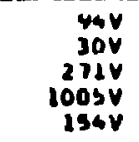 & $\begin{array}{l}0 \\
0 \\
0 \\
0 \\
0\end{array}$ & $\begin{array}{r}79 \\
127 \\
32 \\
15 \\
294\end{array}$ & 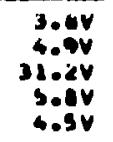 & $\begin{array}{l}0.6 \\
0.0 \\
0.0 \\
0.0 \\
0.0\end{array}$ & $\begin{array}{l}\text { Do } \\
\text { Os } \\
\text { ib } \\
\text { Git } \\
\text { Ct }\end{array}$ & $\begin{array}{l}\bar{z} \\
\bar{z}\end{array}$ \\
\hline $\begin{array}{l}\operatorname{sisc} \\
\text { sisu } \\
\text { sisio } \\
\text { sidic } \\
\text { sise }\end{array}$ & 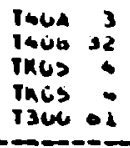 & 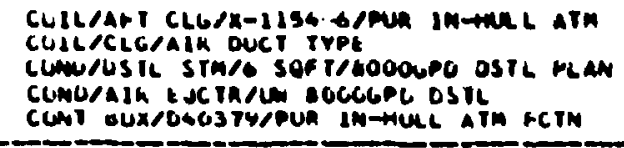 & $\begin{array}{l}358 \\
336 \\
\text { s58 } \\
\text { 5s8 } \\
350\end{array}$ & & $\begin{array}{l}0767 \\
6767 \\
0707 \\
6767 \\
0767 \\
\end{array}$ & 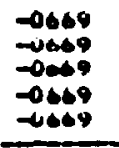 & $\begin{array}{l}1 \\
24 \\
13 \\
4\end{array}$ & 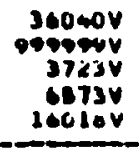 & $\begin{array}{l}0 \\
i \\
0 \\
0 \\
0 \\
0\end{array}$ & $\begin{array}{l}1 \\
0 \\
0 \\
0 \\
0\end{array}$ & $\begin{array}{l}3.54 \\
3.4 y \\
4.35 \\
2.34 \\
4.25 \\
\end{array}$ & $\begin{array}{l}0.11 \\
0.0 \\
0.0 \\
0.4 \\
0.4 \\
\end{array}$ & $\begin{array}{l}\text { OA } \\
\text { UA } \\
\text { OA } \\
\text { OA } \\
\text { CA } \\
\end{array}$ & 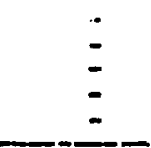 \\
\hline 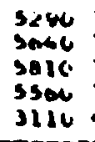 & 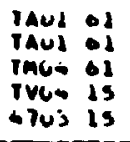 & 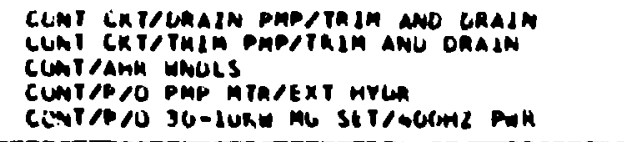 & $\begin{array}{l}\text { Ss6 } \\
\text { 5s6 } \\
\text { 5so } \\
\text { ssi } \\
\text { S58 }\end{array}$ & & $\begin{array}{l}0767 \\
0767 \\
6107 \\
0707 \\
6767\end{array}$ & 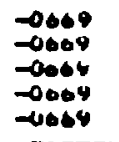 & $\begin{array}{r}14 \\
26 \\
23 i \\
40 \\
1\end{array}$ & $\begin{array}{r}770 y \\
1322004 \\
130607 y \\
706 y \\
108 c a v\end{array}$ & $\begin{array}{l}0 \\
0 \\
0 \\
\vdots \\
0\end{array}$ & $\begin{array}{l}0 \\
0 \\
0 \\
0 \\
0\end{array}$ & $\begin{array}{l}3.6 v \\
2.04 \\
2.0 v \\
7.0 v \\
10.0 v\end{array}$ & $\begin{array}{l}0.0 \\
0.0 \\
0.0 \\
0.01 \\
0.0\end{array}$ & $\begin{array}{l}\text { OA } \\
\text { CA } \\
\text { LA } \\
\text { CA } \\
\text { CA }\end{array}$ & $\begin{array}{l}\bar{z} \\
\bar{z}\end{array}$ \\
\hline $\begin{array}{l}\text { s110 } \\
\text { silv } \\
\text { ssic } \\
\text { ssic. } \\
\text { ssic }\end{array}$ & $\begin{array}{l}\text { inj is } \\
\text { inj is } \\
\text { Ifol : } \\
\text { trol: } \\
\text { iful: }\end{array}$ & 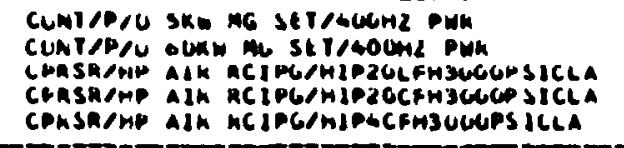 & $\begin{array}{l}\text { Ssb } \\
\text { ssb } \\
\text { Cva } \\
\text { CVh } \\
\text { at }\end{array}$ & $\begin{array}{l}\text { OL } \\
\text { Ong } \\
\text { aO }\end{array}$ & $\begin{array}{l}6767 \\
6767 \\
6707 \\
6767 \\
0767\end{array}$ & 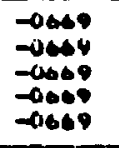 & $\begin{array}{r}0 \\
1 \\
240 \\
3\end{array}$ & $\begin{array}{l}260000 y \\
216000 y \\
216 y \\
116 y \\
403 y\end{array}$ & $\begin{array}{l}0 \\
\vdots \\
a \\
c \\
b\end{array}$ & $\begin{array}{r}0 \\
105 \\
117\end{array}$ & $\begin{array}{l}20.6 V \\
10.04 \\
0.7 v \\
17.44 \\
2.74\end{array}$ & $\begin{array}{l}0.0 \\
0.0 \\
0.0 \\
0.0 \\
0.0\end{array}$ & $\begin{array}{l}8 a \\
0 a \\
\text { Oa } \\
06 \\
06\end{array}$ & $\begin{array}{l}\overline{-} \\
\overline{-}\end{array}$ \\
\hline $\begin{array}{l}3>16 \\
3 \$ 10 \\
3 \$ 16 \\
3 \leq 16 \\
9160\end{array}$ & $\begin{array}{l}\text { Trui: } \\
\text { Irol: } \\
\text { Ircs: } \\
\text { Ircs: } \\
\text { Iswe : }\end{array}$ & 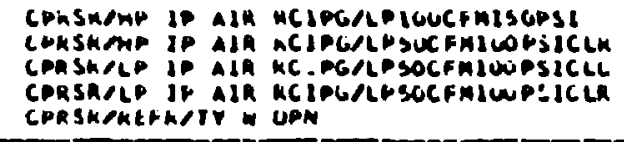 & $\begin{array}{l}\text { CO } \\
\text { CD } \\
\text { OC } \\
\text { iD } \\
\text { SSB }\end{array}$ & $\begin{array}{l}\text { UDG } \\
\text { ot } \\
\text { OCG } \\
\text { ODG }\end{array}$ & $\begin{array}{l}0747 \\
0767 \\
0767 \\
0767 \\
6767\end{array}$ & 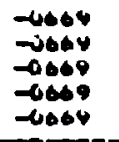 & $\begin{array}{r}52 \\
304 \\
204 \\
52\end{array}$ & 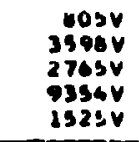 & $\begin{array}{l}0 \\
\dot{j} \\
\dot{0} \\
0 \\
0\end{array}$ & $\begin{array}{l}157 \\
161 \\
\operatorname{lng} \\
13 \\
0\end{array}$ & 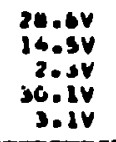 & $\begin{array}{l}0.0 \\
0.0 \\
0.0 \\
0.6 \\
0.0\end{array}$ & $\begin{array}{l}\text { co } \\
\text { of } \\
\text { ct } \\
\text { ch }\end{array}$ & $\begin{array}{l}\bar{z} \\
\bar{z}\end{array}$ \\
\hline $\begin{array}{l}5310 \\
5320 \\
5310 \\
3510 \\
5510\end{array}$ & 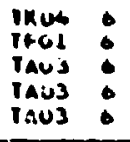 & 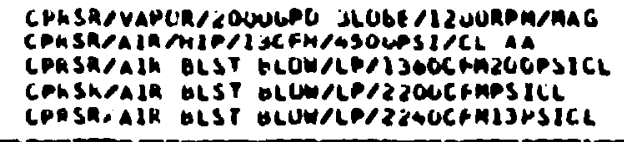 & $\begin{array}{l}\text { ss: } \\
\text { 3s5 } \\
\text { ipo } \\
\text { sst } \\
\text { sso }\end{array}$ & & $\begin{array}{l}0767 \\
0767 \\
0767 \\
0767 \\
6767\end{array}$ & 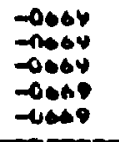 & $\begin{array}{r}36 \\
316 \\
2 \\
3 \\
1\end{array}$ & $\begin{array}{r}\text { bsov } \\
570 y \\
4250 y \\
70 y \\
\text { s3sv }\end{array}$ & $\begin{array}{l}0 \\
0 \\
6 \\
6 \\
c\end{array}$ & $\begin{array}{l}0 \\
0 \\
3 \\
3 \\
1\end{array}$ & $\begin{array}{l}23.0 V \\
0.3 y \\
y .3 v \\
1.4 y \\
0.3 y\end{array}$ & $\begin{array}{l}0.0 \\
0.0 \\
0.0 \\
0.0 \\
0.0\end{array}$ & 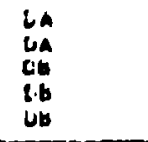 & $\begin{array}{l}\bar{z} \\
\bar{z}\end{array}$ \\
\hline $\begin{array}{l}3>10 \\
3210 \\
3>10 \\
3210 \\
3>10\end{array}$ & $\begin{array}{l}\text { Ifus : } \\
\text { IFul : } \\
\text { IFCl : } \\
\text { IFu: : } \\
\text { TFCi : }\end{array}$ & 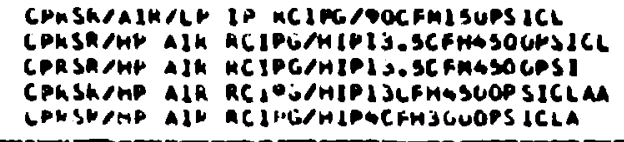 & $\begin{array}{l}\text { Ars } \\
\text { SSO } \\
\text { SSN } \\
\text { SSB } \\
\text { AL }\end{array}$ & & $\begin{array}{l}0767 \\
0707 \\
0707 \\
0707 \\
0707\end{array}$ & 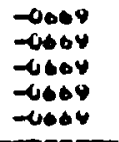 & $\begin{array}{r}123 \\
32 \\
232 \\
264\end{array}$ & $\begin{array}{l}2607 v \\
2035 \\
325 V \\
1260 \\
019 V\end{array}$ & $\begin{array}{l}0 \\
0 \\
0 \\
0 \\
0\end{array}$ & $\begin{array}{l}26 \\
227 \\
33 \\
361 \\
206\end{array}$ & 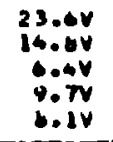 & $\begin{array}{l}0.6 \\
0.6 \\
0.6 \\
0.6 \\
0.0\end{array}$ & 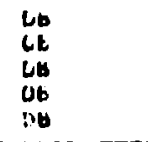 & $\begin{array}{l}\bar{z} \\
\overline{-}\end{array}$ \\
\hline
\end{tabular}




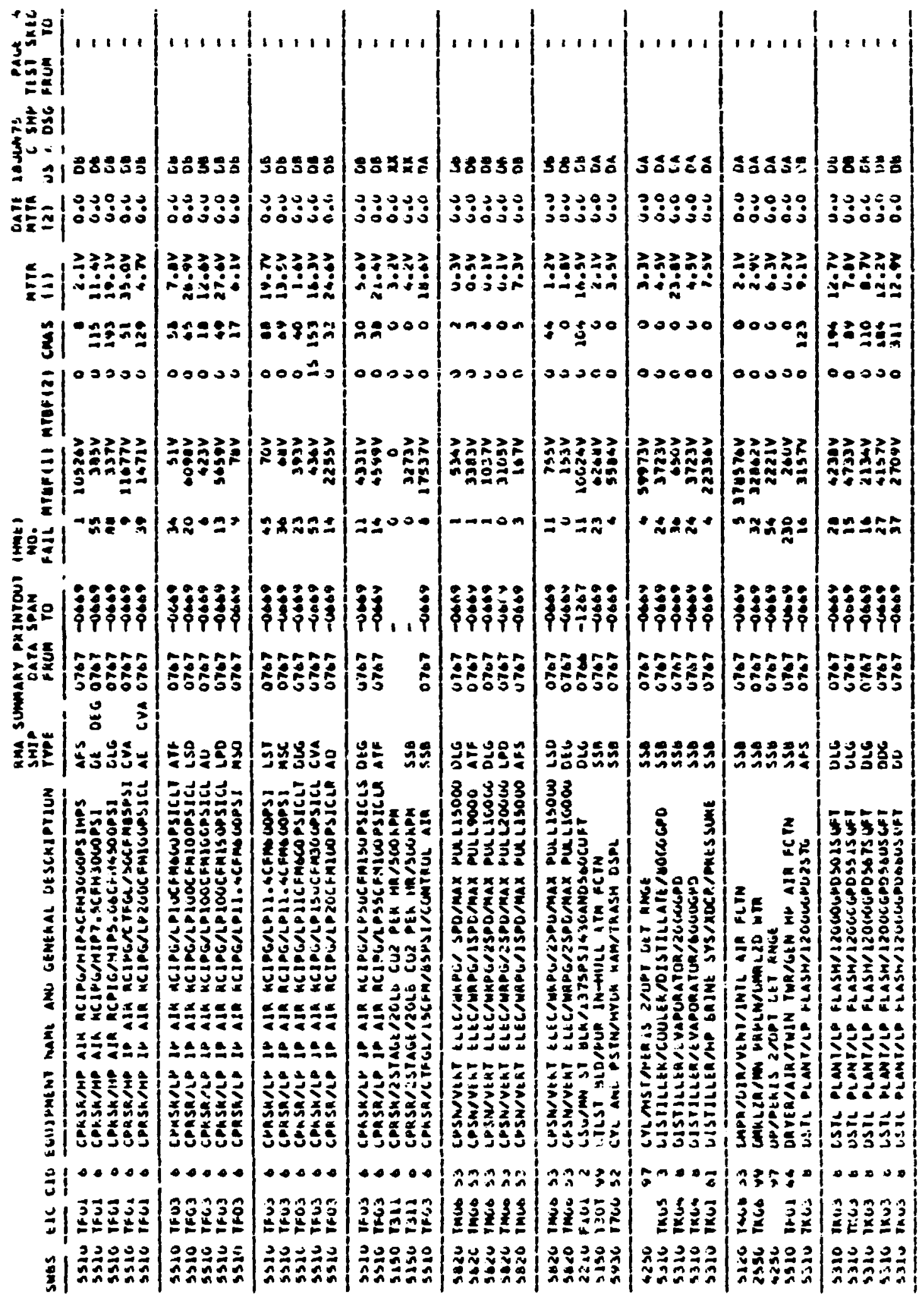




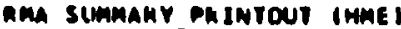

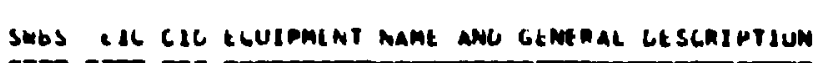

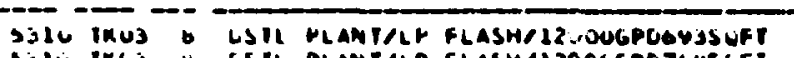

Sili IXCS \& CSIL PLANTLP FLASH/2200GGPOTOUS UF

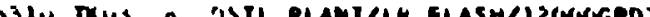

3316 TKGZ: CSIL PLANILL FLASHJ2UOOOGPLWU2SUFI

S310 IKUS USIL PLANTILF FLASH/3000GGPOSOUSUET LFO

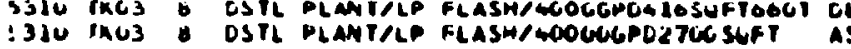

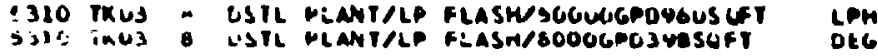

3310 IKO: O LSIL PLAN! SUEMG/20000CPDILLSUFI2ST UE

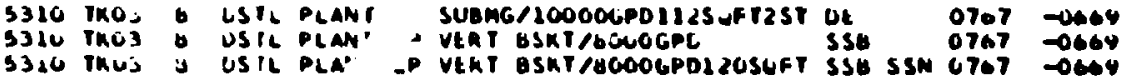

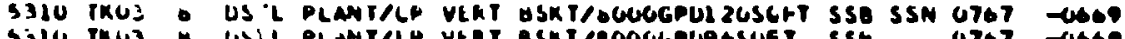

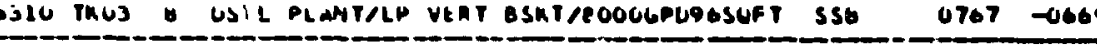

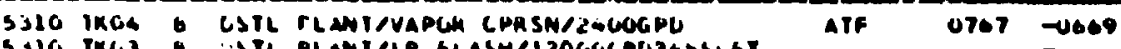

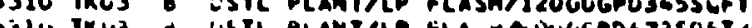

DEG o707 -

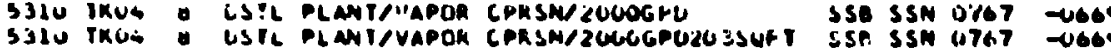

SlOC ISUS 12 LYHARAtC ANL HRT NU T464

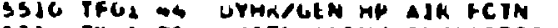

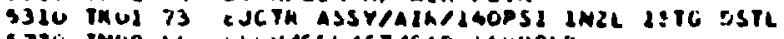

3730 TMU

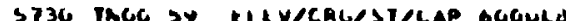

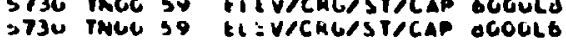

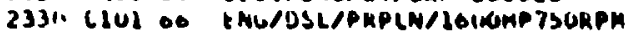

2330

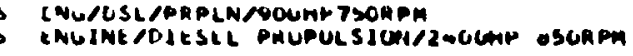

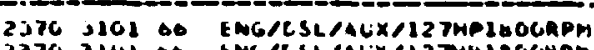

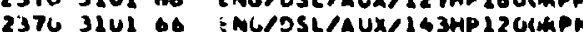

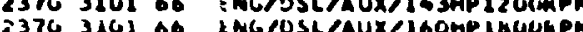

23/0 3lul ab ANG/SL/AUX/211MPQGURBA

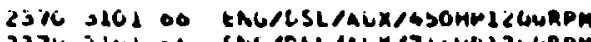

2374 3LUL O6 ENG/OSL/ALX/7LOMV121 GRPM

3116 316L Ob EMW/DSL/CEN UK/TIOHEJ2ULRPA

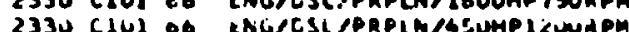

330 CIGL

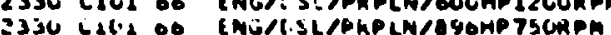

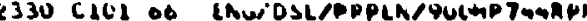

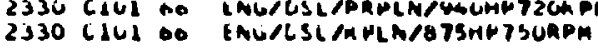

S58 $0767=0664$

$\begin{array}{lll}556 & 0767 & 6609 \\ 358 & 4767 & 0.064\end{array}$

$4767-0664$

$600 \quad 6767-6065$

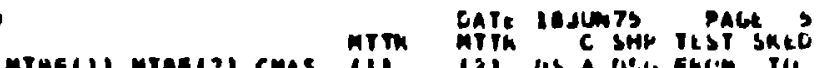

111

6.0 -

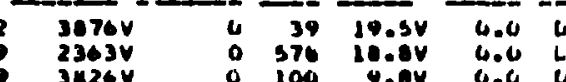

36264

10 3043V

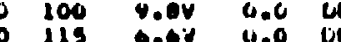

ils i.ti 13.0 lits

07070064
0707

ist 0767 -6064

S7lot

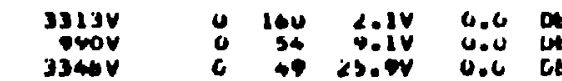

$3340 \mathrm{~V} c 40 \mathrm{cos} 0.0 \mathrm{cos}$

$1209 \mathrm{~V} 013216.2 \mathrm{~V}$ U.0 $\mathrm{CO}$

$23 \quad 1070 \mathrm{v}$

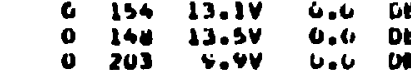

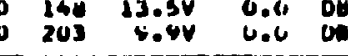

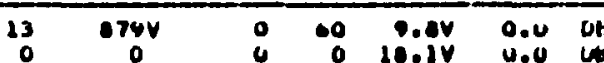

749245

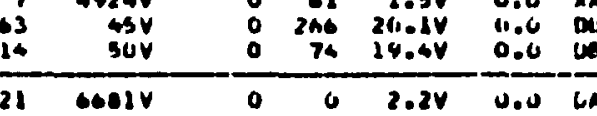

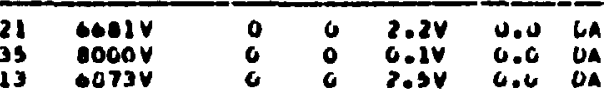

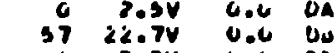

3

$70 \% 8$

34025

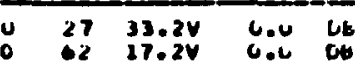

6.31 17.2v 6.06 ot

$2212.0 \mathrm{~V}$ 4.0 U1

\begin{tabular}{|c|c|c|c|c|c|c|c|}
\hline 3001 & -7723 & 0 & 0 & 0 & 7 & $4.0 \mathrm{~V}$ & 0.0 \\
\hline & & & & & & & \\
\hline $\begin{array}{l}0767 \\
6767 \\
0767\end{array}$ & $\begin{array}{l}-0064 \\
=0.09 \\
-0.649\end{array}$ & 31 & $\begin{array}{l}1030 \\
29140 \\
2510 y\end{array}$ & $a$ & $\begin{array}{r}222 \\
22 \\
25\end{array}$ & $\begin{array}{l}32.7 v \\
10.3 \mathrm{v} \\
17 . \mathrm{IV}\end{array}$ & $\begin{array}{l}0.6 \\
u .0 \\
6.0\end{array}$ \\
\hline
\end{tabular}

asi nsu 0767 -

aU 67.7 -0.04

$07 n 7-0004$
070

$\begin{array}{ccccc}166 & 0.7 & 0.0 & 0.0 \\ 6 & 24 & 3.7 & 0.0 & 0.0\end{array}$

\begin{tabular}{|c|c|c|c|c|c|c|c|c|c|c|}
\hline $\begin{array}{l}\text { LST } \\
\text { DEG } \\
D E G \\
\text { LST } \\
\text { MSC }\end{array}$ & $\begin{array}{l}0707 \\
6769 \\
\text { u767 } \\
0767 \\
0767\end{array}$ & $\begin{array}{l}-0604 \\
-0669 \\
-0664 \\
-0669 \\
-0664\end{array}$ & $\begin{array}{l}38 \\
i \\
4 j \\
22\end{array}$ & $\begin{array}{l}2717 v \\
5937 v \\
342724 \\
24374 \\
03464\end{array}$ & $\begin{array}{l}0 \\
0 \\
0 \\
0 \\
0\end{array}$ & $\begin{array}{r}415 \\
28 \\
106 \\
153\end{array}$ & $\begin{array}{l}10.7 v \\
20.0 V \\
30.0 V \\
13.24 \\
36.4 V\end{array}$ & $\begin{array}{l}0.0 \\
0.0 \\
1.01 \\
6.01 \\
0.01\end{array}$ & $\begin{array}{l}\text { Lo } \\
\text { c: } \\
0 \& \\
\text { U. } \\
\text { DB }\end{array}$ & $\begin{array}{l}= \\
=\end{array}$ \\
\hline $\begin{array}{l}\text { SSN } \\
\text { ATF } \\
\text { LST } \\
\text { SSH SS6 } \\
\text { ATt }\end{array}$ & $\begin{array}{l}0767 \\
6767 \\
6767 \\
0767 \\
0707\end{array}$ & $\begin{array}{l}-0064 \\
-0.69 \\
-0664 \\
-0064 \\
-0664\end{array}$ & $\begin{array}{r}4 \\
7 \\
17 \\
1 \\
29\end{array}$ & $\begin{array}{l}2030 V \\
3573 v \\
1334 v \\
7673 v \\
\text { SSG4V }\end{array}$ & $\begin{array}{l}0 \\
0 \\
0 \\
0 \\
0\end{array}$ & $\begin{array}{r}13 \\
13 \\
137\end{array}$ & $\begin{array}{r}8.3 V \\
4.05 \\
22.4 V \\
2.04 \\
13.14\end{array}$ & $\begin{array}{l}0.0 \\
0.0 \\
0.0 \\
0.0 \\
0.0\end{array}$ & $\begin{array}{l}\text { Du } \\
\text { WB } \\
\text { Do } \\
\text { oy } \\
\text { UB }\end{array}$ & $\begin{array}{l}= \\
=\end{array}$ \\
\hline
\end{tabular}




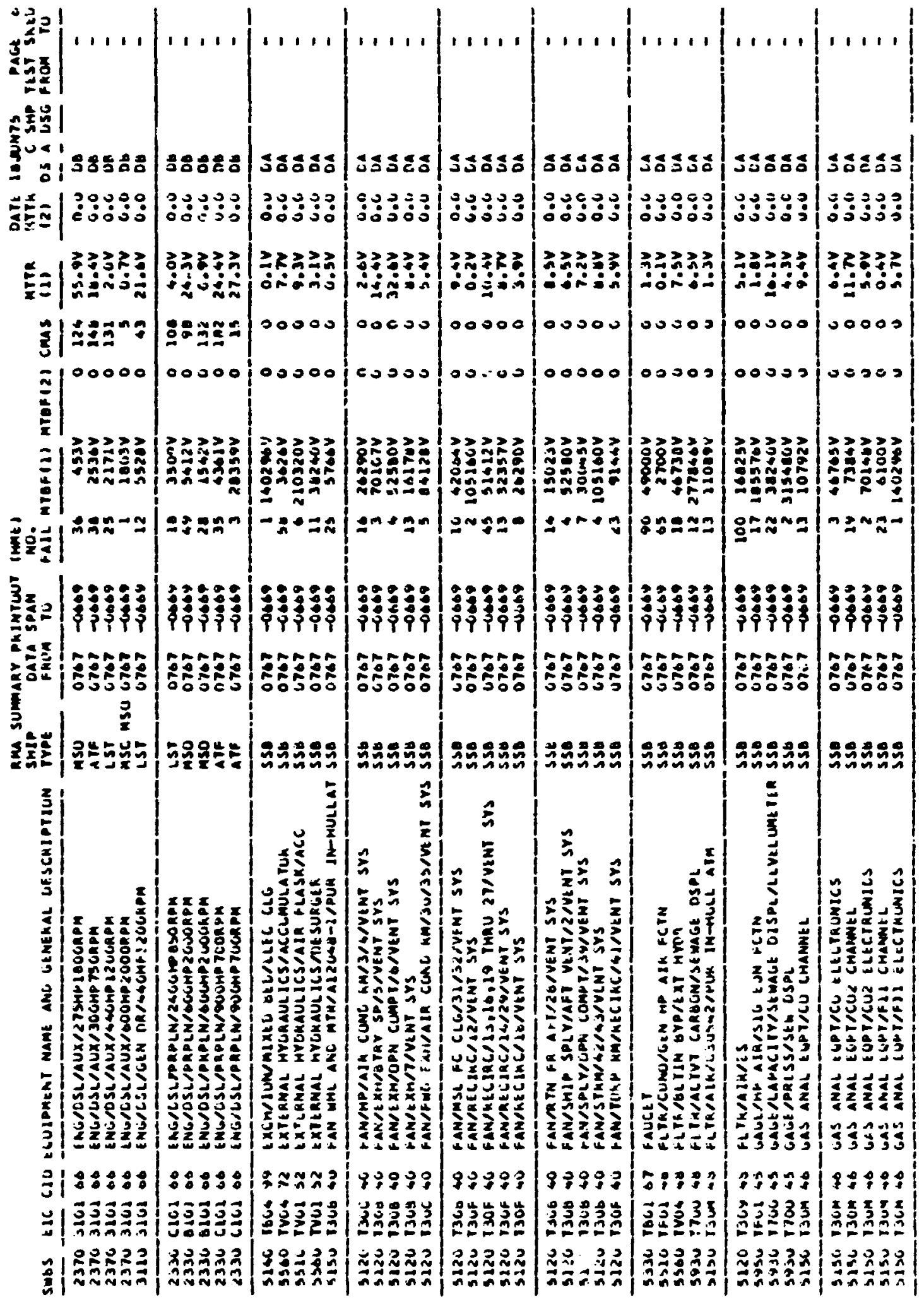


GMA SUMmaRY PK INTOUT InEt




MMA SUMMARY PRIMTOUT IWME

\begin{tabular}{|c|c|c|c|c|c|c|c|c|c|c|c|c|c|c|c|c|}
\hline & $2 \pi c c$ & C\&O & APMENY NAME ANL GENERAL OESCRSWTLON & 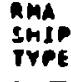 & & $\begin{array}{l}\text { ARY } \\
\text { OAPA } \\
\text { FROA }\end{array}$ & 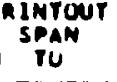 & $\begin{array}{l}\text { TWMEI } \\
\text { MOS. } \\
\text { FASL }\end{array}$ & mrafill & mraf(z) & cmas & $\begin{array}{l}\text { mirk } \\
\text { III }\end{array}$ & $\begin{array}{l}\text { Gatk } \\
\text { nirth } \\
\text { (2) }\end{array}$ & & $\begin{array}{l}\text { Ths } \\
\text { she } \\
\text { os }\end{array}$ & 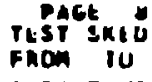 \\
\hline $\begin{array}{l}40 \\
i \neq 0 \\
140\end{array}$ & $\begin{array}{l}6705 \\
6703 \\
6703 \\
6703 \\
6705\end{array}$ & $\begin{array}{l}10 \\
18 \\
18 \\
10\end{array}$ & 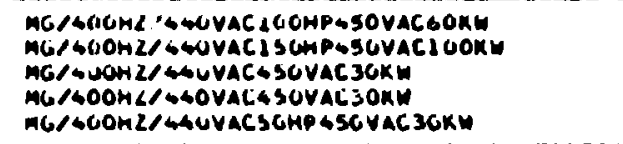 & $\begin{array}{l}006 \\
D 06 \\
D 0 \\
00 \\
006\end{array}$ & $\begin{array}{l}\text { LPO } \\
\text { DLG } \\
\text { DEG } \\
\text { DEG } \\
\text { DLG }\end{array}$ & $\begin{array}{l}0767 \\
6767 \\
0767 \\
0767 \\
6767\end{array}$ & $\begin{array}{l}-6069 \\
-0609 \\
-0669 \\
-0609 \\
-1069\end{array}$ & $\begin{array}{r}2 \\
3 \\
19 \\
54 \\
6\end{array}$ & 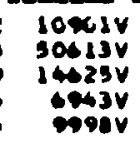 & $\begin{array}{l}0 \\
0 \\
0 \\
0 \\
0 \\
0\end{array}$ & $\begin{array}{l}\text { si } \\
\text { sul } \\
12\end{array}$ & $\begin{array}{l}2.1 \mathrm{~V} \\
2.0 \mathrm{~V} \\
2.0 \mathrm{OV} \\
26.2 \mathrm{~V} \\
77.0 \mathrm{~V}\end{array}$ & $\begin{array}{l}0.0 \\
0.0 \\
0.0 \\
0.0 \\
0.0\end{array}$ & $\begin{array}{l}0 . \\
60 \\
0 . \\
0.6\end{array}$ & & $\begin{array}{l}\bar{z} \\
\bar{z}\end{array}$ \\
\hline $\begin{array}{l}140 \\
140 \\
140 \\
140 \\
140\end{array}$ & $\begin{array}{l}+703 \\
-703 \\
-703 \\
6703 \\
6704\end{array}$ & $\begin{array}{l}16 \\
18 \\
18 \\
18 \\
18\end{array}$ & 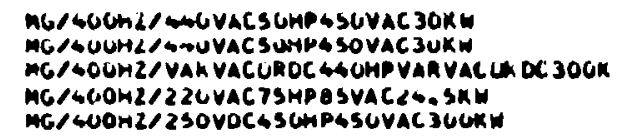 & $\begin{array}{l}\text { Dog } \\
006 \\
3 \$ 8 \\
\text { ot } \\
\text { 35. }\end{array}$ & $\begin{array}{l}\text { DLE } \\
\text { OLG } \\
\text { DEG }\end{array}$ & $\begin{array}{l}0767 \\
0767 \\
0707 \\
6767 \\
0767\end{array}$ & 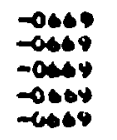 & $\begin{array}{r}32 \\
34 \\
0 \\
0 \\
0\end{array}$ & $\begin{array}{r}3462 y \\
3240 y \\
172673 v \\
161528 v \\
258719 y\end{array}$ & $\begin{array}{l}0 \\
\vdots \\
0 \\
0 \\
c\end{array}$ & $\begin{array}{r}91 \\
127 \\
0 \\
0 \\
1\end{array}$ & $\begin{array}{l}10.2 v \\
10.3 v \\
1.04 \\
1.0 .0 v \\
33.5 v\end{array}$ & $\begin{array}{l}0.0 \\
0.0 \\
0.0 \\
0.0 \\
0.0\end{array}$ & $\begin{array}{l}\text { Ds } \\
\text { o: } \\
\text { of } \\
\text { Lo } \\
\text { Un }\end{array}$ & & 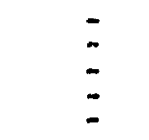 \\
\hline $\begin{array}{l}3140 \\
3140 \\
3146 \\
3140 \\
3140\end{array}$ & $\begin{array}{l}-704 \\
4704 \\
-704 \\
4704 \\
4705\end{array}$ & $\begin{array}{l}10 \\
10 \\
10 \\
10\end{array}$ & 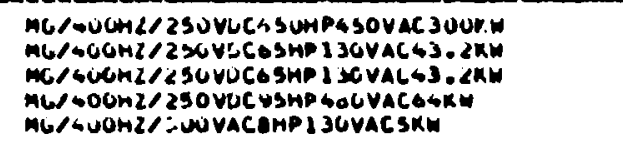 & $\begin{array}{l}\text { SSB } \\
\text { SSN } \\
\text { SSN } \\
\text { SSB } \\
\text { SSo }\end{array}$ & & $\begin{array}{l}0707 \\
6767 \\
0767 \\
4767 \\
0767\end{array}$ & $\begin{array}{l}-0069 \\
-0669 \\
-0669 \\
-0069 \\
-0069\end{array}$ & $\begin{array}{c}: \\
: \\
51 \\
25\end{array}$ & $\begin{array}{l}309044 y \\
46414 \\
32032 y \\
30 \% 6 y \\
15346 y\end{array}$ & $\begin{array}{l}0 \\
: \\
0 \\
0 \\
0\end{array}$ & $\begin{array}{r}23 \\
29 \\
293 \\
49\end{array}$ & $\begin{array}{l}53.54 \\
40.4 V \\
1.64 \\
15.64 \\
17.14\end{array}$ & $\begin{array}{l}0.6 \\
0.0 \\
0.0 \\
0.0 \\
0.0\end{array}$ & $\begin{array}{l}08 \\
06 \\
26 \\
06 \\
06\end{array}$ & & $\begin{array}{l}= \\
\vdots\end{array}$ \\
\hline $\begin{array}{l}3140 \\
3140 \\
2350 \\
2350 \\
2350\end{array}$ & 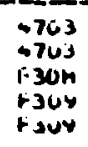 & $\begin{array}{l}16 \\
18 \\
17 \\
17 \\
17\end{array}$ & 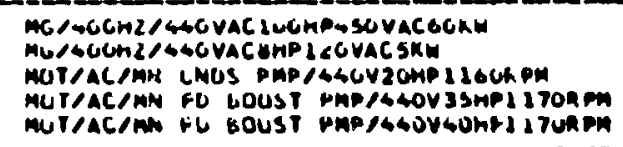 & $\begin{array}{l}\text { COG } \\
\text { SSN } \\
\text { DD } \\
\text { DD } \\
\text { DDG }\end{array}$ & $\begin{array}{l}\text { DDC } \\
\text { OOL } \\
\text { DLG }\end{array}$ & $\begin{array}{l}0767 \\
0707 \\
0767 \\
0767 \\
07 e 7\end{array}$ & $\begin{array}{l}-0069 \\
-0604 \\
0009 \\
0669 \\
-0669\end{array}$ & $\begin{array}{r}41 \\
2 \\
8 \\
25 \\
25\end{array}$ & $\begin{array}{l}4300 v \\
350004 \\
200004 \\
73324 \\
134596\end{array}$ & $\begin{array}{l}0 \\
0 \\
0 \\
0 \\
0\end{array}$ & 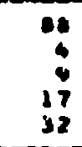 & $\begin{array}{l}53.5 V \\
16.1 V \\
20.2 \mathrm{~V} \\
50.1 \mathrm{~V} \\
60.5 \mathrm{~V}\end{array}$ & $\begin{array}{l}0.6 \\
0.0 \\
0.0 \\
0.0 \\
0.0\end{array}$ & 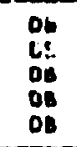 & & $\begin{array}{l}\bar{E} \\
=\end{array}$ \\
\hline $\begin{array}{l}2530 \\
3646 \\
3160 \\
2350 \\
2350\end{array}$ & 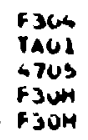 & $\begin{array}{l}17 \\
17 \\
17 \\
17 \\
17\end{array}$ & 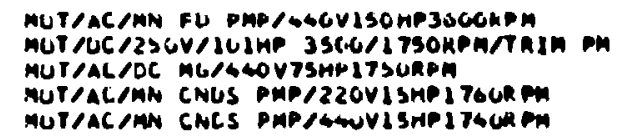 & $\begin{array}{l}556 \\
\text { 558 } \\
0 E \\
\text { LU } \\
\text { LSD }\end{array}$ & SSN & $\begin{array}{l}0747 \\
6767 \\
6767 \\
0767 \\
0747\end{array}$ & 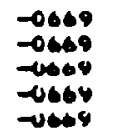 & $\begin{array}{r}7 \\
30 \\
15 \\
2 \\
7\end{array}$ & $\begin{array}{r}130212 \\
69002 y \\
637 V \\
93202 y \\
10652 V\end{array}$ & $\begin{array}{l}0 \\
0 \\
0 \\
0 \\
c\end{array}$ & $\begin{array}{c}13 \\
8 \\
11 \\
12 \\
11\end{array}$ & $\begin{array}{l}24.4 V \\
9.25 \\
25.3 v \\
11.4 y \\
9.14\end{array}$ & $\begin{array}{l}0.0 \\
0.0 \\
0.0 \\
0.0 \\
0.0\end{array}$ & $\begin{array}{l}\text { On } \\
\text { On }\end{array}$ & & $\begin{array}{l}\bar{z} \\
\bar{z}\end{array}$ \\
\hline $\begin{array}{l}2530 \\
2536 \\
2350 \\
2530 \\
2950\end{array}$ & 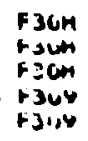 & $\begin{array}{l}17 \\
17 \\
17 \\
17\end{array}$ & 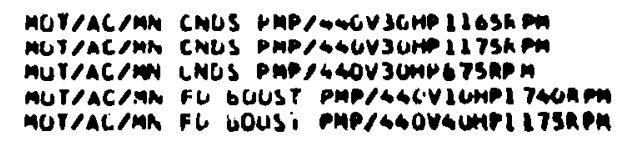 & $\begin{array}{l}\text { OLG } \\
\text { oL6 } \\
\text { iso } \\
\text { UL6 }\end{array}$ & & $\begin{array}{l}0767 \\
0767 \\
0767 \\
0767 \\
0767\end{array}$ & 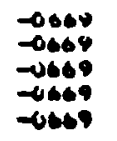 & $\begin{array}{l}1 \\
\vdots \\
11 \\
0\end{array}$ & $\begin{array}{r}0 \\
176057 v \\
93205 V \\
6972 V \\
362633 v\end{array}$ & $\begin{array}{l}0 \\
0 \\
0 \\
0 \\
0\end{array}$ & $\begin{array}{c}1 \\
1 \\
1 \\
16 \\
0\end{array}$ & 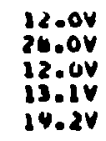 & $\begin{array}{l}0.6 \\
0.6 \\
6.6 \\
0.6 \\
0.6\end{array}$ & $\begin{array}{l}00 \\
16 \\
00\end{array}$ & & $\begin{array}{l}\vdots \\
\vdots\end{array}$ \\
\hline $\begin{array}{l}3240 \\
2330 \\
2350 \\
2380 \\
2300\end{array}$ & 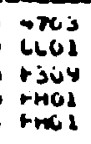 & $\begin{array}{l}17 \\
17 \\
17 \\
17\end{array}$ & 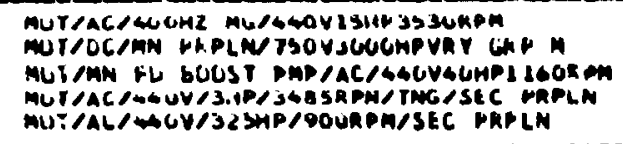 & $\begin{array}{l}\text { OE } \\
\text { ATF } \\
\text { QLG } \\
\text { SSQ } \\
\text { SS6 }\end{array}$ & & $\begin{array}{l}0767 \\
6767 \\
0767 \\
0767 \\
0767\end{array}$ & 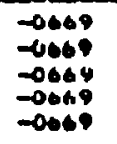 & $\begin{array}{l}6 \\
13 \\
1 \\
1\end{array}$ & $\begin{array}{l}75014 \\
63713 y \\
960 y \\
1166 y \\
353 y\end{array}$ & $\begin{array}{l}4 \\
0 \\
0 \\
0 \\
0\end{array}$ & $\begin{array}{r}13 \\
13 \\
0 \\
0\end{array}$ & 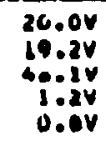 & $\begin{array}{l}0.0 \\
0.0 \\
0.0 \\
0.0 \\
0.0\end{array}$ & $\begin{array}{l}\text { Lu } \\
\text { CB } \\
\text { on } \\
\text { DA } \\
\text { La }\end{array}$ & & $\bar{\vdots}$ \\
\hline $\begin{array}{l}5200 \\
5310 \\
5320 \\
5350 \\
\text { siso }\end{array}$ & 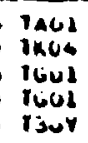 & $\begin{array}{l}17 \\
18 \\
17 \\
17 \\
17\end{array}$ & 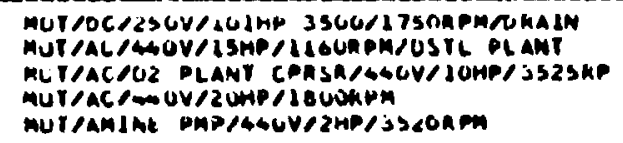 & $\begin{array}{l}350 \\
\text { 358 } \\
350 \\
358 \\
\text { 556 }\end{array}$ & & $\begin{array}{l}0767 \\
6767 \\
6767 \\
0767 \\
0767\end{array}$ & 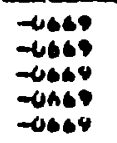 & $\begin{array}{r}7 \\
30 \\
60 \\
16\end{array}$ & $\begin{array}{r}15+12 \\
056 y \\
23303 v \\
700 y \\
130016\end{array}$ & $\begin{array}{l}1 \\
1 \\
0 \\
0 \\
0 \\
0\end{array}$ & $\begin{array}{l}0 \\
\vdots \\
: \\
0\end{array}$ & 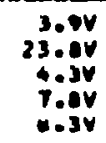 & $\begin{array}{l}6.0 \\
0.6 \\
0.6 \\
0.0 \\
0.0\end{array}$ & $\begin{array}{l}D_{A} \\
D_{A} \\
0, \\
\lim _{0 A}\end{array}$ & & $\begin{array}{l}\overline{ } \\
\overline{ }\end{array}$ \\
\hline $\begin{array}{l}5630 \\
3030 \\
2360 \\
6<30 \\
4<96\end{array}$ & 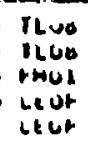 & $\begin{array}{l}16 \\
16 \\
43 \\
47 \\
47\end{array}$ & 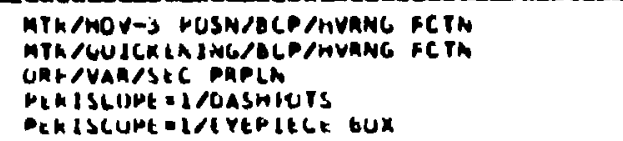 & $\begin{array}{l}556 \\
558 \\
5: 0 \\
5 \leq 6 \\
356\end{array}$ & & $\begin{array}{l}0767 \\
0747 \\
6767 \\
0707 \\
0707\end{array}$ & 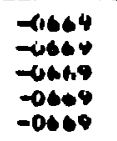 & $\begin{array}{l}3 \\
20 \\
20 \\
16\end{array}$ & $\begin{array}{l}1360 y \\
6700 y \\
67366 y \\
2607 y \\
7607 y\end{array}$ & $\begin{array}{l}u \\
u \\
0 \\
u \\
0\end{array}$ & $\begin{array}{l}0 \\
8 \\
0 \\
0 \\
0\end{array}$ & $\begin{array}{l}0.8 v \\
0.24 \\
3.14 \\
3.04 \\
0.04\end{array}$ & $\begin{array}{l}0.6 \\
0.6 \\
0.0 \\
6.0 \\
0.0\end{array}$ & $\begin{array}{l}\text { Da } \\
\text { DA } \\
\text { ina } \\
\text { oA } \\
\text { in }\end{array}$ & & $\begin{array}{l}\bar{z} \\
\bar{z}\end{array}$ \\
\hline
\end{tabular}




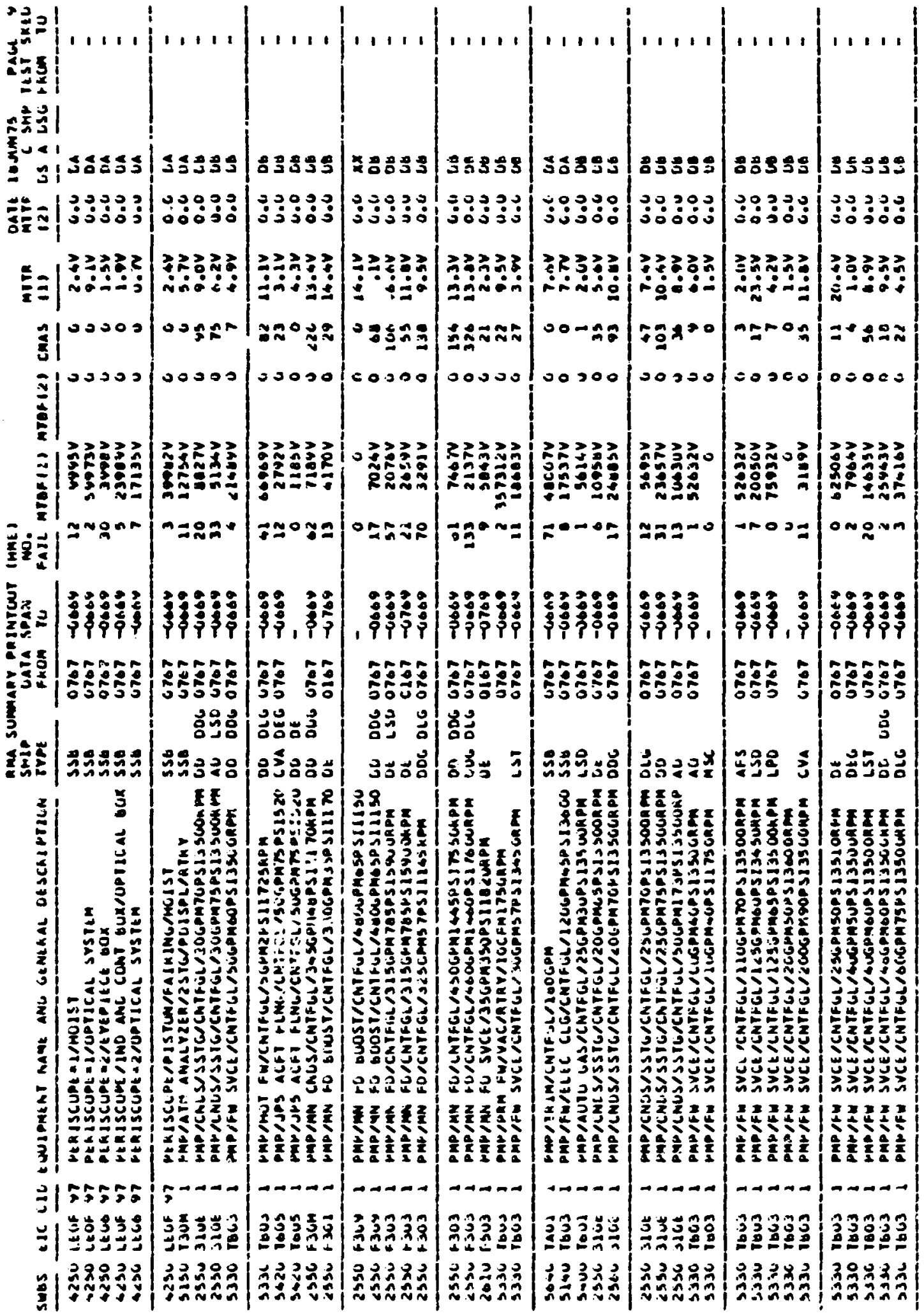




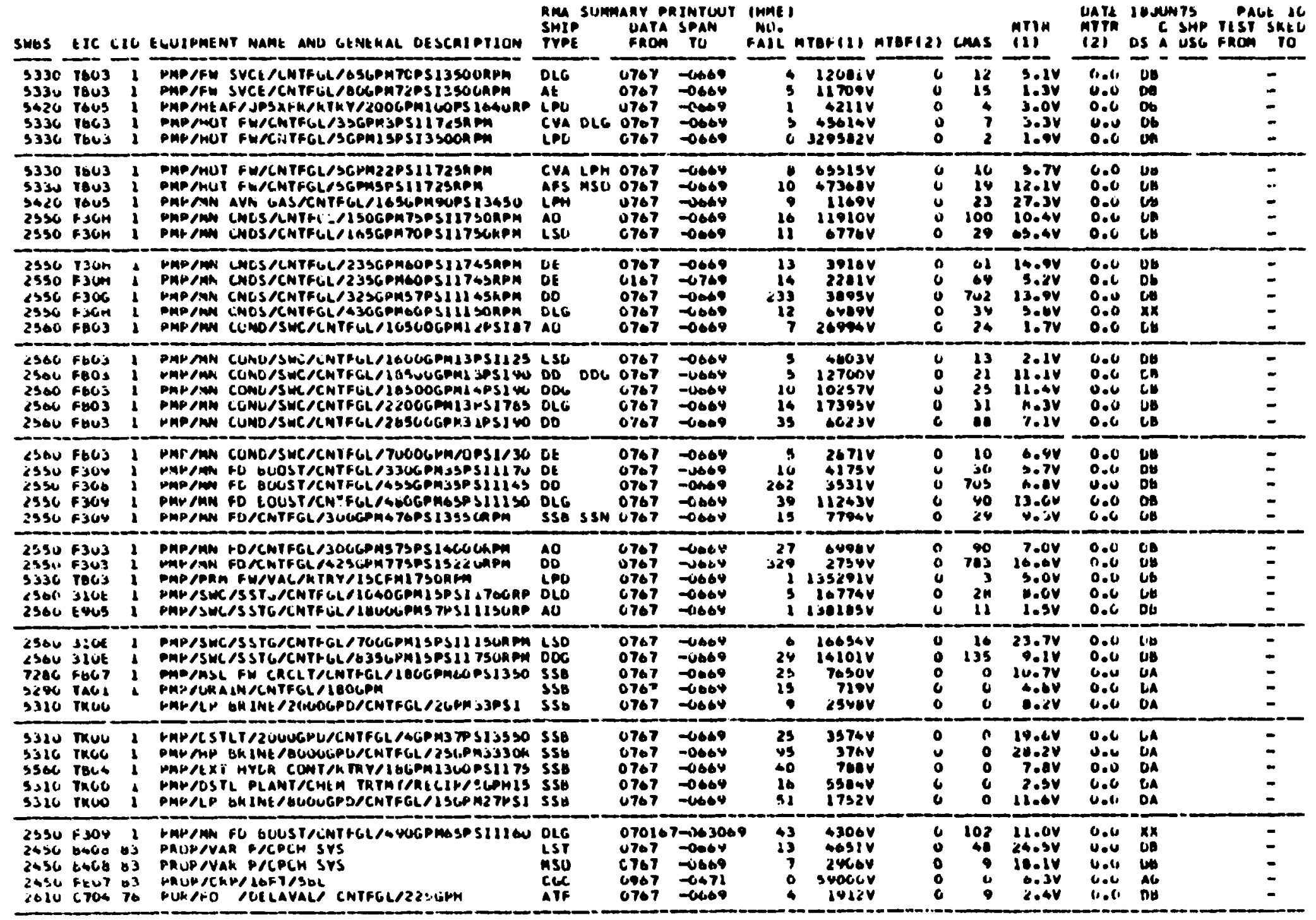




\begin{tabular}{|c|c|c|c|c|c|c|c|c|c|c|c|c|c|c|c|c|c|c|}
\hline \multirow{2}{*}{ 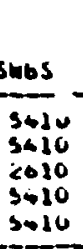 } & \multirow{2}{*}{$\begin{array}{l}610 \\
\text { Es } \\
6507 \\
6 \times 64 \\
6507 \\
6704\end{array}$} & \multirow{2}{*}{$\begin{array}{l}010 \\
76 \\
76 \\
76 \\
70\end{array}$} & \multirow{2}{*}{ 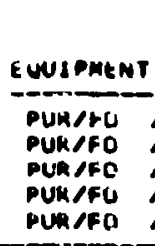 } & \multirow{2}{*}{ 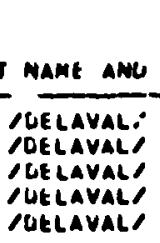 } & \multirow[t]{2}{*}{ GEMERAL UE SCAIPTION } & \multicolumn{4}{|c|}{ 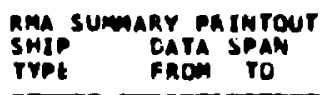 } & $\begin{array}{l}\text { Imoi } \\
\text { mali. }\end{array}$ & MTEF (1) & ATEF 121 & chas & \multirow{2}{*}{ 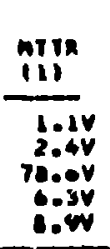 } & \multirow{2}{*}{ 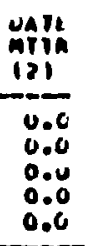 } & \multirow{2}{*}{ 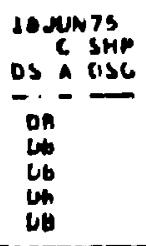 } & \multirow{2}{*}{\multicolumn{2}{|c|}{ 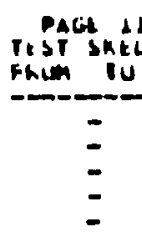 }} \\
\hline & & & & & & $\begin{array}{l}\text { OD } \\
\text { AO } \\
\text { MSC } \\
\text { LSD } \\
\text { LST }\end{array}$ & & $\begin{array}{l}0767 \\
0767 \\
0767 \\
6767 \\
0767\end{array}$ & $\begin{array}{l}-\infty \\
=0 \\
-\infty \\
-\infty\end{array}$ & $\begin{array}{c}2 \\
2 \\
11 \\
21\end{array}$ & $\begin{array}{l}170 y \\
2032 y \\
\text { osiov } \\
\text { abiv } \\
\text { 1400v }\end{array}$ & $\begin{array}{l}0 \\
0 \\
0 \\
0 \\
0\end{array}$ & $\begin{array}{l}4 \\
14 \\
40\end{array}$ & & & & & \\
\hline $\begin{array}{l}3+10 \\
3+10 \\
5+16 \\
30110 \\
26: 0\end{array}$ & $\begin{array}{l}\text { isu7 } \\
\text { rsut } \\
\text { f } 207 \\
\text { is } \\
\text { Fou }\end{array}$ & $\begin{array}{l}70 \\
70 \\
70 \\
70 \\
70\end{array}$ & $\begin{array}{l}\text { PUAFFO } \\
\text { PUK/FO } \\
\text { PUR/FU } \\
\text { pUK/FO } \\
\text { PUR/tO }\end{array}$ & 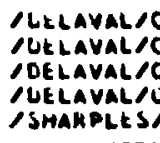 & 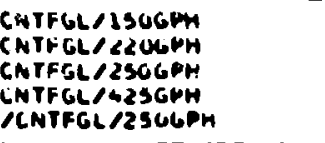 & $\begin{array}{l}\text { CVA } \\
\text { AO } \\
\text { UE } \\
\text { SSO }\end{array}$ & $\begin{array}{l}\text { LPH } \\
\text { LST } \\
\text { SSM }\end{array}$ & $\begin{array}{l}0767 \\
0767 \\
0767 \\
0767 \\
0767\end{array}$ & $\begin{array}{l}-0649 \\
0.0669 \\
0.069 \\
-0.69\end{array}$ & $\begin{array}{r}0 \\
10 \\
0 \\
3 \\
3\end{array}$ & $\begin{array}{l}\text { ousv } \\
721 y \\
1 \text { wy } \\
2003 y \\
\text { ogv }\end{array}$ & $\begin{array}{l}0 \\
0 \\
0 \\
0 \\
0\end{array}$ & $\begin{array}{r}2 \\
17 \\
17\end{array}$ & $\begin{array}{l}0.2 V \\
1.7 V \\
4.3 V \\
10.3 V \\
1.64\end{array}$ & $\begin{array}{l}0.0 \\
0.0 \\
0.0 \\
0.0 \\
0.0\end{array}$ & 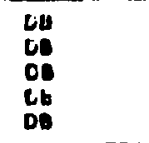 & & - \\
\hline $\begin{array}{l}3410 \\
2020 \\
2016 \\
2010 \\
5610\end{array}$ & 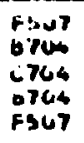 & $\begin{array}{l}70 \\
70 \\
76 \\
76 \\
76\end{array}$ & 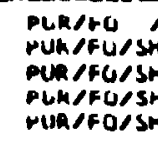 & 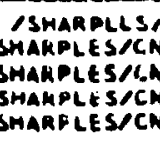 & $\begin{array}{l}\text { NTFGL/1SOGPH } \\
\text { WTFGL/2OOGPH } \\
\text { NTFGL/2SOGPH } \\
\text { NTFGL/2 TSGPPH }\end{array}$ & $\begin{array}{l}\text { AO } \\
\text { iss } \\
\text { Alp } \\
\text { MSO } \\
\text { DLG }\end{array}$ & & $\begin{array}{l}0767 \\
0767 \\
0767 \\
0767 \\
0767\end{array}$ & $\begin{array}{l}-0069 \\
0.069 \\
=6060 \\
=0669\end{array}$ & $\begin{array}{l}y \\
04 \\
10 \\
y\end{array}$ & $\begin{array}{l}1170 y \\
0428 \\
2145 y \\
1710 y \\
\text { sov }\end{array}$ & $\begin{array}{l}0 \\
0 \\
4 \\
0 \\
0 \\
0\end{array}$ & $\begin{array}{l}23 \\
136 \\
46 \\
25 \\
14\end{array}$ & $\begin{array}{l}13.2 Y \\
13.5 V \\
2.54 \\
1.3 v \\
\text { g.ev }\end{array}$ & $\begin{array}{l}0.0 \\
0.0 \\
0.0 \\
0.0 \\
0.0\end{array}$ & 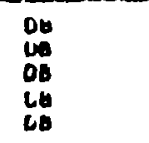 & & - \\
\hline $\begin{array}{l}2610 \\
2010 \\
3+20 \\
2020 \\
2620\end{array}$ & $\begin{array}{l}\text { Crum } \\
\text { urut } \\
\text { Tous } \\
\text { four } \\
\text { rour }\end{array}$ & $\begin{array}{l}16 \\
16 \\
76 \\
70 \\
70\end{array}$ & 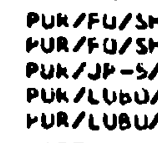 & 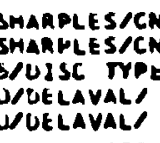 & $\begin{array}{l}\text { WTELL/27SGPH } \\
\text { NTFGL/ASOGPH } \\
\text { E/CNTFGL/20GGM } \\
\text { CWTFGL/225GPH } \\
\text { CNTFGL/22SGPH }\end{array}$ & $\begin{array}{l}\text { LST } \\
\text { CVA } \\
\text { of } \\
\text { CVA }\end{array}$ & cos & $\begin{array}{l}0767 \\
0767 \\
0767 \\
0767 \\
0767\end{array}$ & $-\infty$ & $\begin{array}{l}11 \\
21 \\
3 \\
15 \\
24\end{array}$ & $\begin{array}{l}2504 y \\
1704 y \\
1254 y \\
2007 v \\
2307 v\end{array}$ & $\begin{array}{l}0 \\
0 \\
0 \\
0 \\
0\end{array}$ & $\begin{array}{l}55 \\
63 \\
5 \\
30 \\
30\end{array}$ & $\begin{array}{l}0.3 V \\
39.0 .4 V \\
1.05 V \\
14.0 V \\
17.07 v\end{array}$ & $\begin{array}{l}0.0 \\
0.0 \\
0.0 \\
0.0 \\
0.0\end{array}$ & $\begin{array}{l}\text { Lu } \\
\text { Do } \\
\text { ve } \\
\text { Lut } \\
\text { D. }\end{array}$ & & - \\
\hline $\begin{array}{l}2020 \\
2020 \\
2610 \\
2 n 24 \\
2020\end{array}$ & 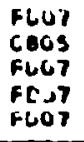 & $\begin{array}{l}16 \\
16 \\
76 \\
76 \\
76\end{array}$ & 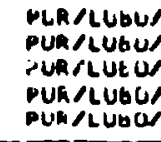 & 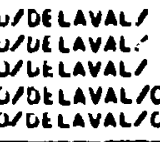 & $\begin{array}{l}\text { CNTFGL/225GGH } \\
\text { CNIFGL/225LLHH } \\
\text { CNTEGL/3SOGPH } \\
\text { CNTHGL/LSOGPH }\end{array}$ & $\begin{array}{l}\text { Arf } \\
\text { ise } \\
\text { Al } \\
\text { CVA }\end{array}$ & 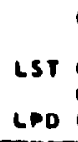 & $\begin{array}{l}0767 \\
0767 \\
6767 \\
0767\end{array}$ & $\begin{array}{l}=0609 \\
=-0069 \\
=0604\end{array}$ & $\begin{array}{c}1 \\
0 \\
16 \\
1 \\
14\end{array}$ & $\begin{array}{c}0 \\
0 \\
2061 v \\
15027 v \\
\text { incov }\end{array}$ & $\ddot{0}$ & $\begin{array}{r}32 \\
0 \\
76 \\
3 \\
05\end{array}$ & $\begin{array}{l}2.4 V \\
2.4 V \\
0.3 V \\
0.2 V \\
0.6 V\end{array}$ & $\begin{array}{l}0.0 \\
0.0 \\
0.0 \\
0.0 \\
0.6\end{array}$ & $\begin{array}{l}\text { Ub } \\
\text { Ub } \\
\text { Ut } \\
\text { in } \\
\text { Du }\end{array}$ & $\overline{-}$ & 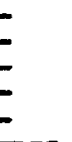 \\
\hline $\begin{array}{l}20<0 \\
2010 \\
2620 \\
2020 \\
2020\end{array}$ & 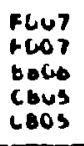 & $\begin{array}{l}76 \\
76 \\
76 \\
76 \\
76\end{array}$ & 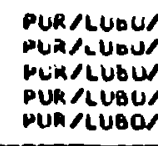 & $\begin{array}{l}\text { W/ELLAVAL/C } \\
\text { W/LELAVALKC } \\
\text { WSHAPLES/C } \\
\text { U/SHAKPLES } \\
\text { D/SWARPLLSS }\end{array}$ & GPM & $\begin{array}{l}\text { CVA } \\
\text { DE } \\
\text { LST } \\
\text { ATf } \\
\text { aTf }\end{array}$ & $\begin{array}{l}\text { DDG } \\
\text { LST }\end{array}$ & $\begin{array}{l}0767 \\
0767 \\
0767 \\
0767 \\
0767\end{array}$ & $\begin{array}{l}\rightarrow \infty \\
-\infty\end{array}$ & $\begin{array}{r}19 \\
11 \\
32 \\
8 \\
\end{array}$ & $\begin{array}{l}42 \\
17 \\
11 \\
50 \\
50\end{array}$ & $:$ & $\begin{array}{l}07 \\
32 \\
93 \\
41 \\
33\end{array}$ & $\begin{array}{r}12.0 v \\
s .0 v \\
12.0 v \\
4.2 v \\
2.22\end{array}$ & $\begin{array}{l}0.6 \\
0.0 \\
0.6 \\
0.6 \\
0.6\end{array}$ & 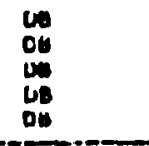 & & - \\
\hline $\begin{array}{l}2010 \\
2020 \\
2620 \\
2620 \\
2026\end{array}$ & $\begin{array}{l}\text { Fow } \\
\text { rec } \\
\text { fwo } \\
\text { row } \\
\text { roof }\end{array}$ & $\begin{array}{l}16 \\
76 \\
76 \\
76 \\
76\end{array}$ & 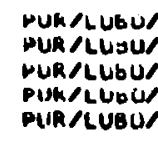 & $\begin{array}{l}\text { J/SHAKOLE } \\
\text { J/SHAR PLE } \\
\text { J/SHAKPLE } \\
\text { J/SWARPLE } \\
\text { J/SWARPLE }\end{array}$ & $\begin{array}{l}G P H \\
G P H \\
G P H \\
G P N \\
G P N\end{array}$ & $\begin{array}{l}\text { DE } \\
\text { OLG } \\
\text { DEG } \\
\text { 5SB } \\
\text { 10 }\end{array}$ & s & $\begin{array}{l}0747 \\
0767 \\
0767 \\
0767 \\
0767\end{array}$ & $\begin{array}{l}-0604 \\
-0609 \\
-0609 \\
-0604 \\
-0669\end{array}$ & $\begin{array}{r}120 \\
20 \\
24 \\
23 \\
37\end{array}$ & $\begin{array}{l}10420 \\
17194 \\
21158 \\
1417 v \\
13 s 0 v\end{array}$ & $\begin{array}{l}\vdots \\
\vdots \\
0 \\
0\end{array}$ & $\begin{array}{l}467 \\
53 \\
320 \\
61 \\
101\end{array}$ & $\begin{array}{r}0.0 v \\
22.2 v \\
3.0 v \\
3.4 v \\
13.5 v\end{array}$ & $\begin{array}{l}0.0 \\
0.0 \\
0.0 \\
0.0 \\
0.0\end{array}$ & $\begin{array}{l}\text { Du } \\
\text { cus } \\
\text { w. } \\
\text { Do }\end{array}$ & & \\
\hline $\begin{array}{l}2020 \\
5100 \\
3100 \\
3100 \\
3160\end{array}$ & $\begin{array}{l}6806 \\
1301 \\
i s 03 \\
i s 03 \\
1503\end{array}$ & $\begin{array}{l}76 \\
32 \\
32 \\
32 \\
32\end{array}$ & $\begin{array}{l}\text { PUR/LUSUA } \\
\text { REFR SYSA } \\
\text { REFR SYS } \\
\text { REFK SYS } \\
\text { REFA SYS }\end{array}$ & $\begin{array}{l}\text { U/SHARVLES } \\
S / K-21 \text { TU } \\
S / R-1201 R \\
S / K-1201 K \\
S / H-120 I R\end{array}$ & 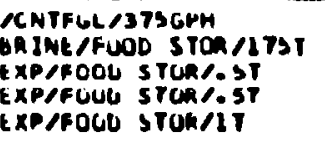 & $\begin{array}{l}\text { ist } \\
\text { Af } \\
\text { isso } \\
\text { isc } \\
\text { at }\end{array}$ & & $\begin{array}{l}0767 \\
0767\end{array}$ & זער & $\begin{array}{l}22 \\
18 \\
6 \\
11 \\
16\end{array}$ & $\begin{array}{l}2723 v \\
2323 v \\
\text { sogev } \\
4236 v \\
2770 v\end{array}$ & $\begin{array}{l}0 \\
0 \\
0 \\
0\end{array}$ & $\begin{array}{r}10 \\
132 \\
0 \\
36 \\
10\end{array}$ & $\begin{array}{l}0.0 V \\
02.0 V \\
11.04 \\
21.34 \\
\text { s.ov }\end{array}$ & $\begin{array}{l}0.0 \\
0.0 \\
0.0 \\
0.0 \\
0.0\end{array}$ & 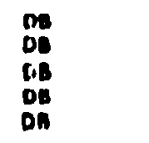 & & \\
\hline $\begin{array}{l}5160 \\
5160 \\
3160 \\
5160 \\
5160\end{array}$ & $\begin{array}{l}\text { isco } \\
\text { isis } \\
\text { isus } \\
\text { isus } \\
\text { Tsus }\end{array}$ & $\begin{array}{l}32 \\
32 \\
32 \\
32 \\
32\end{array}$ & 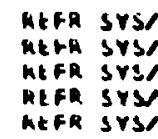 & 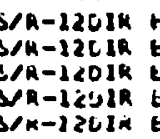 & 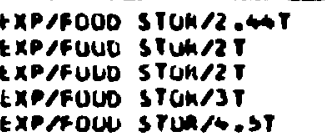 & $\begin{array}{l}\text { lST } \\
\text { ULG } \\
\text { ULG } \\
\text { LST } \\
\text { AO }\end{array}$ & & $\begin{array}{l}0767 \\
0767 \\
0767 \\
0767 \\
0767\end{array}$ & $\begin{array}{l}-\infty \\
\rightarrow \infty \\
=\infty \\
-\infty\end{array}$ & $\begin{array}{l}27 \\
56 \\
23 \\
24 \\
7\end{array}$ & $\begin{array}{l}2375 y \\
2093 y \\
\text { 1615y } \\
\text { invy } \\
\text { 46sov }\end{array}$ & $\begin{array}{l}0 \\
0 \\
0 \\
0 \\
0\end{array}$ & $\begin{array}{l}222 \\
276 \\
67 \\
99 \\
22\end{array}$ & 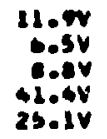 & $\begin{array}{l}0.0 \\
4.6 \\
0.0 \\
6.0 \\
0.0\end{array}$ & $\begin{array}{l}\text { Do } \\
\text { Do } \\
\text { Do } \\
\text { in }\end{array}$ & $\overline{-}$ & 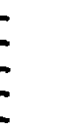 \\
\hline
\end{tabular}


ama SUMMAHY PRINTOUT IOME

SWES EIL CLC EGUIDMENT MAME ANG GENLRAL DESCRIPTJGM 5200 TSU3 22 KLFK SYS/A-1201K ExP/FOUC STUKAT

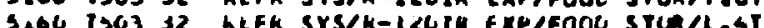

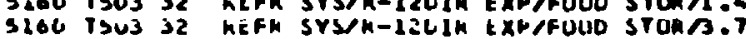

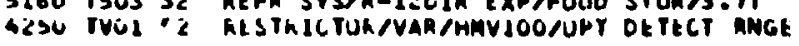

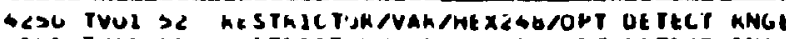

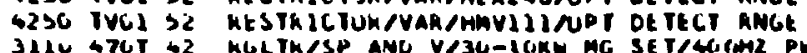

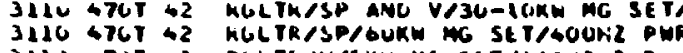

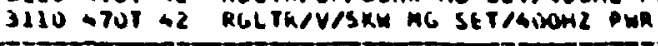

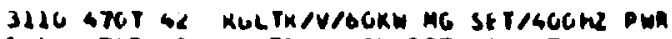
S\$lG 4767 42 RULTh/UKAIN/OSTL PLANT 3310 1KO4 10 huTAMTR

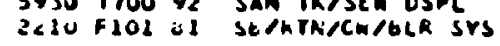

$230 C$ TVLA SQ SICCNLAKY PKOPLLS IONAHOIST MECHAPISM 23bl FHUS Q: SLCONEAKY PKUPULS IUN/SOL/MOTUR HUIST

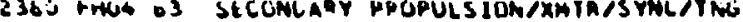
ssiu TFul to StPIMSTME

GTMAIMER/YOUISTILLEU WATIK

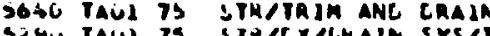

列

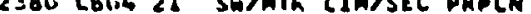

SSlo TUOA al SW/PRESS/EVAP ST SPLY/OW FCTM

T260 THG YL TAAKAFE/STO CAP JUGALAMSL HTGXCLG

\$36C TVROA VZ TKNUENT AMO SPLY/LXT HYLR

SE 10 TKOI Y2 TK/HR INE/AR ORINE SYS/OW FCN

syju laus is Thash CAN RTMR bour

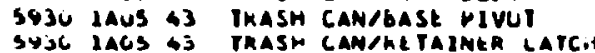

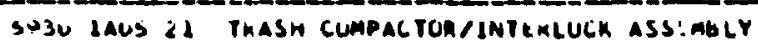

G

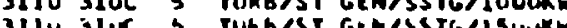

3110 3loL 5 TUkiss! GEM/SSTG

3210 jlWC 5 TLKA/SI UEN/SSTG/3OOKM

3210 BILC 3 IUKG/SI GEN/SSTG/4OLKM

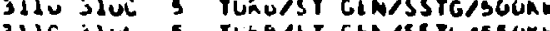

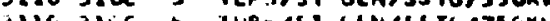

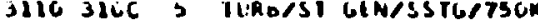

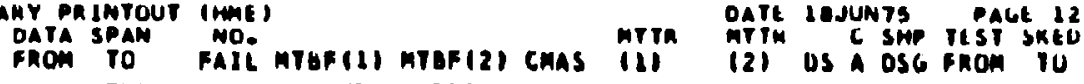

\begin{tabular}{|c|c|c|c|c|c|c|c|c|c|c|c|}
\hline $\begin{array}{l}\text { Do } \\
\text { AO } \\
\text { SS6 } \\
\text { DLG } \\
\text { SSB }\end{array}$ & 006 & $\begin{array}{l}0767 \\
6767 \\
0767 \\
6767 \\
0767\end{array}$ & $\begin{array}{l}-0609 \\
-0669 \\
-6669 \\
-6664 \\
-6664\end{array}$ & $\begin{array}{l}27 \\
16 \\
16 \\
23\end{array}$ & $\begin{array}{l}10004 \\
20304 \\
39704 \\
6374 y \\
52134\end{array}$ & $\begin{array}{l}u \\
u \\
a \\
u \\
0\end{array}$ & $\begin{array}{r}04 \\
50 \\
145 \\
45 \\
6\end{array}$ & $\begin{array}{r}13.4 V \\
4.4 V \\
9.44 \\
10.3 V \\
1.2 V\end{array}$ & $\begin{array}{l}0.0 \\
0.0 \\
0.0 \\
0.0 \\
0.0\end{array}$ & $\begin{array}{l}\text { wo } \\
n B \\
60 \\
00 \\
\text { on }\end{array}$ & $\bar{E}$ \\
\hline $\begin{array}{l}\text { 5s8 } \\
\text { 530 } \\
\text { 536 } \\
\text { 538 } \\
\text { 356 }\end{array}$ & & $\begin{array}{l}0767 \\
0767 \\
0767 \\
6767 \\
6767\end{array}$ & $\begin{array}{l}-0069 \\
-0664 \\
=0664 \\
=0664 \\
-0609\end{array}$ & $\begin{array}{l}2 \\
3 \\
11 \\
5 \\
30\end{array}$ & 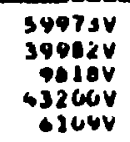 & $\begin{array}{l}0 \\
0 \\
0 \\
0 \\
0\end{array}$ & $\begin{array}{l}0 \\
0 \\
0 \\
0 \\
0\end{array}$ & $\begin{array}{l}0.3 v \\
0.0 v \\
6.0 v \\
7.2 v \\
4.0 .0 v\end{array}$ & $\begin{array}{l}0.0 \\
0.0 \\
6.0 \\
6.0 \\
0.0\end{array}$ & $\begin{array}{l}\text { on } \\
\text { oA } \\
\text { la } \\
\text { on } \\
\text { ca }\end{array}$ & - \\
\hline $\begin{array}{l}550 \\
550 \\
558 \\
556 \\
\text { S56 }\end{array}$ & & $\begin{array}{l}6767 \\
6767 \\
6767 \\
6767 \\
6767\end{array}$ & $\begin{array}{l}-6064 \\
-0664 \\
-6664 \\
-0669 \\
-0604\end{array}$ & $\begin{array}{c}8 \\
6 \\
14 \\
12\end{array}$ & $\begin{array}{r}27000 \mathrm{~V} \\
16091 \mathrm{~V} \\
37576 \mathrm{~V} \\
00091 \mathrm{~V} \\
902 \mathrm{LV}\end{array}$ & $\begin{array}{l}0 \\
0 \\
0 \\
0 \\
0\end{array}$ & $\begin{array}{r}0 \\
0 \\
0 \\
0 \\
1<2\end{array}$ & $\begin{array}{l}12.3 V \\
6.3 V \\
2.35 \\
14.18 \\
8.04\end{array}$ & $\begin{array}{l}0.0 \\
6.00 \\
0.0 \\
0.0 \\
0.0\end{array}$ & $\begin{array}{l}G_{A A} \\
D A \\
O A \\
\text { UA } \\
\text { GS }\end{array}$ & I \\
\hline $\begin{array}{l}\text { 5s6 } \\
\text { 538 } \\
\text { 538 } \\
\text { 5s0 } \\
\text { 5so }\end{array}$ & & $\begin{array}{l}0767 \\
0767 \\
0767 \\
0767 \\
0767\end{array}$ & $\begin{array}{l}-6069 \\
-0664 \\
-0669 \\
-0604 \\
-0669\end{array}$ & $\begin{array}{l}3 \\
1 \\
4 \\
1\end{array}$ & $\begin{array}{r}309 v \\
1100 v \\
27005 v \\
22100 v \\
103217 v\end{array}$ & $\begin{array}{l}0 \\
0 \\
0 \\
0 \\
0\end{array}$ & $\begin{array}{l}0 \\
0 \\
0 \\
0 \\
0\end{array}$ & $\begin{array}{l}0.3 V \\
0.3 V \\
0.0 V \\
0.1 V \\
0.4 V\end{array}$ & $\begin{array}{l}0.0 \\
0.0 \\
0.0 \\
0.0 \\
0.0\end{array}$ & $\begin{array}{l}\text { la } \\
\text { oA } \\
\text { UA } \\
\text { UA } \\
\text { UA }\end{array}$ & I \\
\hline $\begin{array}{l}356 \\
538 \\
336 \\
330 \\
530\end{array}$ & & $\begin{array}{l}6707 \\
6767 \\
0767 \\
6767 \\
0707\end{array}$ & $\begin{array}{l}-6064 \\
-0664 \\
-6609 \\
-1609 \\
-1644\end{array}$ & $\begin{array}{r}23 \\
1 \\
22 \\
1\end{array}$ & $\begin{array}{r}46460 v \\
236610 \mathrm{~V} \\
\text { s@scov } \\
460 \mathrm{~V} \\
19400 \mathrm{ur}\end{array}$ & $\begin{array}{l}0 \\
0 \\
0 \\
0 \\
0\end{array}$ & $\begin{array}{l}0 \\
0 \\
0 \\
0 \\
0\end{array}$ & $\begin{array}{l}3.34 \\
2.3 V \\
6.74 \\
0.04 \\
0.04\end{array}$ & $\begin{array}{l}0.0 \\
6.0 \\
6.0 \\
0.0 \\
0.0\end{array}$ & $\begin{array}{l}\text { CA } \\
\text { OA } \\
\text { OA } \\
\text { CA } \\
\text { UA }\end{array}$ & . \\
\hline $\begin{array}{l}556 \\
558 \\
558 \\
558 \\
538\end{array}$ & & $\begin{array}{l}0707 \\
6767 \\
0767 \\
6767 \\
0767\end{array}$ & $\begin{array}{l}-6004 \\
-6064 \\
-0669 \\
-0669 \\
-0609\end{array}$ & $\begin{array}{l}2 \\
7 \\
3 \\
5\end{array}$ & $\begin{array}{r}\text { ss3v } \\
3828 v \\
07350 v \\
34006 v \\
34200 v\end{array}$ & $\begin{array}{l}0 \\
0 \\
0 \\
0\end{array}$ & $\begin{array}{l}0 \\
0 \\
0 \\
0 \\
0\end{array}$ & $\begin{array}{l}6.3 V \\
4.0 v \\
6.1 V \\
10.4 V \\
1.0 V\end{array}$ & $\begin{array}{l}0.0 \\
0.0 \\
6.0 \\
0.0 \\
0.0\end{array}$ & $\begin{array}{l}C A \\
O A \\
O A \\
D A \\
\text { CA }\end{array}$ & $\begin{array}{l}E \\
E\end{array}$ \\
\hline $\begin{array}{l}550 \\
550 \\
550 \\
356 \\
556\end{array}$ & & $\begin{array}{l}6707 \\
6707 \\
0707 \\
0707 \\
0707\end{array}$ & $\begin{array}{l}-6664 \\
-6604 \\
=1669 \\
=0649 \\
=0064\end{array}$ & $\begin{array}{r}4 \\
10 \\
2 \\
2\end{array}$ & $\begin{array}{r}202400 V \\
32500 v \\
2234 V \\
11160 v \\
111040\end{array}$ & $\begin{array}{l}0 \\
0 \\
0 \\
0 \\
11\end{array}$ & $\begin{array}{l}0 \\
0 \\
0 \\
0 \\
0\end{array}$ & $\begin{array}{l}16.1 v \\
4.4 v \\
1.9 v \\
2 s .3 v \\
3.3 v\end{array}$ & $\begin{array}{l}0.0 \\
6.0 \\
6.0 \\
6.6 \\
0.0\end{array}$ & $\begin{array}{l}\text { T.A } \\
\text { DA } \\
\text { WA } \\
\text { OA } \\
\text { UA }\end{array}$ & $\overline{-}$ \\
\hline $\begin{array}{l}\text { 556 } \\
558 \\
\text { OLC } \\
\text { DLC }\end{array}$ & & $\begin{array}{l}6767 \\
6767 \\
6767 \\
0767\end{array}$ & $\begin{array}{l}-0669 \\
=6069 \\
=0469 \\
=0609 \\
=\end{array}$ & $\begin{array}{l}16 \\
14 \\
13 \\
0\end{array}$ & $\begin{array}{r}1346 V \\
349 V \\
27956 V \\
3061 V \\
6\end{array}$ & $\begin{array}{l}0 \\
0 \\
0 \\
0 \\
0\end{array}$ & $\begin{array}{l}0 \\
0 \\
30 \\
1 \\
0\end{array}$ & $\begin{array}{l}4.0 v \\
3.0 v \\
26.4 v \\
40.5 v \\
79.0 v\end{array}$ & $\begin{array}{l}0.0 \\
0.0 \\
0.0 \\
0.0 \\
0.0\end{array}$ & $\begin{array}{l}\text { OA } \\
\text { UA } \\
\text { us } \\
0 . \\
0 . \\
x x\end{array}$ & $=$ \\
\hline $\begin{array}{l}\text { DE } \\
\text { AU } \\
\text { OD } \\
\text { OL } \\
\text { OLG }\end{array}$ & DQ6 & $\begin{array}{l}6767 \\
6767 \\
6767 \\
0767\end{array}$ & $\begin{array}{l}-0069 \\
-6009 \\
-0069 \\
=0069 \\
=\end{array}$ & $\begin{array}{l}20 \\
23 \\
96 \\
0\end{array}$ & $\begin{array}{l}16098 v \\
16067 v \\
174235 \\
130904 \\
40024\end{array}$ & $\begin{array}{l}0 \\
0 \\
0 \\
0 \\
0\end{array}$ & $\begin{array}{c}30 \\
133 \\
143 \\
330 \\
0\end{array}$ & $\begin{array}{l}29.04 \\
33.74 \\
21.74 \\
23.24 \\
25.7 v\end{array}$ & $\begin{array}{l}0.0 \\
6.0 \\
0.0 \\
0.0 \\
0.0\end{array}$ & $\begin{array}{l}\text { Do } \\
\text { De } \\
W_{b} \\
w_{b} \\
c b\end{array}$ & $=$ \\
\hline
\end{tabular}


Rma SUMmanY on JnTOUT (mMk)

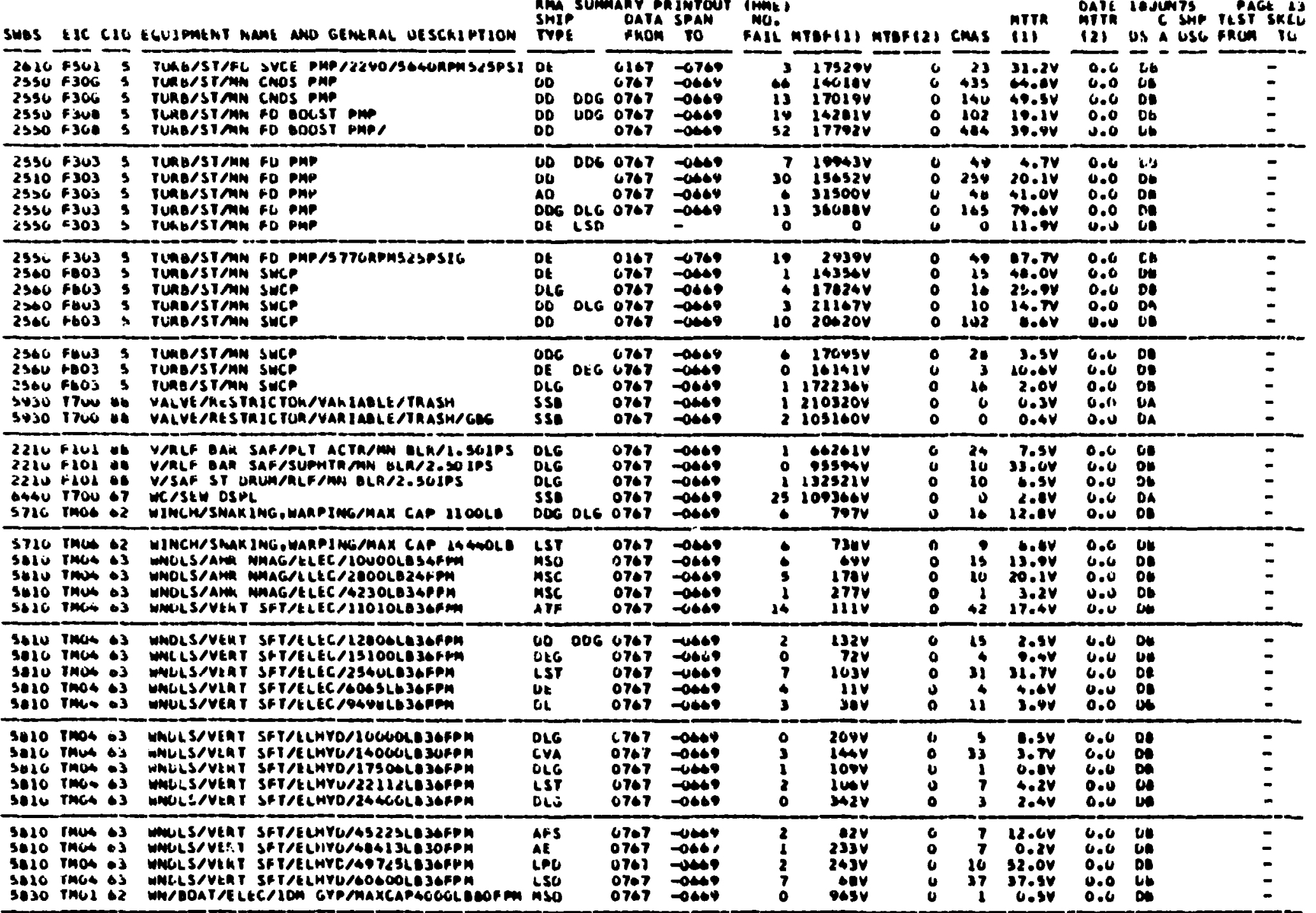




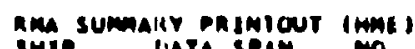

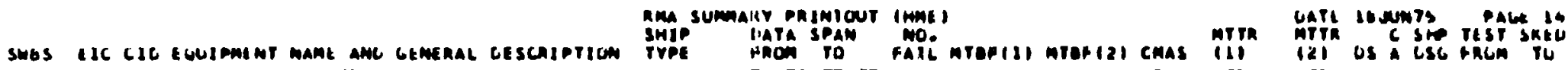

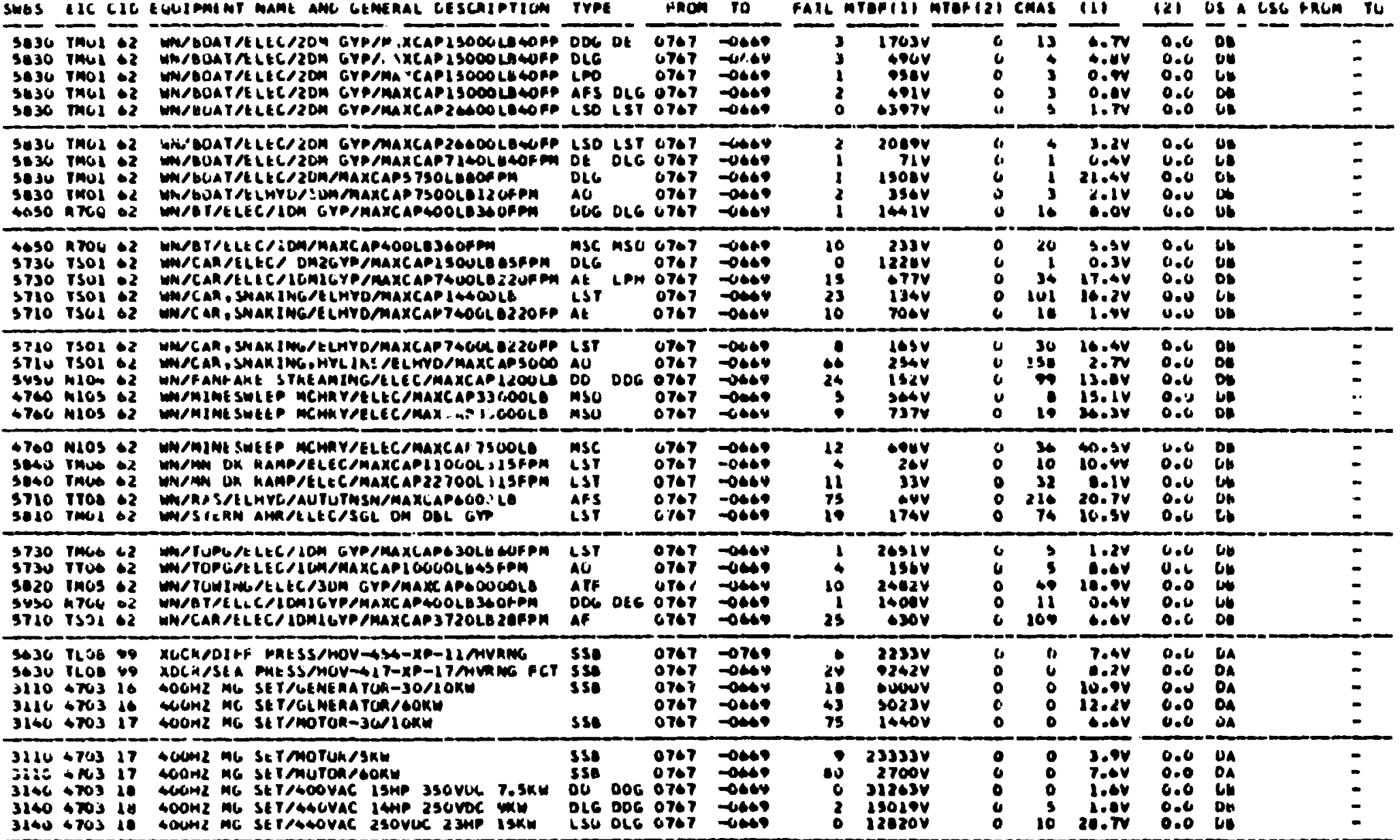




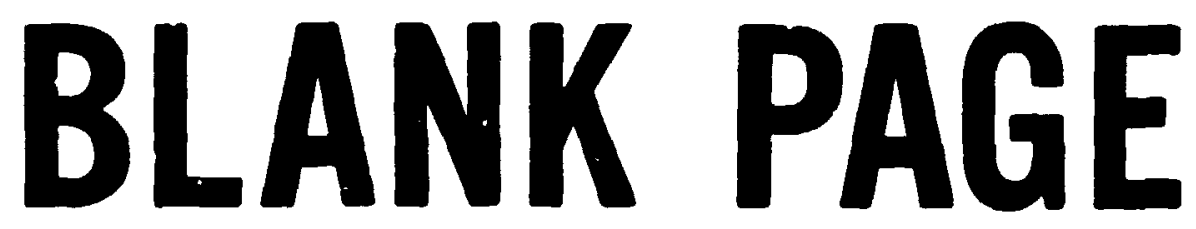


Appendix E

ROAE AIR DEVELOPHENT CEITER (RADC) DATA 
Table E.1. Components covered by the RADC Non-Electronic Reliability Notebook with possible application

in the nuclear industry

A.ccumulators

Hydraulic

Actuators

Linear, Electrical

Linear, Hydraulic

Linear, Hydraulic Servo

Liriea: Mechanical Driven

Linear, Pneumatic

Linear, Pneumatic Piston

Rolling Diaphragm

Rotary, General

Rotary, Electrical

Explosive

Antenras

General

Radar

Radio
Boards

Printed Circuit

Terminal

Circuit Protection Devices

Circuit Breaker

Circuit Breaker, 3-Pole

Electrical Surge Arrester, Spark Discharge

Fuse

Computer Peripheral Devices

Magnetic Cores

Magentic Tape Unit

Memory Disc

Memory Drum

Connections

Solder

Welded

Wire Wrap

Batteries

Rechargeable

Non-Rechargeable, One-Shot Connectors

Bearings

General

General

Circular

Ball

Coaxial

Needle

Roller

Rectangular

Sleeve

Spherical

Connector Pins

Counters, Fixed Rotational

Bellows

Diaphragms, Burst

General

Explosive

Drives, Constant Speed

Blowers \& Fans

General

Engines

Axial

Diesel

Gas Turbine

Centrifugal 
Table E.1 (continued)

Filters, Non-electric

Gaseous

Liquid

Fittings

General

Hydraulic

Quick Disconnect, Liquid

Swivel, Hydraulic

Gaskets \& Seals

Gaskets

O-Rings

Packing

Seals, General

Seals, Magnetic

Seals, Pressure

Gimbals

Hardware

Bushing

Brushes

Duct

Fuse Holder

Retaining Ring

Roller, Cargo Loading

Tallpipe

Tubing, Metal

Wasiner

Heat Exchangers

Heaters, Electr!cal

Hoses

General

Flexible Metal

Ignition Darts \& Explosives

Igniter, General

Igniter, Electric

Exp losive Bolt

Exflosive Motor

Explusive Squib

Explosive Switch

Explosive Timer

Squib Switch
Instruments

Ammeter

Galvanometer

Meter

Indicator

General

Air Pressure

Eng ine Torque

Fuel Quantity

Liquid Level

Magnetic Sensing Device

Rate of Flow

Tachometer

Temperature

Joints, Microwave, Rotary

Manifolds

Mechanisms, Power Transmittal

Arm

Axle

Bellcrank

Cam

Clutch, Friction

Elutch, Magnetic

Cord

Coupling

Crank

Drive Rod

Drum

Fàn Belt

Gear

Gearbox

Pulley

Shaft

Sprocket

Motors, Electrical

General

Irduction

Instrumentation

Fractional H. P., AC

2 H. P., AC

3 H. P., AC

5 H. P., AC

7.5 H. P., AC

10 H. P.. AC

20 H. P. . AC 
Table E.I (continued)

Motors, Electrical (Continued)

Hydraulic, DC

Permanent Magnet, DC

Servo, DC

Torque, DC

Motor-Generator Set

Generators

General

AC

$\mathrm{DC}$

Turbine Driven

Mounts, Resilient

Pumps

General

Boiler Feed

Centrifugal

Coolant

Fuel

Fuel Boost

Fuel Transfer, Hydraulic

Driven

Geroter Type

Hydraulic

Hydraulic, Manual

Hydraulic, Variable Delivery

Impeller

Oil

Oil Boost

Vacuum

Water

Compressor, Hydraulic Driven

Electric Driven

Engine Driven

Turbine Driven

Regulators

Fluid Tension

Fuel

Oxygen Demand

Pressure

Temperature
Relays

General

Armature

Contactor

Crystal Can, Latching

Crystal Can, Non-Latching

Latching, General

Latcning, Polarized

Non-latching, General

Reed

Thermal

Time Delay

Sensors

Horizontal

Torque

Slip Ring Assemblies

Solenoids

Switches

Centrifugal

Coaxial

Float, Liquid Level Indicator

Iimit

Pressure, General

Pressure, Hydraulic

Pushbutton

Reed

Rotary

Sensitive

Stepping

Thermostatic

Toggle

Waveguide

Synchros \& Resolvers

Synchro, General

Synchro Control Trar:former

Synchro Control Transmitter

Synchro Differential

Resolver 
Table E.1 (continted)

Tanks

Generai

Compressed Gas

Fuel

Fuel Cell

Liquid Oxygen

Metal Storage

Oil

Reservoir, Hydraulic

Thermocouples

Timers, Electromechanical

Transducers

General

Fluid Flow

Motional

Pressure

Tachometer Generator

Temperature

Iransmitters

Flow

Humidity

Pressure

Temperature

Transiormers, Variable

Valves

General

Ball

Butterfly

Check

Control

Clobe

Relief

Selector

Sequencer

Shut-Off

Solenoid

Freon, General

Fuel

Fuel, Check
Fuel, Float

Fuel, Gate

Fuel, Pressure Regulator

Fuel, Selector

Fur.1, Shut-Oŕf

Fuel, Solenoid

Hydraulic

Hydraulic, Ball

Hydraulic, Check

Hydraulic, Control

Hydraulic, Pressure

Regulator

Hydraulic, Relief

Hydraulic, Restrictor

Hydraulic, Sequencer

Hydraulic, Servo

Hydraulic, Shuttle

Hydraulic, Shut-Off

Hydraulic, Solenoid

Hydraulic, Spool, 4-iVay

Oil, General

Pneumatic

Pneumatíc, Bleed

Pneumatic, Check

Pneumatic, Control

Pneumatic, Pressure

Requlator

Pneumatic, Relief

Pneumatic, Selector

Pneumatic, Shut-Off

Pneumatic, Solenold

Water

Water, General

Water, Check 
Appendix 5

GOVERRTFNT/INDUSTRY DATA EXCHANGE PROGRAM (GIDEP) GENERIC CÔDES 
Table F.1. Major classifications of the GIDEF generic code

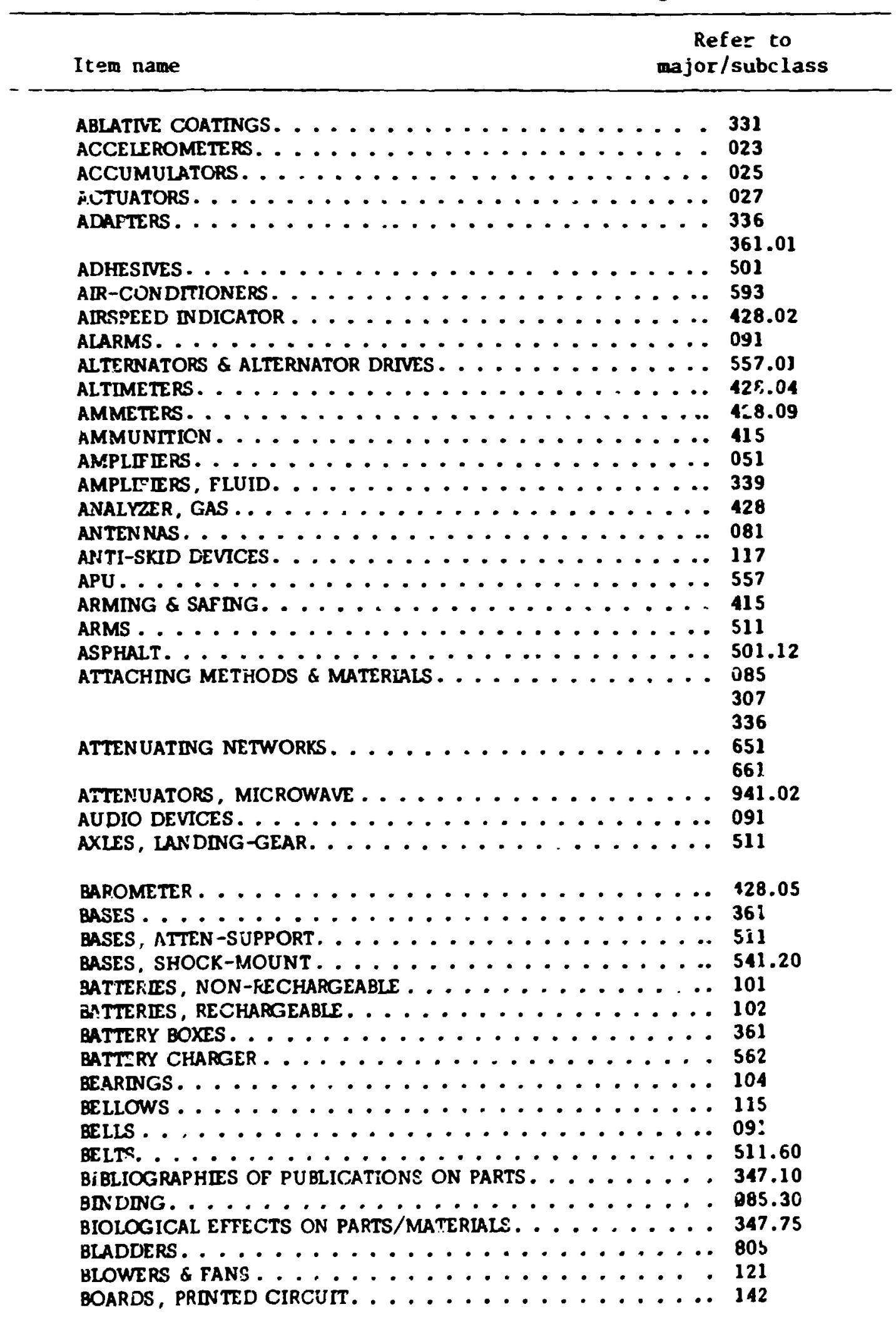


Table F.1 (rontinued)

$\begin{array}{cc}\text { Refer to } \\ \text { Item nane } & \text { wor/subcilass }\end{array}$

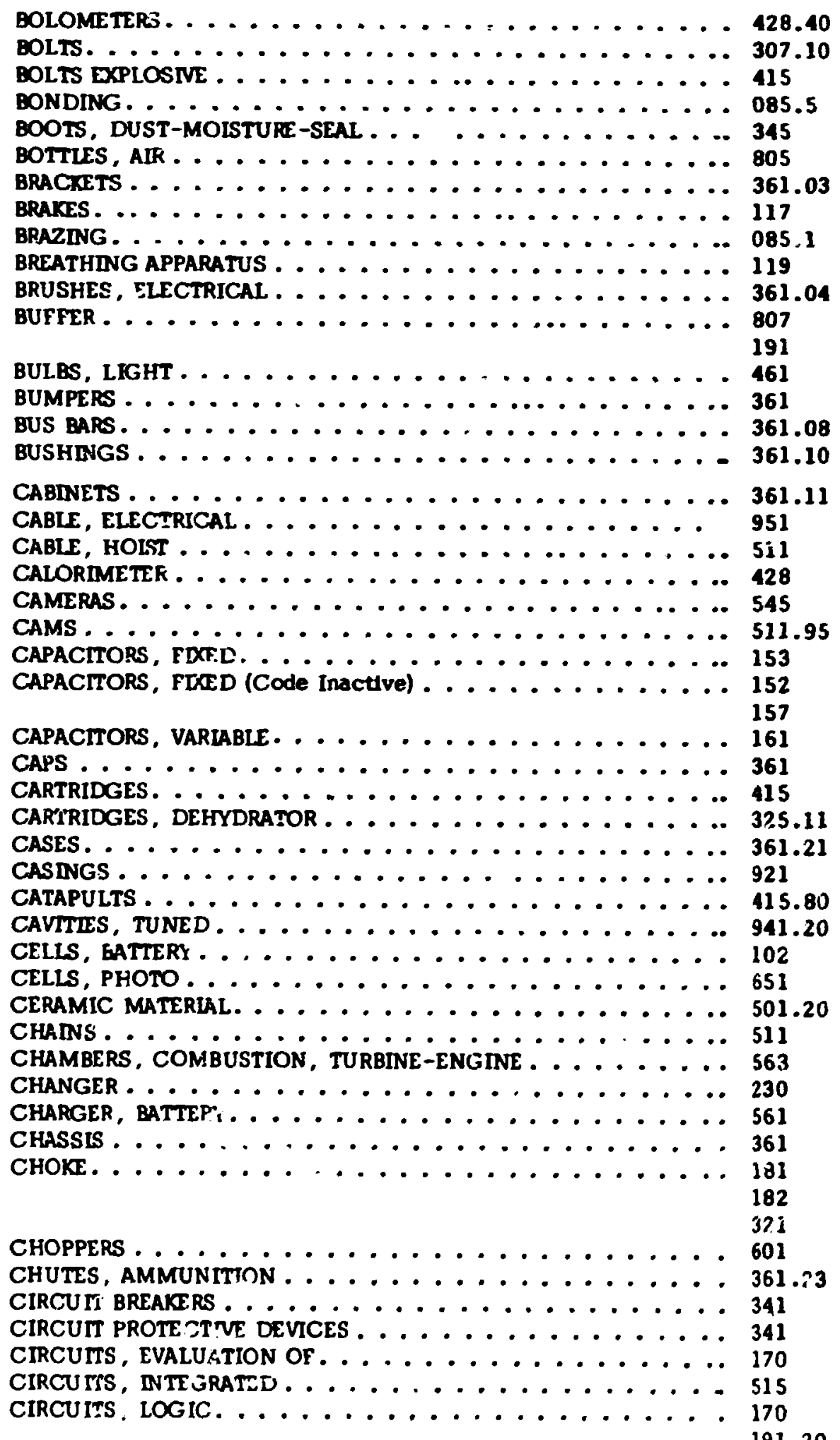


Table F.1 (continued)

\begin{tabular}{ll} 
Refer to \\
Item nave & major/subclass \\
\hline
\end{tabular}

CIRCUITS, MICRO. . . . ............... 515

¿IRCU ITS, PRINTED. . . . . . . . . . . . . . .. 142

CRCULATORS ...................... . . . 941.25

SIAMPS....................... 307.20

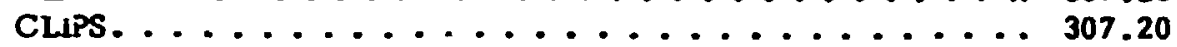

CLOCKS .............................. 811

CLUTCHES...................... 511.80

COATINGS. ................... 331

COAXIAL CABLE. . . . . . . . . . . . . . . 941

COCKS, DRARN. . . . . . . . . . . . . . . . .. 927

CORER ....................... 807

191

COIL FORMS. . . . . ............... . . 361.55

COIIS, RNDUCTANCE, ADJUSTABLE. . . . . . . . . .. 182

COILS, NDUCTANCE, FDED . . . . . . . . . . . 181

COMMUNICATIONS EQUIPMENT. .............817

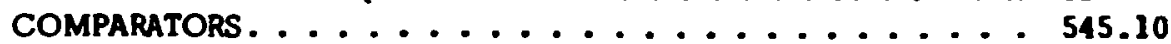

COMPASSES. ........................ 428.15

COMPATIBIITY OF MATERIALS REPORTS . . . . . . . 347.15

COMPRESSORS. ................... 575

COMPRESSORS, REFRIGERATION. ........... 593.20

COMPUTER \& RECORDNG ELEMENTS. . . . . . . . . 191

COMPUTER SOFTWARE. . . . . . . . . . . . . 195

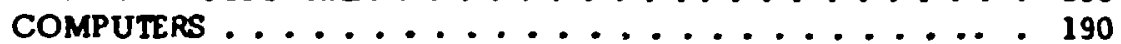

CONDITIONERS, SIGNAL. ................ 807

CONDUITS...................... 921

CONNECTIVE-LINKS. .................. 361.63

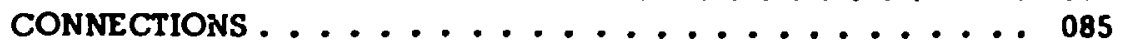

CONNECTORS, ELECTRICAL. ............... 201

CONNECTORS, HYL \& MECH. ............. 336

CONSOLES . . . .......................... 361

CONTACT-ASSYS, ELEC ................. 601

CONTACTS, ELECTRICAL . . . . . . . . . . . 361.12

CONTAINERS . . . . . . . . . . . . . . 347

CONTPOLS . . . . . .............. 428

CONIERTERS . .................. 230

CONVERTERS, NON ROTATING . ............. 2J0

CONVERTERS, ROTARY (ELEC) . . . . . . . . . . . 557.01

COOLERS \& COOLING SYSTEMS. . . . . . . . . ... 593

CORD-ASSYS ........................ . . . . . .

CORES, MEMORY ................... 191

CORK ........................ s01

CORROSION..................... 502

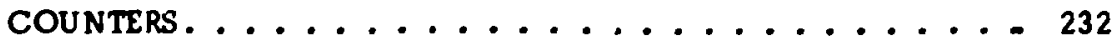

COUPLERS, ANTENNA. .................. 902

COUPLERS, DIRECTIONAL ................. 941 
Table F.1 (continued)

Refer to

Iteo nave

najor/subclass

COUPLINGS FLUID . ................ 336

COUPLINGS. MECHANICAL . . . . . . . . . . . 511.40

COUPLINGS, SHART, RIGID . . . . . . . . . . . 5? 51.40

COUPLINGS, WAVEGUIDE . . . . . . . . . . . 941.30

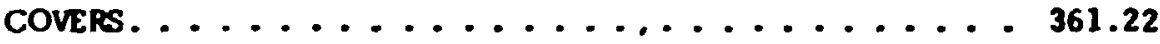

CRYOGENICS . . . . . . . . . . . . . . . . . 570

CRYOGENIC SYSTEMS . . . . . . . . . . . . . 593

CRYSTALS. . ................... 241

CRYSTAL TRANSDUCERS. . .............. 852

CYLINDERS, COMPRESSED-GAS. ........... 805.50

DAMPENERS . . . . . . . . . . . . . . . . 027

DECALCOMANLA ................. 411

DECODERS. .................... 807

191

DELAY LINES . . . . . . . . . . . . . . 271

DEMODULATORS. . . . . . . . . . . . . . . 807

DESSICANTS. . . . . . . . . . . . . . 501.35

DESTRUCT SYSTEMS. . . . . . . . . . . . . . 415.05

DETECTING-RANG NG-SETS. . . . . . . . . . . 428

DETECTORS . . . . . . . . . . . . . 852

DETONATORS . ...................... 415

DIAPHRAGMS, VALVE. . . . . . . . . . . . 927

DIFEUSERS, AIR . . . . . . . . . . . . . 428

DIODES ....................... 751

DIODES (Code Inactuve)................ 741

DIODES, LIGHT EMITTING . . . . . . . . . . . . . 751

DISCONNECTS ................. 336

DISCRIMINATORS, ELECTRICAL . . . . . . . . . 321

DISTRIBUTION BOXES . . . . . . . . . . . . 361

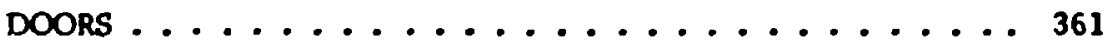

DOSIMETER . . . . . . . . . . . . . . . 543

DRAG-LINKS .................. 361

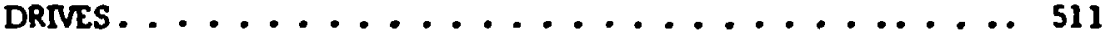

DRUM, COMPUTER .................. 191.50

DUCTS ...................... 361

921

DUPLEXERS . . . . . . . . . . . . . . . 807

817

DYNAMOTORS .................... 557.03

ETECTORS, FLUID \& GAS . . . . . . . . . . . . . . . 597

ELAPSED TIME INDICATORS . . . . . . . . . . . 811.05

ELECTRO EXPLOSIVE DEVICES . . . . . . . . . . . 415 
Table F.1 (continued)

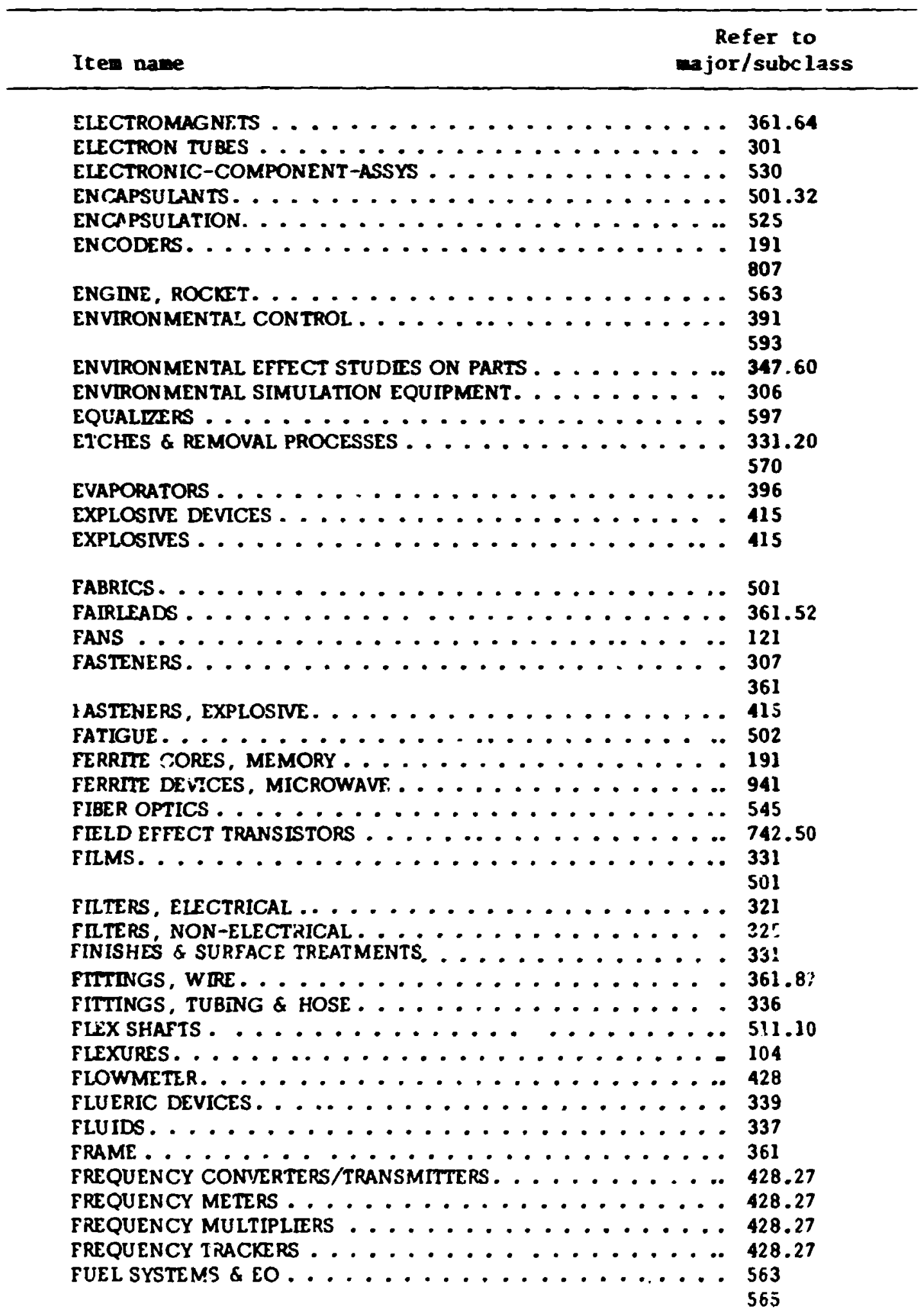


Table F.1 (continued)

$\begin{array}{cc}\text { Iten name } & \text { Refer to } \\ \text { najor/subclass }\end{array}$

FUSEHOLDERS ....................... 361.16

FUSES \& CIRCUIT PROTECTIVE DEVICES . . . . . . . . . 341

FUSES, HYDRAULIC ................... 239

FUSES, MMPACT. ....................... 415.80

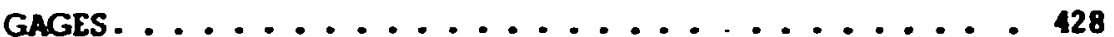

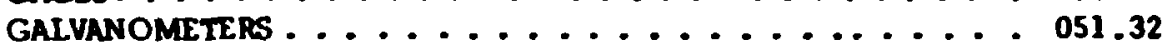

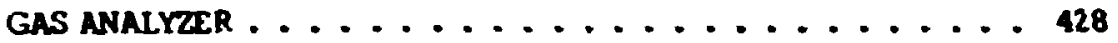

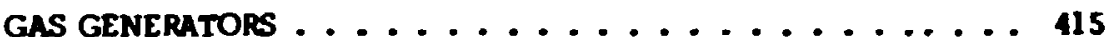

GASIATS \& SEALS .................. 345

GATES, ELECTRONIC. ................. 791.05

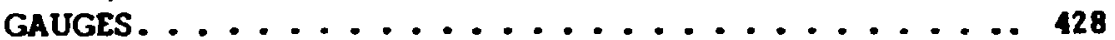

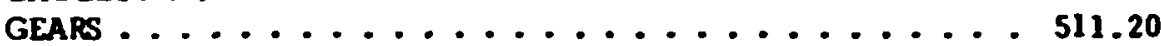

GENERAL TECHNICAL DATA .............. 34 .

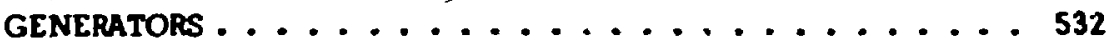

GENERATORS, SIGNAL................. 555

GIMBALS, ROCKET MOUNTING. ............. 541

GOVERNORS ..................... 597

GROMMETS ..................... 361.52

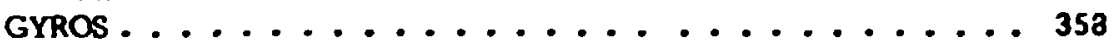

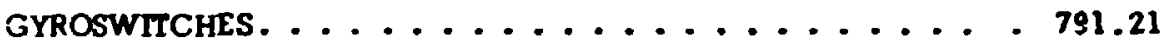

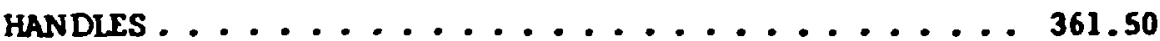

HARDWARE (Mechanical \& Electro Mechanlcal) . . . . . . . 361

HARDWARE IN SPACE, PRCJLEMS OF. ............ 347.95

HARMONIC DRIVES .................. 511

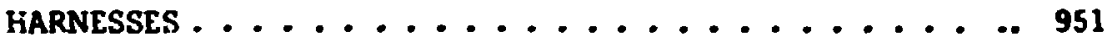

HAZARLOUS GAS ANALYZER. ................428

HEADS, ROTARY-WING ..................... 511

HEADS, SOUND-RECORDER ............... 191

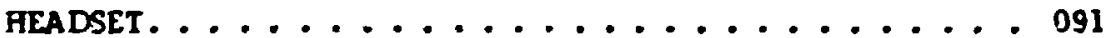

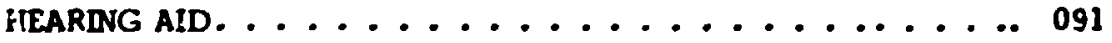

HEAT EXCHANGERS ...................... 386

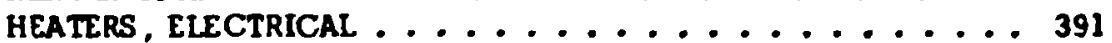

HZAT SDNKS..................... 361.57

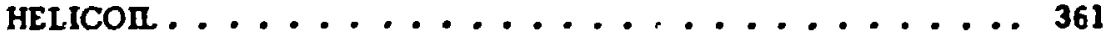

HELIUM SYSTEMS.................. 805

337.32

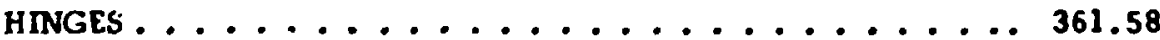

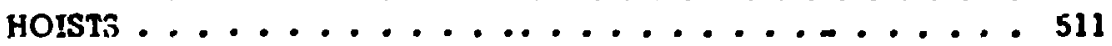

HOLDERS, LAMP \& FUSE. ................ 361.16

HONEYCOMB, STRUCTURAL ................ 501

502

HOOKS............................ 307.10

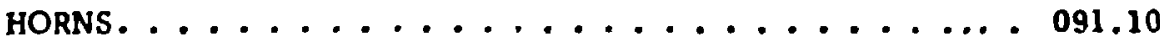

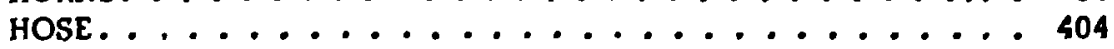

921 
Table F. I (continued)

Item name

Refer to

major/subclass

HOUSINGS. ................... 361.21

HUBS ....................... 361.59

HUMAN ENGINEERING OF PARTS/CCMPONENTS. . . . . 347.90

HYDFAULIC MOTORS AND PUMPS. . . . . . . . . . . 575

HYLRAULIC SYSTENS . . . . . . . . . . . . 025

027

337

HYDROGER EMBRITTLEMENT. . . . . . . . . . . . 331

502

HYDROPHONES .................. 852.73

IDENTIFICATION DEVICES \& METHODS . . . . . . . . 411

IGNITION PARTS \& EXPLOSIVES . . . . . . . . . . . 415

ILLUMINATIO $: \ldots \ldots \ldots \ldots \ldots \ldots \ldots$

IN DEXES OF PUBLICATIONS ON PARTS. . . . . . . 347.10

INDICATING EQUTPMENT . . . . . . . . . . . . . . 809

INDICATOR, EIAPSED TIME . . . . . . . . . . 811.05

INDICITOR, LAMFS ................ 461

INDICATOR, REVOLUTIONS .............. 232

INDICATORS. . . . . . . . . . . . . . . 428

INDUCTANCE COILS, ADJUSTABLE. . . . . . . . . 182

INDUCTANCE COIS, FDED . . . . . . . . . . . 181

INDUCTORS ...................... 181

182

INFRAREL EQ (SENSING) . . . . . . . . . . . 852

INFRLEED TESTING. ................ 556.30

INITATORS ......................... 5

INSERTS ..................... 361

INSTRUMENTS, ACCELEROMETERS . . . . . . . . 023

INSTRUMENTS AND CONTROLS. . . . . . . . . . . 428

INSTRUMENTS, COUNTERS ............... 232

INSTRUMENTS, NUCLEAR ENERGY. ........... 428.55

INSTRUMENTS, TIMERS \& PROGRAMMERS. ........811

INSULATION, FINISHES ............... 311

INJULATION, HARDWARE . ............. 361

INSULATION, MATERIALS . ............. 501

NTEGRATED CIRCUITS ............... 515

INTEGRATION, IARGE SCALE ............ 515

INTERCOMMUNICATION-STATIONS . . . . . . . . . 091

INTERCONNECTIF'S-BOXTS. .............. 361.25

INTERFEROMETERS, ELECTRICAL. ........... 545

INTERPHONE SYSTEMS ............... 091

INTERVALOMETLIS. ................. 557

INVERTERE. . ................... 230

ISOLATCR, VIBRATION .............. 541

ISOLATORS, RF-REFLECIIOHJ. . . . . . . . . . 761.10

JACK ...................... 201

361 
Table F.1 (continued)

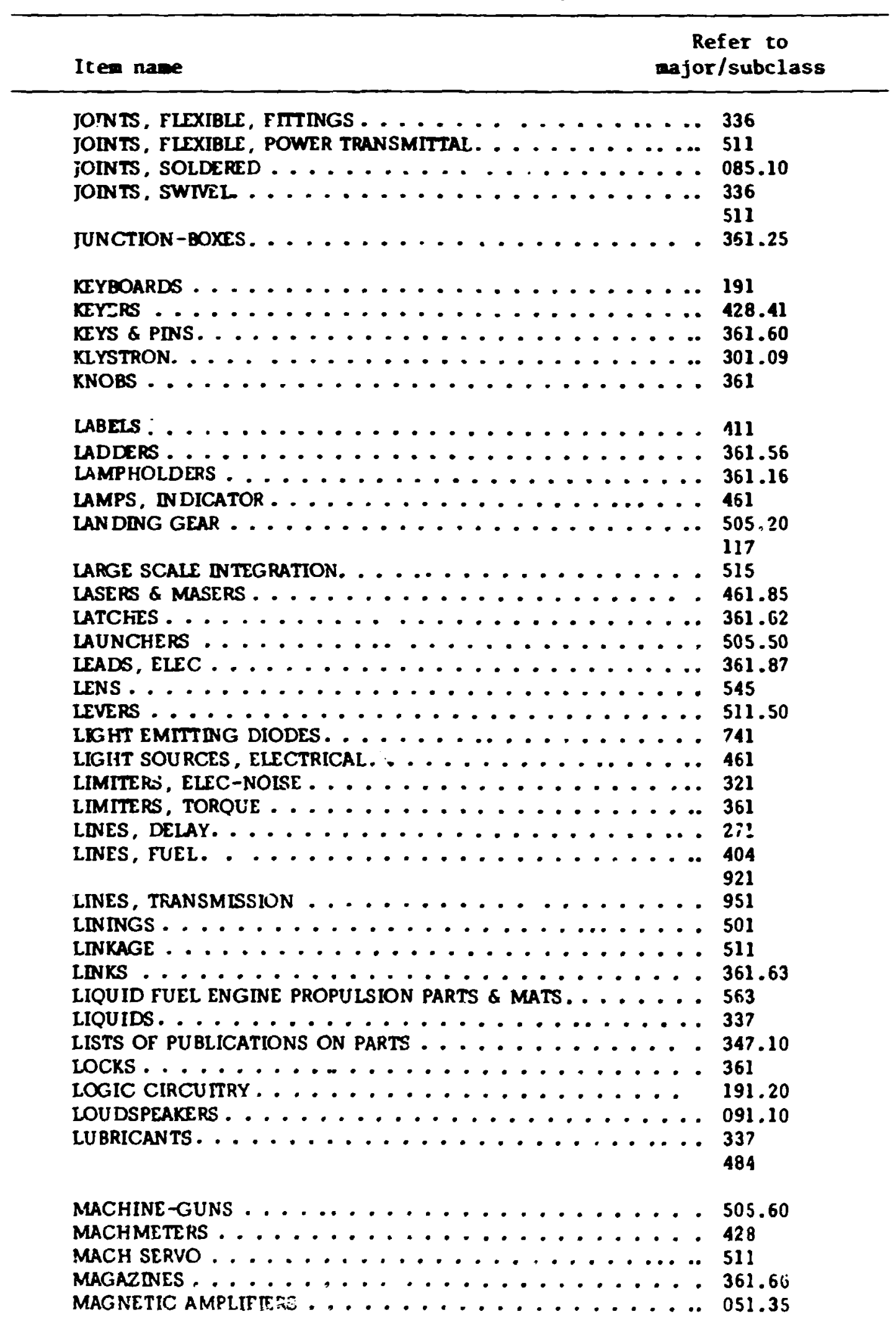


Table F.1 (continued)

\begin{tabular}{cc}
\hline Item name & $\begin{array}{c}\text { Refer to } \\
\text { major/subclass }\end{array}$ \\
\hline
\end{tabular}

MAGNETIC-DRUMS .................... 191.50

MAGNETIC RECORDING WIRE ............... 191

MAGNETRONS ...................... 301

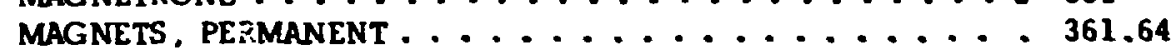

MANIFOLDS. ......................... 563

MIAN UFACTURIJG PROCESSES AND TECHNIQUES . . . . . . 570

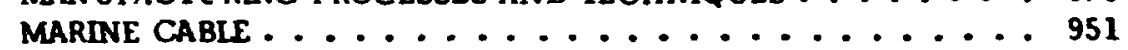

MASERS \& LASERS .................... 461.85

MATERIAL REPORTS, COMPATIBILITY . . . . . . . . 347.15

MATERLALS, METALLIC ................. 502

MATERALS, NON-METALLIC .............. 501

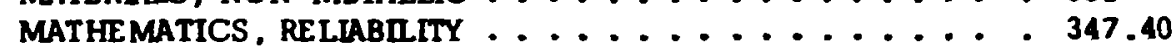

MEASURING EQUIPMENT ................. 809

MECHANICAL ASSE MBLIES ............... 505

MECHANISMS, POWER TRANSMITTAL ........... 511

MEMORY ....................... 191

METAL FORMING \& MACHINE PROCESSES. . . . . . . . 570

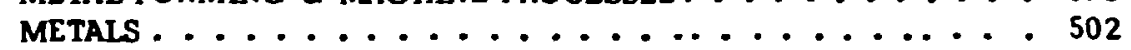

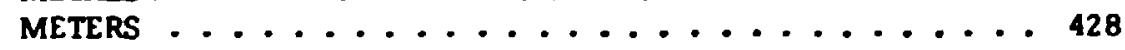

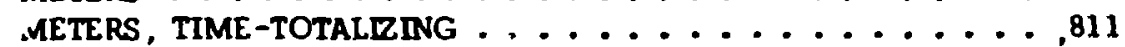

MICROELECTRONIC CIRCUITS .............. 515

MICROPHONE ......................... 091.20

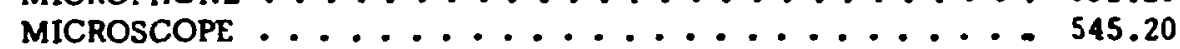

MICROSWTTCHES ........................ 791

MICROWAVE EQ., OSCILLATORS .............. 555

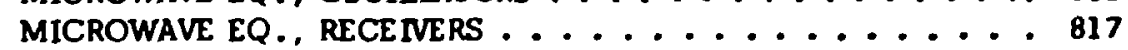

MICROWAVE EQ., SIGNAL GENERATORS . . . . . . . . 555

MICROWAVE EQ., T RANSCEIVERS . . . . . . . . . . . 817

MICROWAVE EQ., TRANSMITTERS . . . . . . . . . . 817

MICROWAVE EQ., VIAVEGUIDE ................ 941

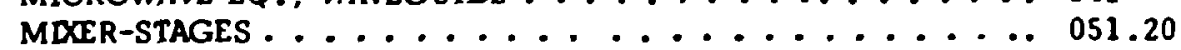

MODULAR PACKAGING TECHNIQUES ............ 501

525

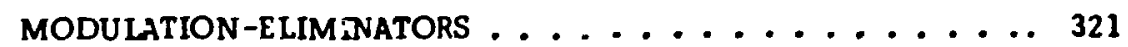

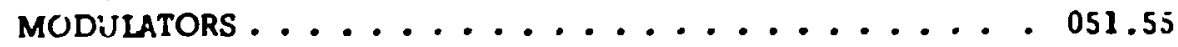

MODULES (other than 515) ................. 530

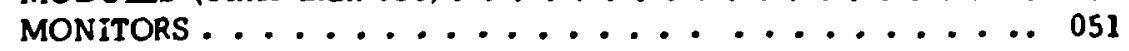

MOTORS, MOTOR GENERATORS ............... 532

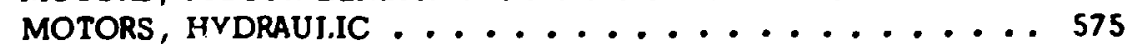

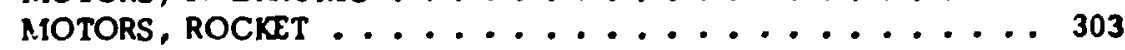

MOTOR PARTS, ROCKIT ................ . . 565

MOUNTING OF PARTS ................ 347.23

MOUNTS, RESILIENT (Shock \& Vib isolation). . . . . . . . 541

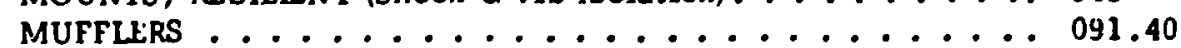

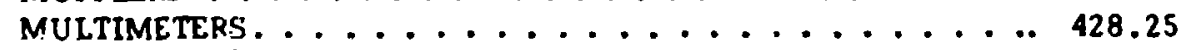

MULTI-PART/COMPONENT REPORTS . . . . . . . . . 347.15

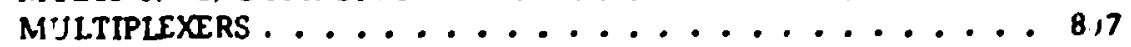

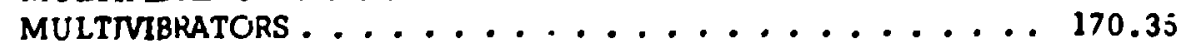


Table F.1 (continued)

\begin{tabular}{cc} 
Refer to \\
Item name & major/subclass \\
\hline
\end{tabular}

NETWORKS, CIRCUITS. . . . . . . . . . . . 170

NETWORKS, DELAY LINES . . . . . . . . . . . 271.4

NETNORKS, MODULES ................ 530

NEW MISSIIE/AEROSPACE SAFETY HAZARDS. . . . 347.97

NIXIE TUBES. . . . . . . . . . . . . . . . . 301

NOZZLES ......................... 563

NUCLEAR ENERGY AND MEASURING EQUIPMENT . . . . . . 545

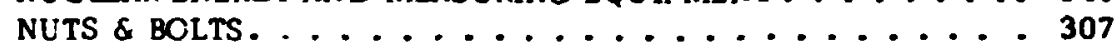

"O" RINGS . . . . . . . . . . . . . . . . 345.50

OCEANOGRAPHIC STUDIES ............ $34^{\circ} .45$

OCEANOGRAPHY. ................. 34745

OPTICAL DE VICES \& CAMERAS. . . . . . . . . . 545

OPTICALLY COUPLED ISOLATORS. . . . . . .... 743.90

ORDNANCE DEVICES ................ 415

OSCILLATORS \& S!GNAL GENERATORS . . . . . . . . . 555

OSCILLOGRAPHS. ................ 587

OSCILLOSCOPES. ................. 556

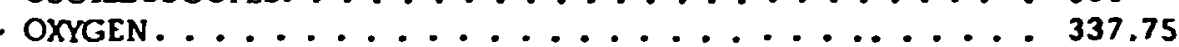

PACKAGING CONTAINERS .............. 347.23

525

PAINTS \& APPLIED COATINGS . . . . . . . . . . . 331

PANELS. .................... 361.71

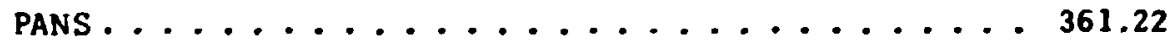

PARTS PROCUREMENT SPECIFICATIONS \& PLANS . . . . . 347.55

PARTS TESTING EQU IPMENT . . . . . . . . . . . . . $540^{\circ}$

PARTS USE, MOUNTING \& APPLICATION DATA. . . . . 347.23

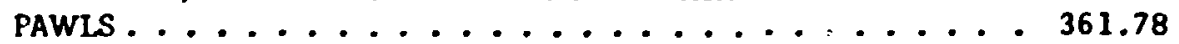

PERISCOPE .................. 545.30

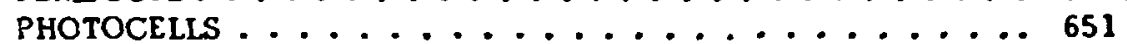

PHOTOGRAPHIC EQUIPMENT. . . . . . . . . . . 545

PINS \& KEYS ................... 361.60

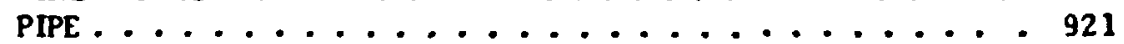

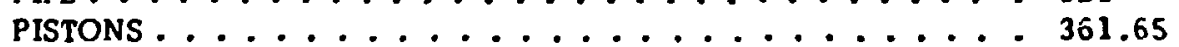

PITUT-TUBES. . . . . . . . . . . . . 921

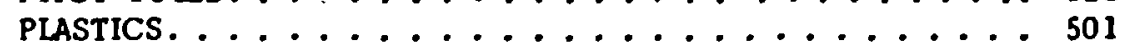

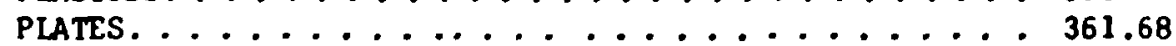

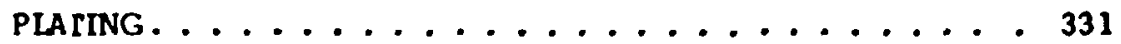

PLUGS, MECHANICAL ................ 361

PLUGS, IGHTTOR. .............. 415.40

PLUGS, ELECTRICAL ...................... 201

POLYMERS .......................... 501

POTENTIOMETERS .................. 661

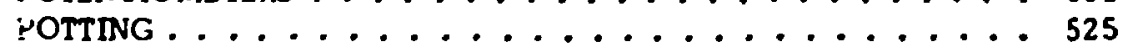

POTTING COMPOUNDS ................. 501.32

POW DER METALS (PIM) ............... 502

POWER SUPPLIES, ELECTRICAL, NON-ROTATING...... 561 
Table F.1 (continued)

POWER SUPPLIES, ELEC, NON-ROTATING (Inactv) . . . . . 562

POWER SUPPLIES, ELECTRICAL ROTATING. . . . . . . . 532

POWER TRANSISTORS. ................ 742.20

PRESSURE SWITCHES . . . . . . . . . . . . 791

PRESSURE TRANSDUCER ............... 352.5

SRESSURE VESSELS. . . . . . . . . . . . . 805

PREVALVE. . . . . . . . . . . . . . . . 927

PRIMA-CORDS.................. 415

PRIMERS .................... 331

PRINTED CIRCUIT BOARDE ............... 142

PROBES ...................... . 852

PROBLEMS OF HARDWARE IN SFACE. . . . . . . . . 347.95

PROCESSING (Mfg. Processes \& Techniques). . . . . . . . 085

PROCUREMENT SPECIFICATIONS, GENERAL . . . . . . 347.55

PROGRAM PLANS AND Q.A. OF PARTS. ......... 347.25

PROGRAMS, COMPUTER ............... 195

PROGRAMMERS.................. 811

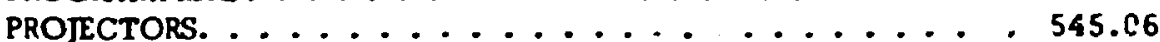

PROJECTORS, SONAR. .............. 428.73

PROJECTORS, TARGET-COURSE. ........... 428.15

PROPELLANTS ................... 563

PROPULCTON PARTS \& MATLS, LIQUID FUEL ENGS. . . . . . 563

PROPULSION PARTS \& MATLS, SOLID FUEL ENGS . . . . 565

PROTECTIVE COATINGS ............... 331

PROTECTIVE CLOTHING ............... 574

PROTECTIVE DEVICES, CIRCUIT ............. 34]

PUBLICATIONS ON PARTE, INDEX ON ........... 347.19

PULLEYS ...................... 511.90

PULSE FORMING NETWORKS ............... 321

PUMPS \& HYDRAULIC MOTORS ............ 575

PUSHBUTTON SWITCH . ................ 791

PRYOMETER ..................... 545

PYROTECHNICS ................... 415

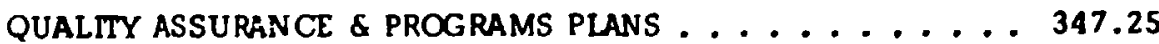

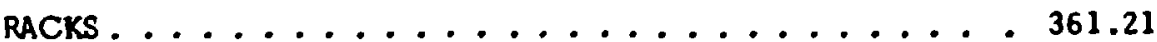

RADAR, ANTENNAS .................... 081

RADAR, SETS ................... 817

RADAR, WAVEGUIDE. .................. 947

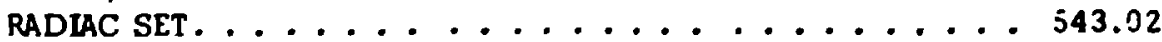


Table F.1 (continued)

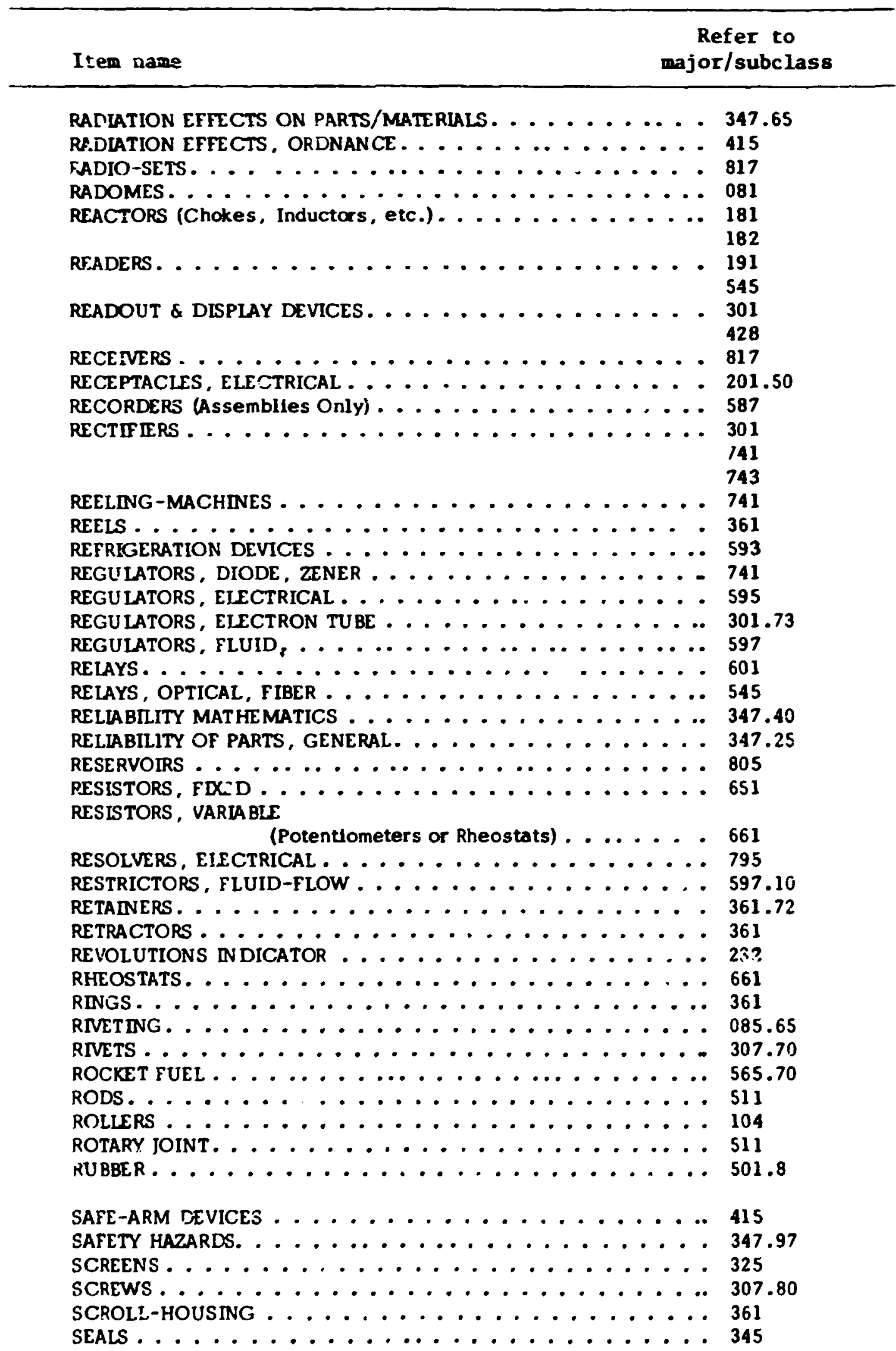


Table F.1 (continued)

Item nage $\quad \begin{gathered}\text { Refer to } \\ \text { major/subclass }\end{gathered}$

SELECTOR MODULATION . . . . . . . . . . . . 807

SEMICONDUCTORS, DIODES .............. 731

SEMICON DUCTOPS, DIODE (Code Inactive) . . . . . . 751

SEMICONDUCTORS, NNTEGRATED CIRCUTTS. . . . . . . . 515

S:MICON DUCTORS, SPECIAL TYFES OF. . ......... 743

S.MICONDUCTORS, SPECIAL TMPES OF (Inactv) ....... 753

SEMICONDUCTORS, TRANSISTORS . . . . . . . . . . . 742

SEMIICON Tr.jCTORS, TRANSISTORS (Inactive) . . . . . . 752

SENSORS ..................... 852

SEPARATORS .................... 339

SERVOCYLINDERS ................ 027

SERVOMECHANISMS. ................ 795

SERVOVRLVES. . ............... 927

SERVOS, ELECTRICAL. ............... 532

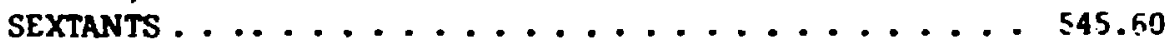

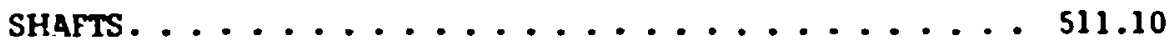

SHIELDS \& SHIELDING ................ 761

SHIMS \& SPACERS ................. 361.74

SHOCK ABSORBERS .................. 541.20

SIGHTS ......................... 545

SIGNAL GENERATORS ................. . . 555

SIIICON CONTROLLED RECTIFIERS . . . . . . . . . . 741.30

SIMULATION EQUIPMENI, ENVIRONMENTAL. . . . . . 306

SIRENS. ..................... 091.10

"LEEVING .................... . . 921

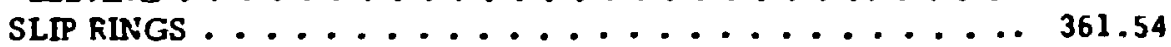

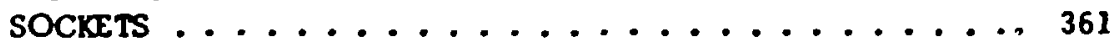

SOFTWARE, COMPUTER ................. 195

SOLAR CELLS. . . . . . . . . . . . . . 102.60

SOLDERING . ........................ 085

SOLENOLDS. ....................... 771

SOLID FUEL PRCPULSION PARTS \& MATERIALS . . . . . . 565

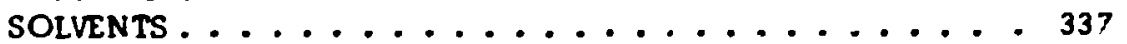

SPACERS \& SHIMS ................ 361.74

SPEEDOMETERS .................. 428

852

SPIDFRS. .................... 511

SPKINGS ..................... 361.77

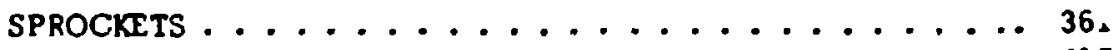

SQUIBS ..................... . . 415

STABILIZATION, GRAVITY ............... 358

STABLLIERS, ROTARY-WING ............ 505.80

STANLESS STEEL. ................. 502

STAINS \& PENETRANTS ................. 331

STAPLES . . . . . . . . . . . . . . . . . . 307.90

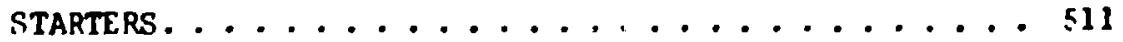

532

STOPS, ELEC .................... $7:$. .

STRAINERS .................. 325

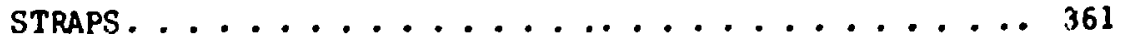

STRDBE LIG: T. . . . . . . . . . . . . .. 461

SUPPORTS. ....................... 361.78 
Table F.1 (continued)

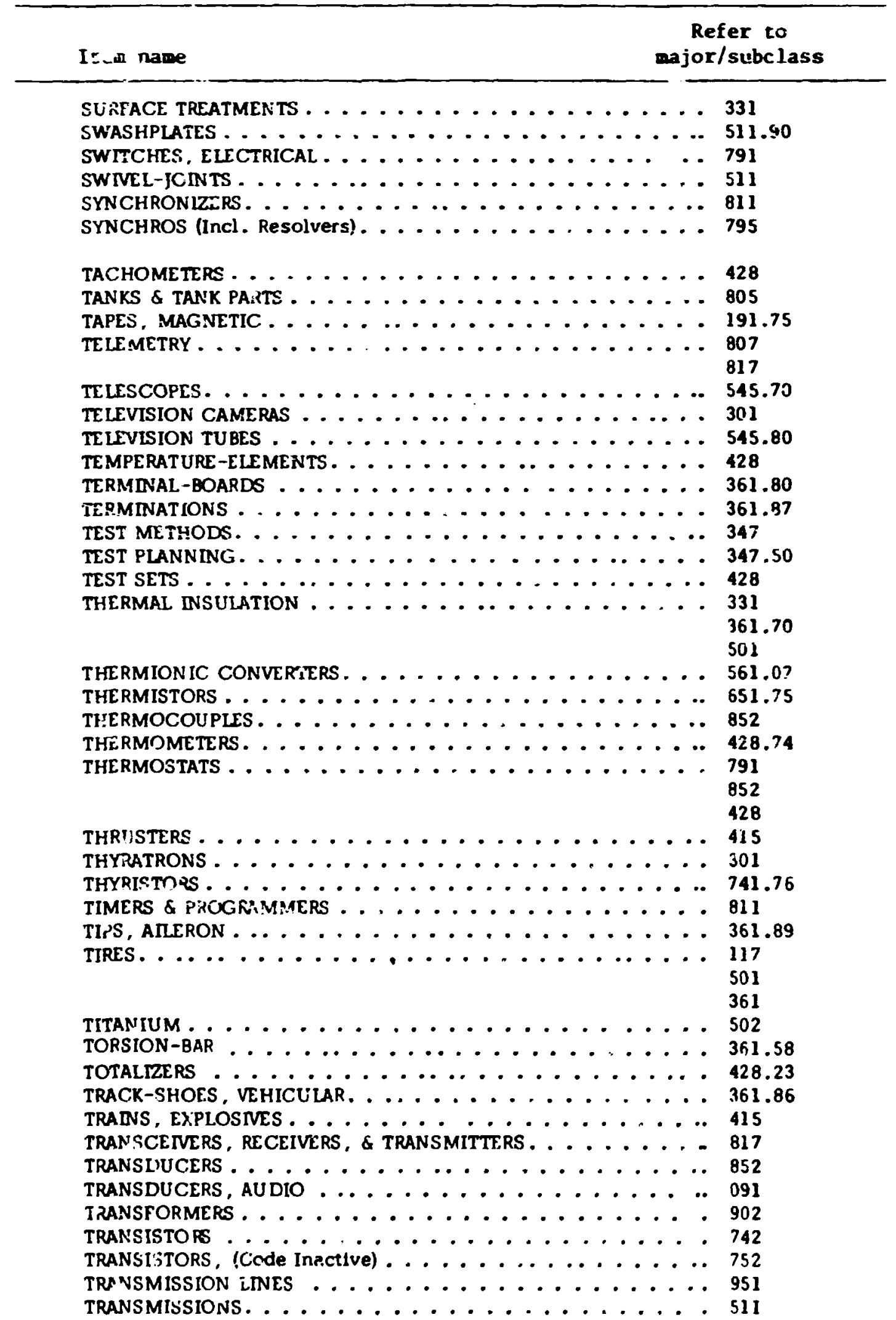


Table F.1 (continued)

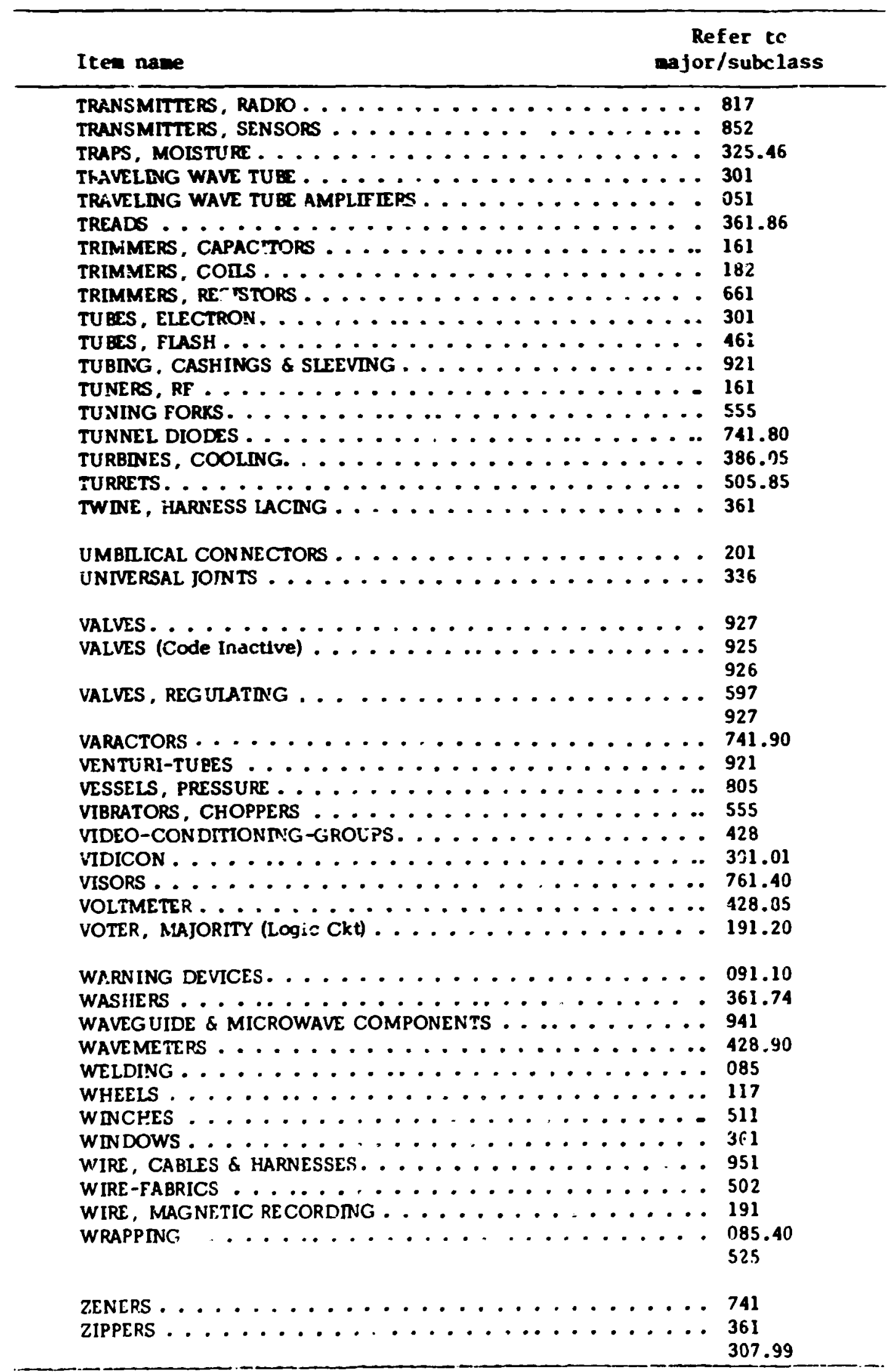

